US Army Corps of Engineers ${ }_{\circledast}$

Engineer Research and

Development Center

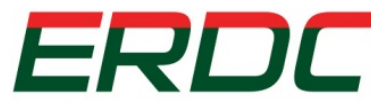

INNOVATIVE SOLUTIONS for a safer, better world

\title{
Feasibility Study of Food Waste Co-Digestion at U.S. Army Installations
}

Stephen D. Cosper, Dominique S. Gilbert, Irene E. MacAllister,

March 2017

M. Zillur Rahman, Jonathan Ricketts, Steven R. Rock,

Angela B. Urban, Alex W. Lan, and Giselle Rodriguez

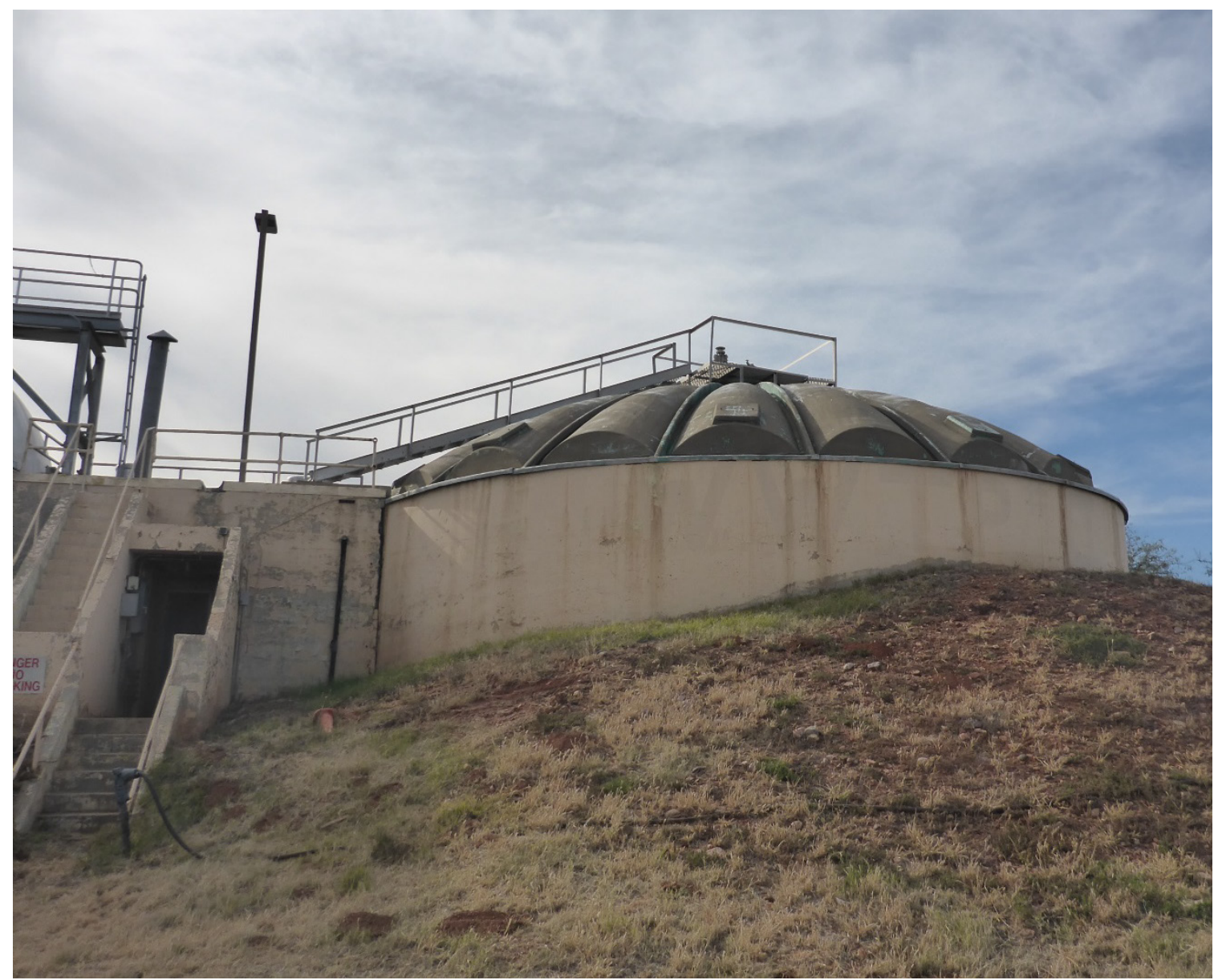


The U.S. Army Engineer Research and Development Center (ERDC) solves the nation's toughest engineering and environmental challenges. ERDC develops innovative solutions in civil and military engineering, geospatial sciences, water resources, and environmental sciences for the Army, the Department of Defense, civilian agencies, and our nation's public good. Find out more at www.erdc.usace.army.mil.

To search for other technical reports published by ERDC, visit the ERDC online library at http://acwc.sdp.sirsi.net/client/default. 


\section{Feasibility Study of Food Waste Co-Digestion at U.S. Army Installations}

Stephen D. Cosper, Dominique S. Gilbert, Irene E. MacAllister, M. Zillur Rahman, Angela B. Urban, and Giselle Rodriguez

Construction Engineering Research Laboratory

U.S. Army Engineer Research and Development Center 2902 Newmark Drive

Champaign, IL 61822

Jonathan Ricketts, Steven R. Rock, and Alex W. Lan

U.S. Environmental Protection Agency, Office of Research and Development 1200 Pennsylvania Avenue, NW 8101R

Washington, DC 20460

Final report

Approved for public release; distribution is unlimited.

Prepared for Assistant Secretary of the Army for Installations, Energy and Environment 110 Army Pentagon

Washington, DC 20314-1000

Under Project No. 455592, "EPA Net Zero Project Support” 


\section{Abstract}

Army Net Zero is a comprehensive approach to preserve natural resources by focusing on energy, water, and waste at Army installations. Army Directive 2014-02, "Net Zero Installations Policy" set policy and assigned responsibility to strive toward Net Zero at all Army installations, wherever fiscally responsible. As part of its greater vision of strategic sustainability, Fort Huachuca, Arizona, seeks to meet Army Net Zero objectives.

The Wastewater Treatment Plant (WWTP) at Fort Huachuca is the focus of the net zero waste project discussed here. The U.S. Army Engineer Research and Development Center-Construction Engineering Research Laboratory (ERDC-CERL), with collaboration from the U.S. Environmental Protection Agency, designed a study to evaluate the feasibility of food waste co-digestion at Fort Huachuca. The study was designed to (1) reduce the amount of organic material going to landfill, (2) reduce greenhouse gas emissions, and (3) produce renewable energy. From this work, team members concluded that co-digestion of food and biosolids would be a win-win scenario for Fort Huachuca because it would help eliminate the largest part of the waste stream (food), reduce biosolids disposal costs, and generate power for operating the installation's WWTP.

DISCLAIMER: The contents of this report are not to be used for advertising, publication, or promotional purposes. Citation of trade names does not constitute an official endorsement or approval of the use of such commercial products. All product names and trademarks cited are the property of their respective owners. The findings of this report are not to be construed as an official Department of the Army position unless so designated by other authorized documents. 


\section{Contents}

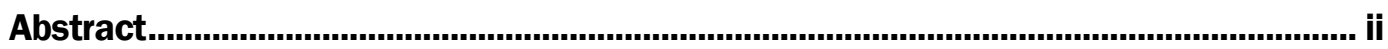

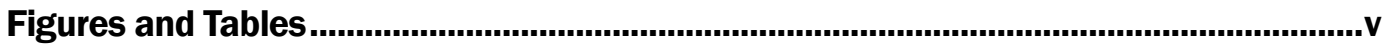

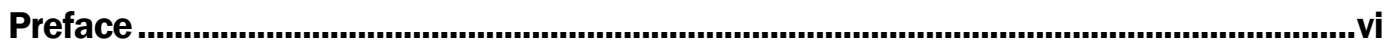

Unit Conversion Factors..................................................................................................vii

Abbreviations.................................................................................................................viii

1 Introduction ............................................................................................................ 1

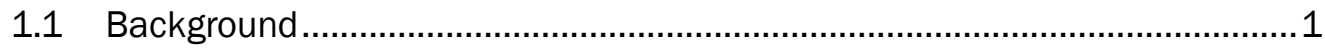

1.1.1 Army Net Zero Initiative ......................................................................... 1

1.1.2 Energy, water, and waste interconnections ...................................................... 2

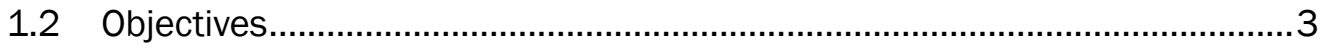

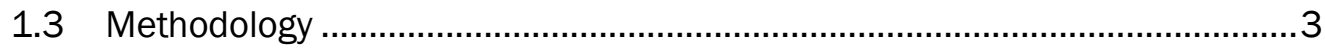

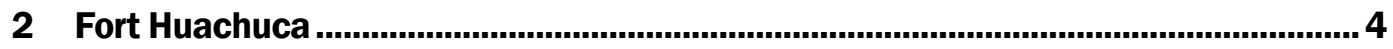

2.1 Overview of the installation..................................................................... 4

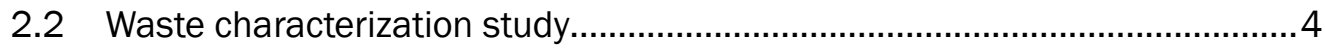

3 Fort Huachuca's Wastewater Treatment Plant......................................................... 7

3.1 History and infrastructure .................................................................... 7

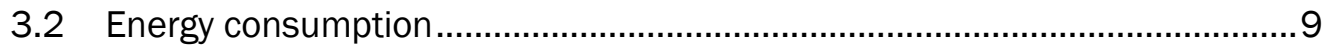

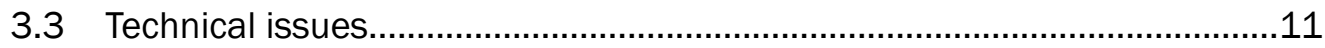

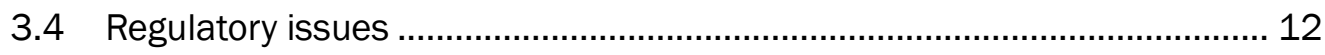

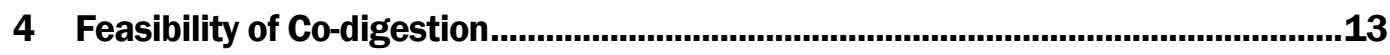

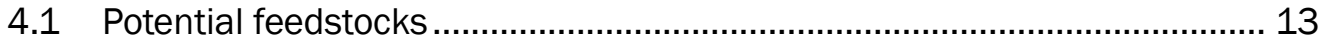

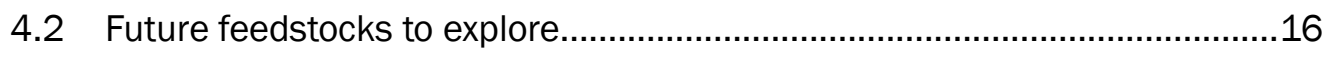

4.3 Digester feed mixtures ........................................................................16

4.3.1 Handling the high volume of waste-activated sludge ........................................ 16

4.3.2 Different anaerobic digester systems........................................................... 16

4.3.3 Digester inputs ...................................................................................... 17

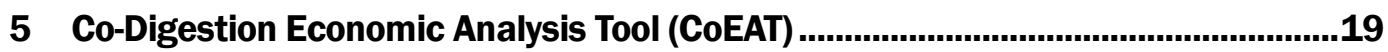

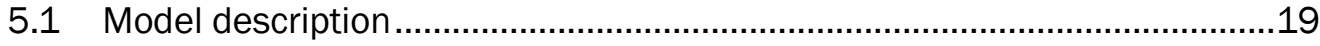

5.2 Modeling food waste AD scenarios .........................................................21

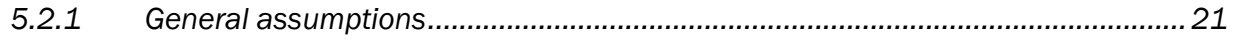

5.2.2 Scenario 1-6 assumptions......................................................................... 21

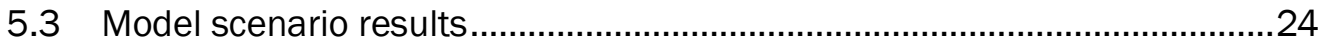

5.4 Fort Huachuca model conclusions ....................................................... 26

6 Proposed Investments for Potential Co-Digestion Operation................................31 


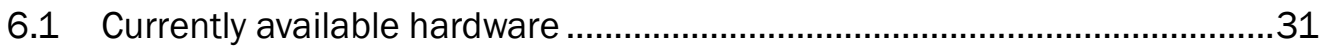

6.2 Investment considerations for current system ....................................... 33

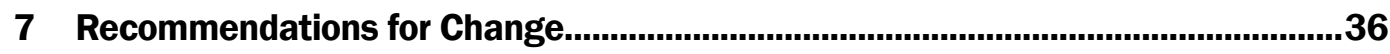

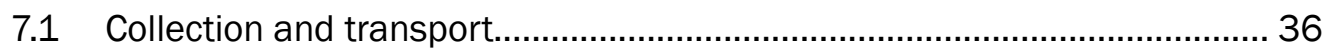

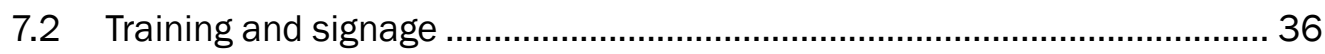

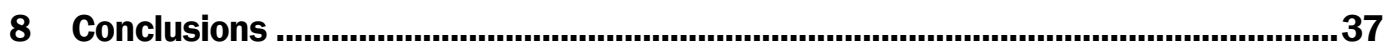

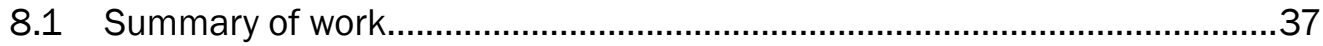

8.2 Integration of Army Net Zero goals and resiliency .....................................37

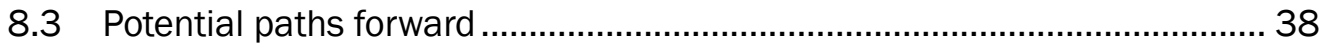

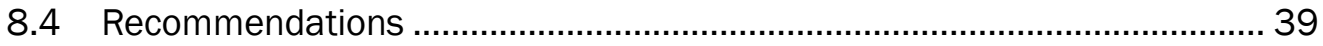

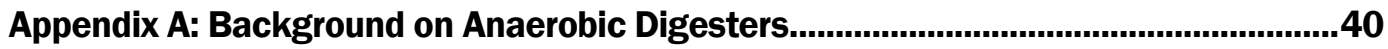

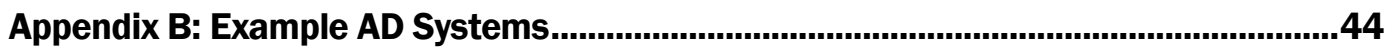

Appendix C: Summary of Biological Process of Anaerobic Digestion ...........................51

Appendix D: Co-Digestion Economic Analysis Tool (Co-EAT) Scenario

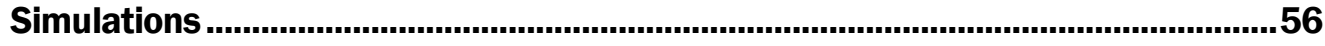

Appendix E: Calculations and Assumptions for Heating Demand in Co-EAT

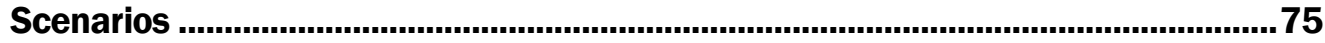

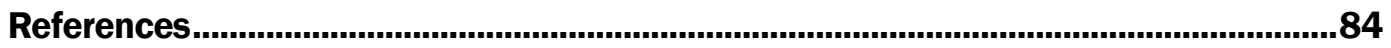

Report Documentation Page 


\section{Figures and Tables}

\section{Figures}

Figure 1. Net Zero energy, water, and waste hierarchies (U.S. Army 2011)....................... 1

Figure 2. Fort Huachuca's annual waste generation by type (ERDC-CERL). ....................... 5

Figure 3. Waste diversion potential at Fort Huachuca (ERDC-CERL)................................. 6

Figure 4. Unused trickling filter at Fort Huachuca's wastewater treatment plant (ERDC-CERL).

Figure 5. Aerial image of WWTP2 at Fort Huachuca (www.maps.google.with ERDC-CERL annotation)

Figure 6. Average daily inflow to WWTP2 at Fort Huachuca, AZ (data from Fort Huachuca DPW, graph by ERDC-CERL

Figure 7. Energy intensity of similar-sized treatment plants (data from phone conversation 12 July 2016 with Srirupa Ganguly, Process Development Engineer for Illinois Sustainable Technology Center; graph by ERDC-CERL).

Figure 8. Electric consumption at Fort Huachuca, FY2014-2015 (data from Fort Huachuca DPW, graphed by ERDC-CERL)

Figure 9. Schematic of Co-Digestion Economic Analysis Tool (CoEAT), identifying key components of the model (U.S. EPA Office of Research and Development [ORD]).

Figure 10. Total heating demand vs. percent solids of mixed feedstock (U.S. EPA ORD).

Figure 11. Net annual value vs. percent solids (U.S. EPA, ORD).

Figure 12. Existing process flow diagram of WWTP of Fort Huachuca, AZ (All Star 2012, modified by ERDC-CERL).

Figure 13. Dual membrane digester, showing layering of membrane covers (Natural Systems Utilities 2015).

Figure 14. Potential two-phase WWTP process flow diagram at Fort Huachuca (All Star 2012, modified by ERDC-CERL).

\section{Tables}

Table 1. WWTP2 electric consumption at Fort Huachuca, FY2014-2015 (data from Fort Huachuca DPW).

Table 2. List of Facilities on Fort Huachuca that can supply cooking oil and grease to the WWTP and the amounts produced (ERDC-CERL).

Table 3. AD feedstock scenarios (ERDC-CERL).................................................................. 17

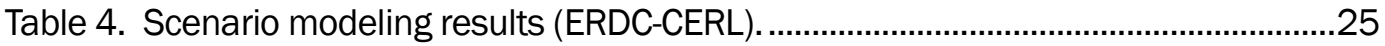

Table 5. Costs estimates for AD system upgrades (ERDC-CERL).......................................35

Table 6. Summary of findings for two potential paths forward.........................................38 


\section{Preface}

This study was conducted for the Assistant Secretary of the Army for Installations, Energy and Environment under Military Interdepartmental Purchase Request (MIPR) No. 10767390, accepted 18 September 2015 as P2 Project No. 455592, “EPA Net Zero Project Support.” The sponsor's technical monitor was Dr. Marc Kodack.

The work was performed by the Environmental Processes Branch (CNE) of the Installations Division (CN), U.S. Army Engineer Research and Development Center, Construction Engineering Research Laboratory (ERDC-CERL). At the time of publication, Mr. Garth Anderson was Chief, CEERD-CNE; Ms. Michelle Hanson was Chief, CEERD-CN; and Mr. Kurt J. Kinnevan, CEERD-CZT was the Technical Director for Adaptive and Resilient Installations The Deputy Director of ERDC-CERL was Dr. Kirankumar Topudurti, and the Director was Dr. Ilker Adiguzel.

The Commander of ERDC was COL Bryan S. Green, and the Director was Dr. David W. Pittman. 


\section{Unit Conversion Factors}

\begin{tabular}{|c|c|c|}
\hline Multiply & By & To Obtain \\
\hline acres & $4,046.873$ & square meters \\
\hline British thermal units (International Table) & $1,055.056$ & joules \\
\hline cubic feet & 0.02831685 & cubic meters \\
\hline degrees Fahrenheit & $(\mathrm{F}-32) / 1.8$ & degrees Celsius \\
\hline gallons (U.S. liquid) & $3.785412 \mathrm{E}-03$ & cubic meters \\
\hline square feet & 0.09290304 & square meters \\
\hline square miles & $2.589998 \mathrm{E}+06$ & square meters \\
\hline tons ( 2,000 pounds, mass) & 907.1847 & kilograms \\
\hline
\end{tabular}




\section{Abbreviations}

\begin{tabular}{|c|c|}
\hline Abbreviation & Spell-Out \\
\hline AAFES & Army and Air Force Exchange Service \\
\hline$A D$ & anaerobic digestion \\
\hline ADWF & average dry-weather flow \\
\hline APP & Aquifer Protection Permit \\
\hline ASA (IE\&E) & $\begin{array}{l}\text { Assistant Secretary to the Army (Installations, Energy and } \\
\text { Environment }\end{array}$ \\
\hline ASIP & Army Stationing and Installation Plan \\
\hline BOD & biological oxygen demand \\
\hline $\mathrm{CHP}$ & combined heat and power \\
\hline CMSA & Central Marin Sanitation Agency \\
\hline COD & chemical oxygen demand \\
\hline CoEAT & Co-Digestion Economic Analysis Tool \\
\hline DFAC & dining facility \\
\hline DOE & Department of Energy \\
\hline DPW & Directorate of Public Works \\
\hline EBMUD & East Bay Municipal Utility District \\
\hline EO & Executive Order \\
\hline EPA & Environmental Protection Agency \\
\hline ERDC-CERL & $\begin{array}{l}\text { Engineer Research Development Center-Construction Engineering } \\
\text { Research Laboratory }\end{array}$ \\
\hline FOG & fats, oils, and grease \\
\hline FY & fiscal year \\
\hline GPD & gallons per day \\
\hline GUI & graphical user interface \\
\hline HCTP & Hill Canyon Wastewater Treatment Plant \\
\hline HRT & hydraulic retention time \\
\hline LRC & Logistics Readiness Center \\
\hline MG & million gallons \\
\hline MGD & million gallons per day \\
\hline MIPR & Military Interdepartmental Purchase Request \\
\hline
\end{tabular}




\begin{tabular}{|l|l|}
\hline Abbreviation & Spell-Out \\
\hline MMH & Michael Military Housing \\
\hline MVC & Mountain Vista Communities \\
\hline MWR & Morale, Welfare, \& Recreation \\
\hline OCC & old corrugated cardboard \\
\hline ORD & Office of Research and Development (EPA) \\
\hline RCI & Residential Communities Initiative \\
\hline TIC & total inorganic carbon \\
\hline TS & total solids \\
\hline USDA & U.S. Department of Agriculture \\
\hline VFA & volatile fatty acids \\
\hline VS & volatile solids \\
\hline WAS & waste-activated sludge \\
\hline WWII & World War II \\
\hline WWTP & wastewater treatment plant \\
\hline
\end{tabular}


(This page intentionally blank.) 


\section{Introduction}

\subsection{Background}

\subsubsection{Army Net Zero Initiative}

Net Zero is a strategy that strives to bring the overall consumption of resources on installations down to zero. The Army Net Zero Initiative began in 2011 with 17 pilot installations (U.S. Army 2011). The primary goal of the initiative is to integrate sustainability practices at the installation level to preserve the installation's flexibility to operate in constrained circumstances, either economic or environmental. Army Net Zero is a holistic approach to preserve natural resources by focusing on energy, water, and waste at Army installations. Each individual focus area's hierarchy is meant to work together and has the same five interrelated steps: reduction, repurpose, recycling and composting, energy recovery, and disposal. Each step is a link to achieving net zero (Figure 1).

Figure 1. Net Zero energy, water, and waste hierarchies (U.S. Army 2011).

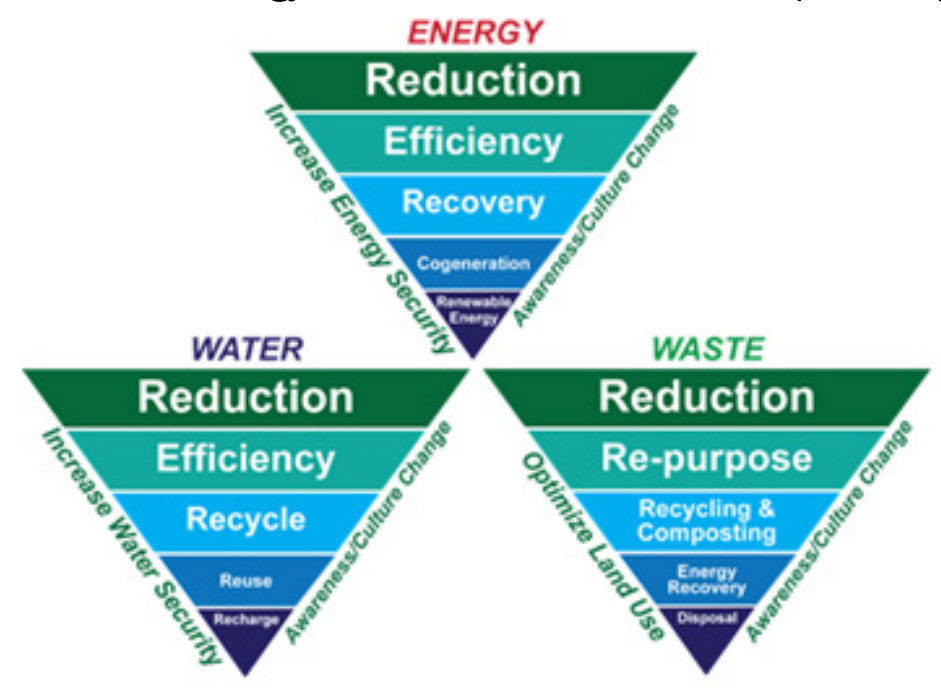

Executive Order (EO) 13693, signed by President Obama in March 2015, requires changes in federal agency processes and procedures in order to reduce greenhouse gas emissions. This EO replaces, but still promotes the goals set forth for waste reduction in EO 13514 (50\% nonhazardous solid waste and 50\% construction debris), and provides additional goals for compostable material as part of the nonhazardous waste that must be reduced. 
In January 2014, Army Directive 2014-02, "Net Zero Installations Policy" set policy and assigned responsibility to strive toward Net Zero at all Army installations wherever fiscally responsible (U.S. Army 2014). The policy directive applies to all permanent Active Army, Army National Guard, and U.S. Army Reserve installations and asks Army Commands to implement Net Zero to the maximum extent. For Net Zero Energy, the policy directs installations to produce as much energy on site as is being used. For Net Zero Waste, the policy directs installations to reduce, reuse, recycle, and compost, as well as to recover solid waste streams and convert the waste to resources to the greatest possible extent, resulting in zero landfill disposal. For Net Zero Water, the policy directs the installation to limit consumption of freshwater resources and return water to the same watershed in order not to deplete the quantity and quality of groundwater and surfacewater resources. The original Net Zero pilot installations will continue to strive to meet their Net Zero goals by fiscal year (FY) 2020. The memo elaborates by stating, "Commands will continually evaluate and implement efficiencies, reductions, and reuse of energy, water and solid waste to the maximum extent possible within available funding levels and as new technologies and approaches are proven cost-effective."

\subsubsection{Energy, water, and waste interconnections}

Energy, water, and waste interactions have a direct effect on the availability of these resources. In order to achieve more sustainable operations, the nexus between these three resources must be considered. A prime example of their interaction is the operation of a wastewater treatment plant (WWTP), where energy, water, and waste interconnect and affect one another. In terms of water, the organic concentration of the wastewater is dependent on the quality and concentration of the various elements coming into the plant. This concentration of elements is typically associated with domestic water use. The influent water concentration directly influences the efficiency and potential reuse of the effluent. For energy, wastewater treatment is an energy-intensive process. Energy use is especially intensive during aeration, which is an important step in properly treating wastewater. For waste, disposal of biosolids is a significant cost that the treatment facility must support. The biosolids also take up a great deal of physical space and volume prior to disposal.

While energy, water, and waste may be dependent on one another in terms of use, those interconnections can be used to benefit the WWTP system. 
Energy generation for the WWTP is possible via biogas from anaerobic digestion (AD) of biosolids fed into the plant. Instead of paying for disposal of sludge and food these, waste materials can create energy in the form of electric power for the plant. The extra heat and power generated from this process can be exported to the grid and biosolids not fed to the plant can be composted for agricultural purposes and used as a soil amendment.

\subsection{Objectives}

The project's objectives were to evaluate the feasibility of food waste co-digestion to (1) reduce the amount of organic material going to landfill, (2) reduce greenhouse gas emissions, and (3) produce renewable energy.

\subsection{Methodology}

This feasibility study is the product of a collaborative effort between the U.S. Army Engineer Research and Development Center-Construction Engineering Research Laboratory (ERDC-CERL) and the U.S. Environmental Protection Agency (EPA), Office of Research and Development. The project was conducted at the U.S. Army installation, Fort Huachuca, Arizona. As part of its greater vision of strategic sustainability, Fort Huachuca seeks to meet Army Net Zero objectives.

This report identifies baseline data and information such as food waste volume, management options, disposal practices, and associated costs unique to Fort Huachuca. Further, this report develops suitable indicators and performance measures, and determines the economic feasibility and capital investments required. These details are integrated into a final recommendation for consideration by Fort Huachuca stakeholders to evaluate a feasible option for an effective long-term sustainability solution that will keep resource costs low and provide environmental and economic benefits to the installation. 


\section{Fort Huachuca}

\subsection{Overview of the installation}

U.S. Army Garrison Fort Huachuca is located in Cochise County in southeast Arizona and covers 80,000 acres of land. It is located 60 miles south of Tucson and 15 miles north of the Mexican border. The primary mission of Fort Huachuca is to direct and coordinate installation garrison operations and training support activities while providing force protection, mobilization and demobilization, reserve component training support, and operational planning and emergency operation functions, to provide a focused training environment for all Fort Huachuca tenants, and partner organizations. The majority of installation activities relate to intelligence, electronic warfare, and communication systems. Training of over 14,000 students is completed each year on the installation in the areas of research, development, testing and operation of intelligence, electronic warfare, and communications systems.

Population data derived from estimates projected in 2013 from the Army Stationing and Installation Plan (ASIP) FY2011-FY2019 indicates that the installation's population is expected to remain steady through 2019, with approximately 6,200 military personnel; 9,000 civilians; and 120 Reserve soldiers. ${ }^{1}$

\subsection{Waste characterization study}

Understanding the composition of the current waste stream of the installation is crucial in providing leadership and key personnel with tools to better assess the future of waste reduction and diversion program efforts.

In summer 2015, a team of representatives from ERDC-CERL performed a waste characterization at Fort Huachuca. By using a modified version of the waste characterization method from ASTM D5231, Standard Test Method for Determination of the Composition of Unprocessed Municipal Solid Waste, the team conducted a thorough analysis of all nonhazardous waste components generated at the garrison level.

\footnotetext{
${ }^{1}$ Retrieved from https://asip.hqda.pentagon.mil/default_asip/default.htm, 16 February 2017.
} 
The characterization revealed that buildings where food is produced, such as dining facilities (DFAC) and restaurants, have the largest amount of waste. Combined, there are almost 2,00o tons of food waste produced from these facilities annually. The analysis also indicated that there are 1,200 tons of white paper (annually) in the waste stream, none of which is recycled. Old corrugated cardboard (OCC) is another high-waste component with 500 tons in the waste stream per year, none of which is currently recycled.

Figure 2 presents a visual representation of the waste stream's distribution. It shows that food and white paper represent the largest percentage of the waste stream at just over $50 \%$ combined.

Figure 2. Fort Huachuca's annual waste generation by type (ERDC-CERL).

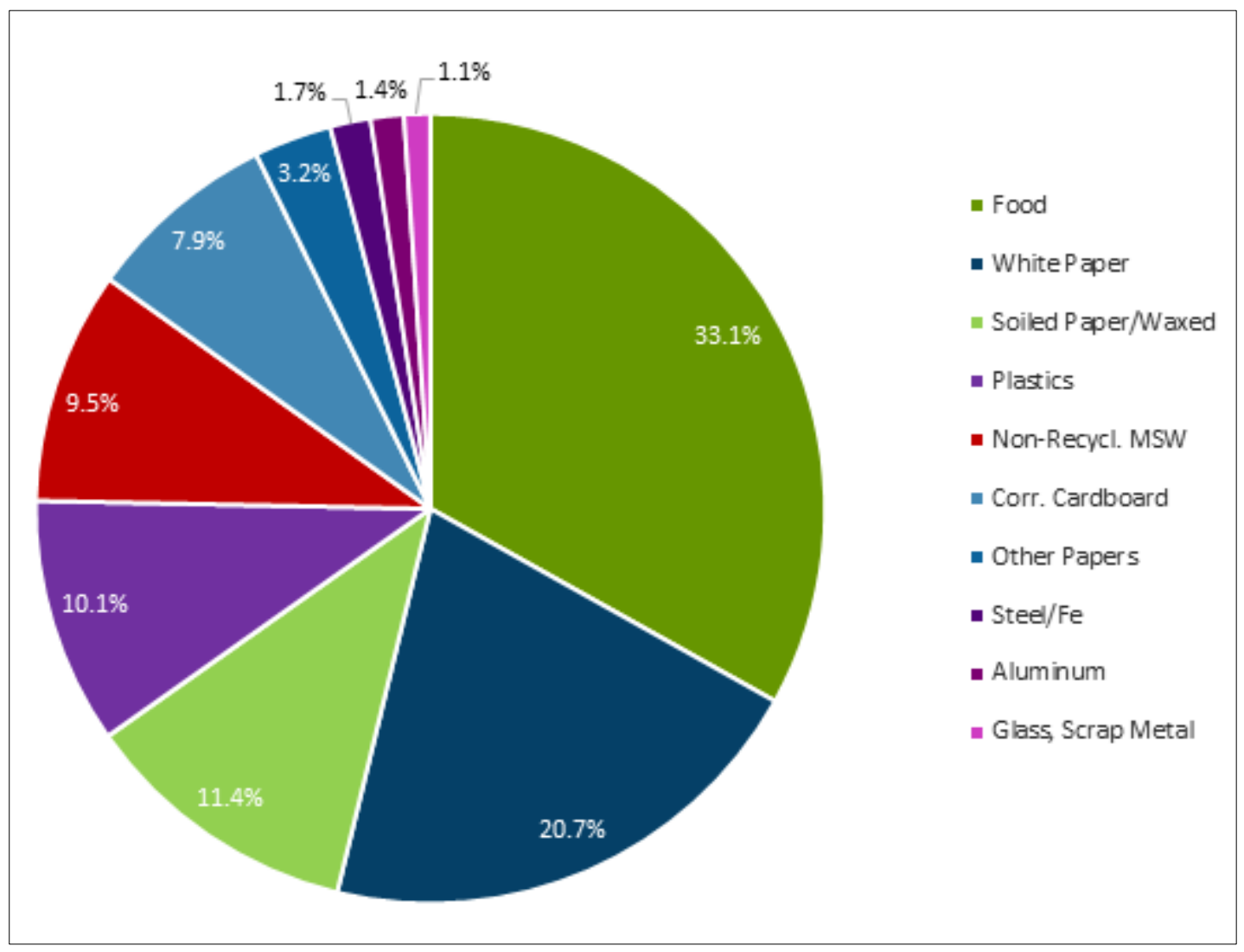

Figure 2's categories suggest that nearly $45 \%$ of all waste disposed on Fort Huachuca is organic waste, such as food and soiled paper products. The categories in Figure 2 also show that another 44\% of remaining categories of waste disposed by Fort Huachuca is recyclable. Thus, only $11 \%$ is nonrecyclable, which means that $89 \%$ of all waste can be diverted from a land- 
fill. Figure 3 shows that of this $89 \%, 45 \%$ is compostable and $44 \%$ is recyclable. Thus, the possibilities for diversion of Fort Huachuca's waste stream to an $\mathrm{AD}$ system are very high.

Figure 3. Waste diversion potential at Fort Huachuca (ERDC-CERL).

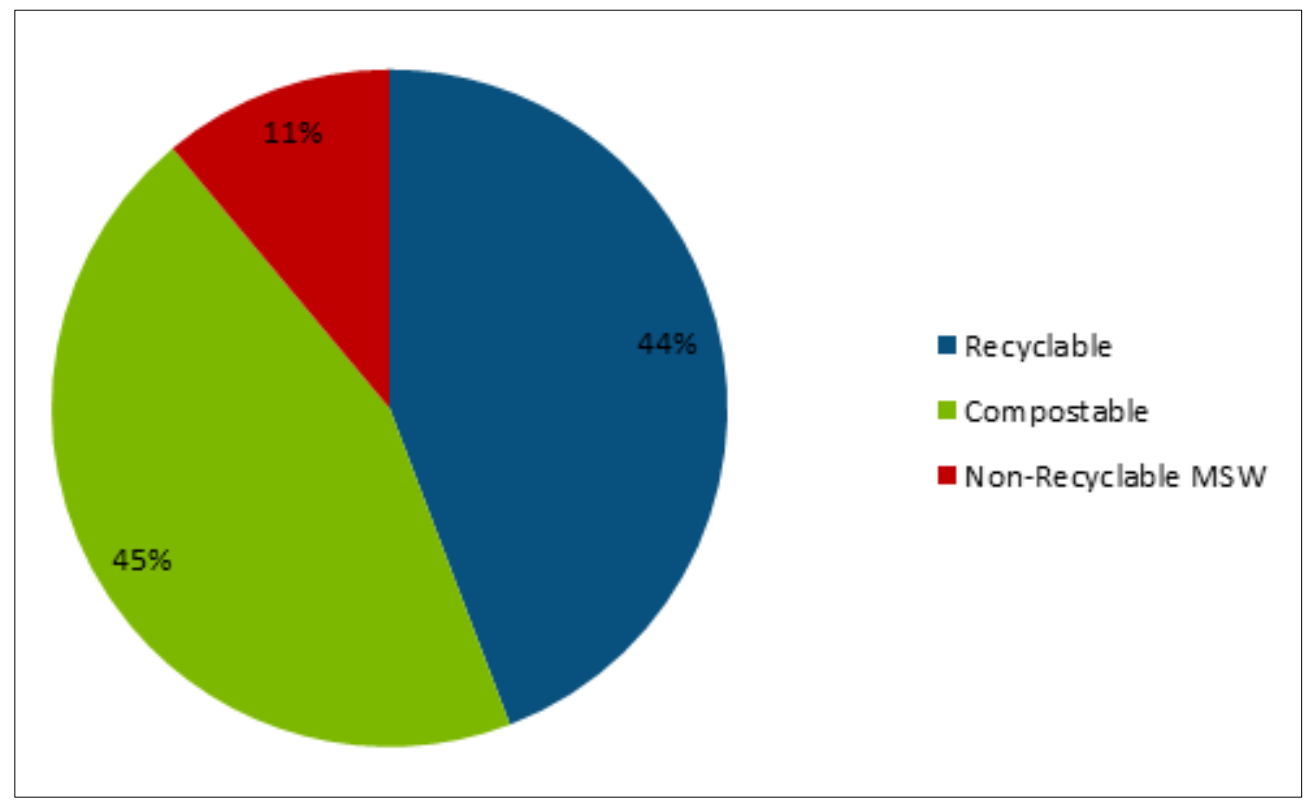




\section{Fort Huachuca's Wastewater Treatment Plant}

\subsection{History and infrastructure}

Fort Huachuca expanded considerably during the nationwide World War II (WWII) buildup. Two WWTPs were constructed to handle the influx of personnel. In subsequent years, one of the treatment plants was removed. The remaining plant is referred to as WWTP2. Throughout much of the plant's history, a trickling filter was the main approach for organic treatment, and sludge generation (Figure 4). Use of the trickling filter was discontinued in 2002 in favor of an oxidation ditch for improved nutrient removal. The ditch achieves around 50\% solids removal.

The design and permitted capacity of WWTP2 is 2 million gallons per day (GPD). However, the average daily influent volume is 570,000 gallons. After the wastewater is discharged from the plant, some of it is used to irrigate the golf course and some of it is used to recharge the aquifer. Annually, $60 \%$ of the wastewater is used to irrigate the golf course and $40 \%$ is used to recharge the aquifer. The incoming wastewater has an organic loading that is three times stronger than a typical municipality, because the organic waste is not overly diluted with fresh water, which is due to the installation's aggressive water conservation strategies.

The AD system was originally built to handle the volume of sludge coming off the trickling filters which meant it was relatively concentrated. Now the sludge comes from the oxidation ditch at much higher volumes and lower solids concentrations: 40,000 GPD at $1 \%$ solids. Currently, the plant is government-owned and contractor-operated. Figure 5 provides a current aerial view of the plant, with major functions labeled. Figure 6 shows the average daily inflow for each month in 2015. The annual average is 570,000 GPD. 
Figure 4. Unused trickling filter at Fort Huachuca's wastewater treatment plant (ERDC-CERL).

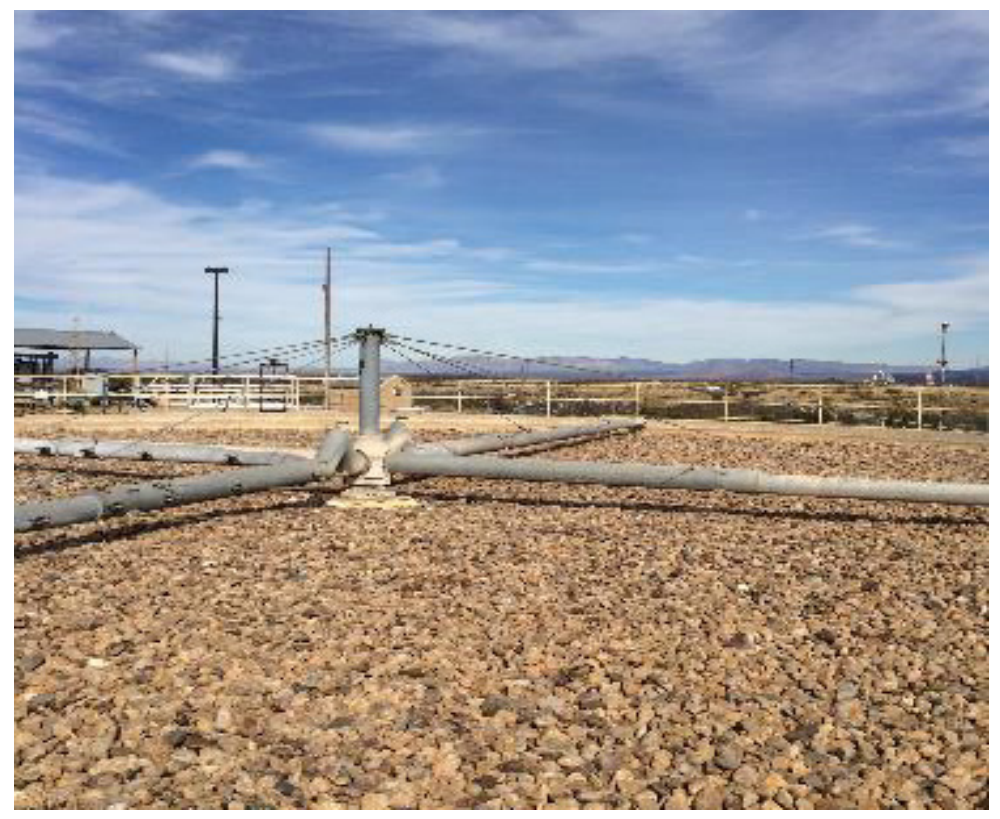

Figure 5. Aerial image of WWTP2 at Fort Huachuca (www.maps.google.with ERDCCERL annotation).

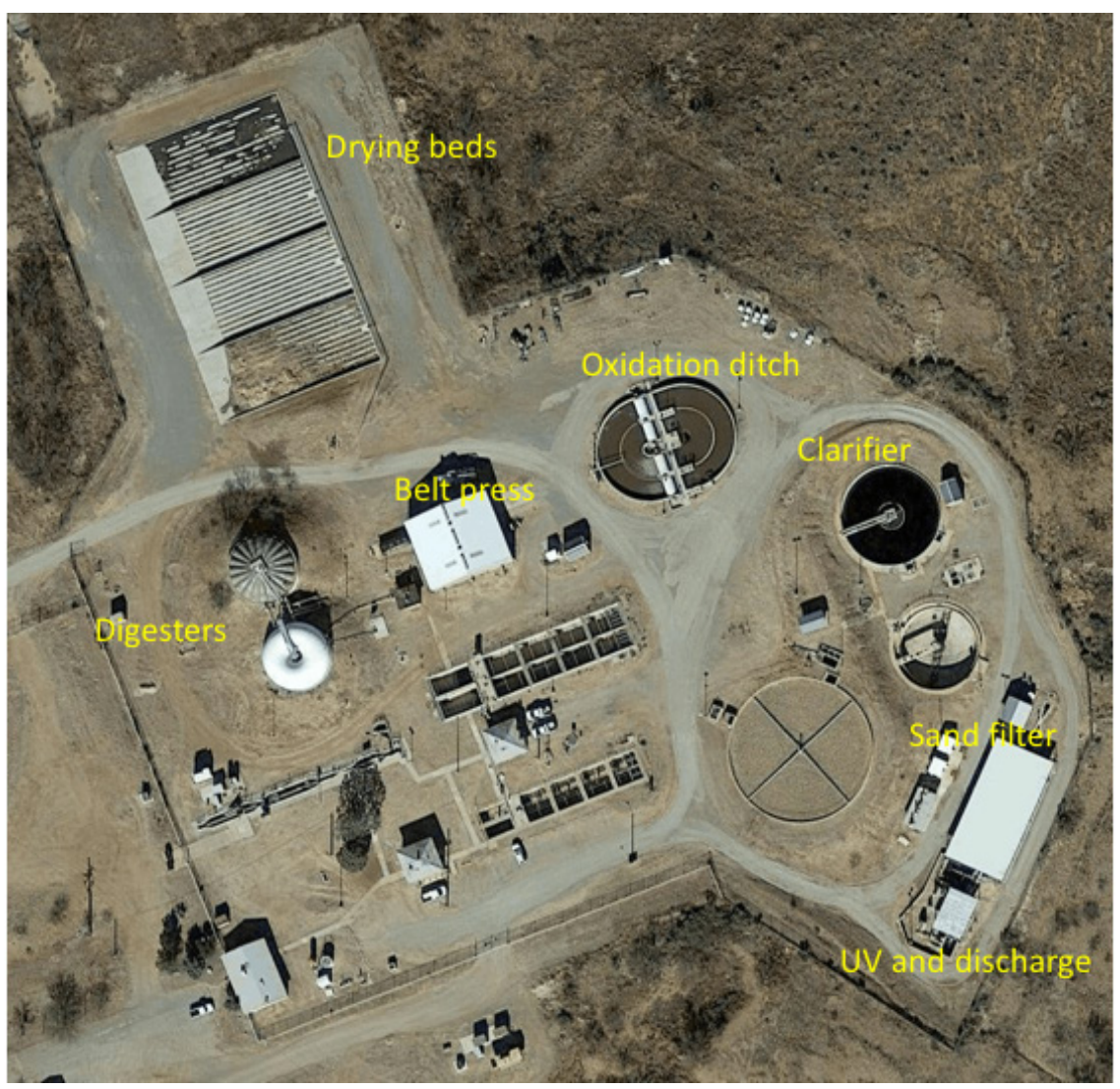


Figure 6. Average daily inflow to WWTP2 at Fort Huachuca, AZ (data from Fort Huachuca Directorate of Public works [DPW], graph by ERDC-CERL).

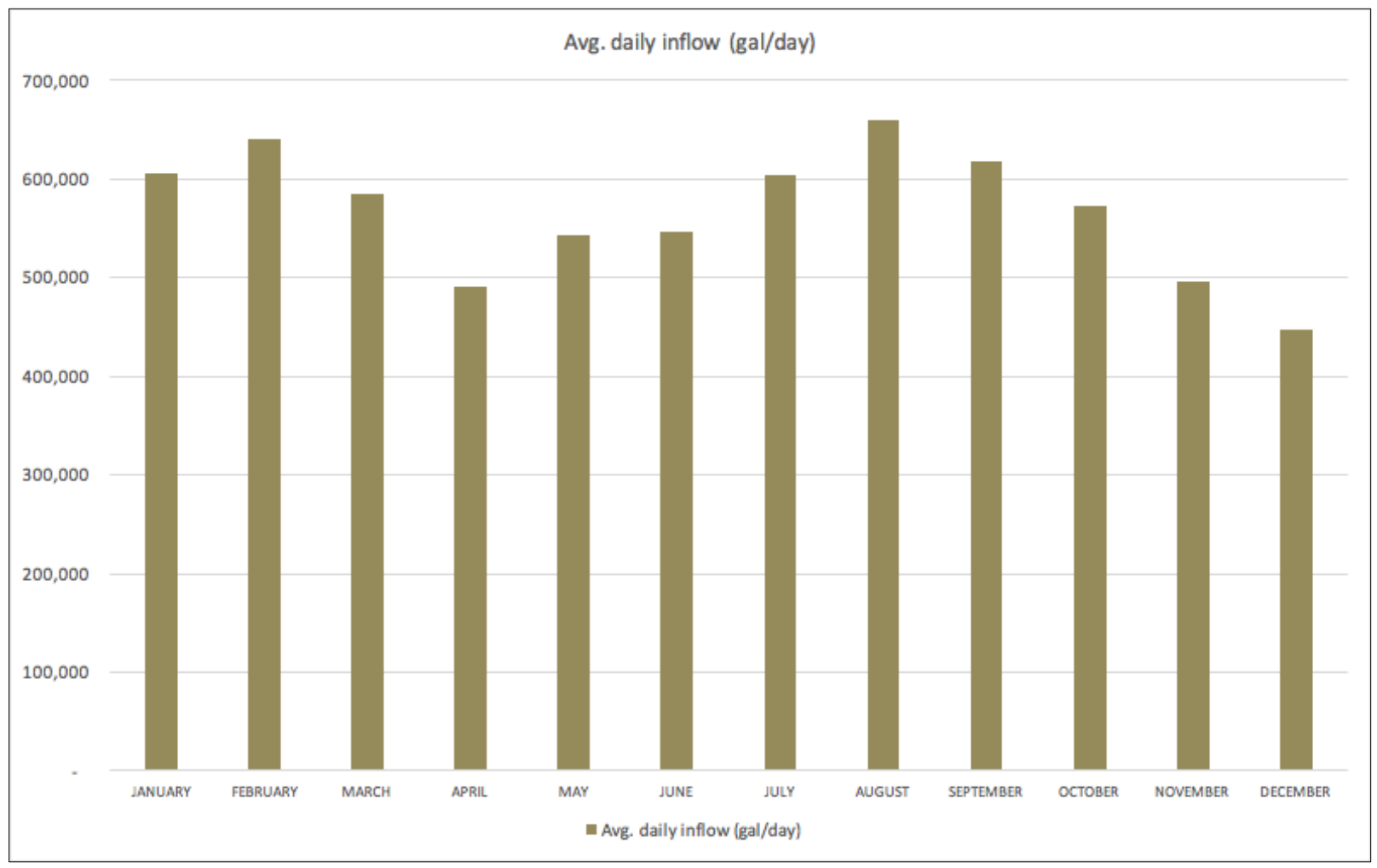

\subsection{Energy consumption}

Table 1 shows energy consumption and intensity at WWTP2. A common unit of energy intensity for wastewater plants is energy expended per volume influent, usually expressed as kilowatt-hours (kWhr) per million gallons per day (MGD) inflow.

Figure 7 shows the energy intensity curve for treatment plants of a similar size. ${ }^{2}$ Note that Fort Huachuca's WWTP2 average energy intensity falls below the curve, indicating that operations are relatively energy efficient. Figure 8 tracks two years of daily power consumption at WWTP2.

\footnotetext{
2 Personal communications on 12 July 2016 between co-author Steve Cosper and Srirupa Ganguly, Process Development Engineer for Illinois Sustainable Technology Center.
} 
Table 1. WWTP2 electric consumption at Fort Huachuca, FY2014-2015 (data from Fort Huachuca DPW).

\begin{tabular}{|c|c|c|c|}
\hline & $\begin{array}{l}\text { Daily Consumption } \\
\text { (kWhr) }\end{array}$ & $\begin{array}{l}\text { Energy Use Intensity } \\
\text { (kWhr/MGD) }\end{array}$ & $\begin{array}{l}\text { Average Daily } \\
\text { Load (kW) }\end{array}$ \\
\hline Average & 1,019 & 1,800 & 42.5 \\
\hline Maximum & 2,420 & $4,500 *$ & 101.0 \\
\hline Minimum & 460 & $1,340 *$ & 19.2 \\
\hline
\end{tabular}

* Note that these two figures represent the maximum and minimum daily energy use divided by the inflow on that day.

Figure 7. Energy intensity of similar-sized treatment plants (data from phone conversation 12 July 2016 with Srirupa Ganguly, Process Development Engineer for Illinois Sustainable Technology Center; graph by ERDC-CERL).

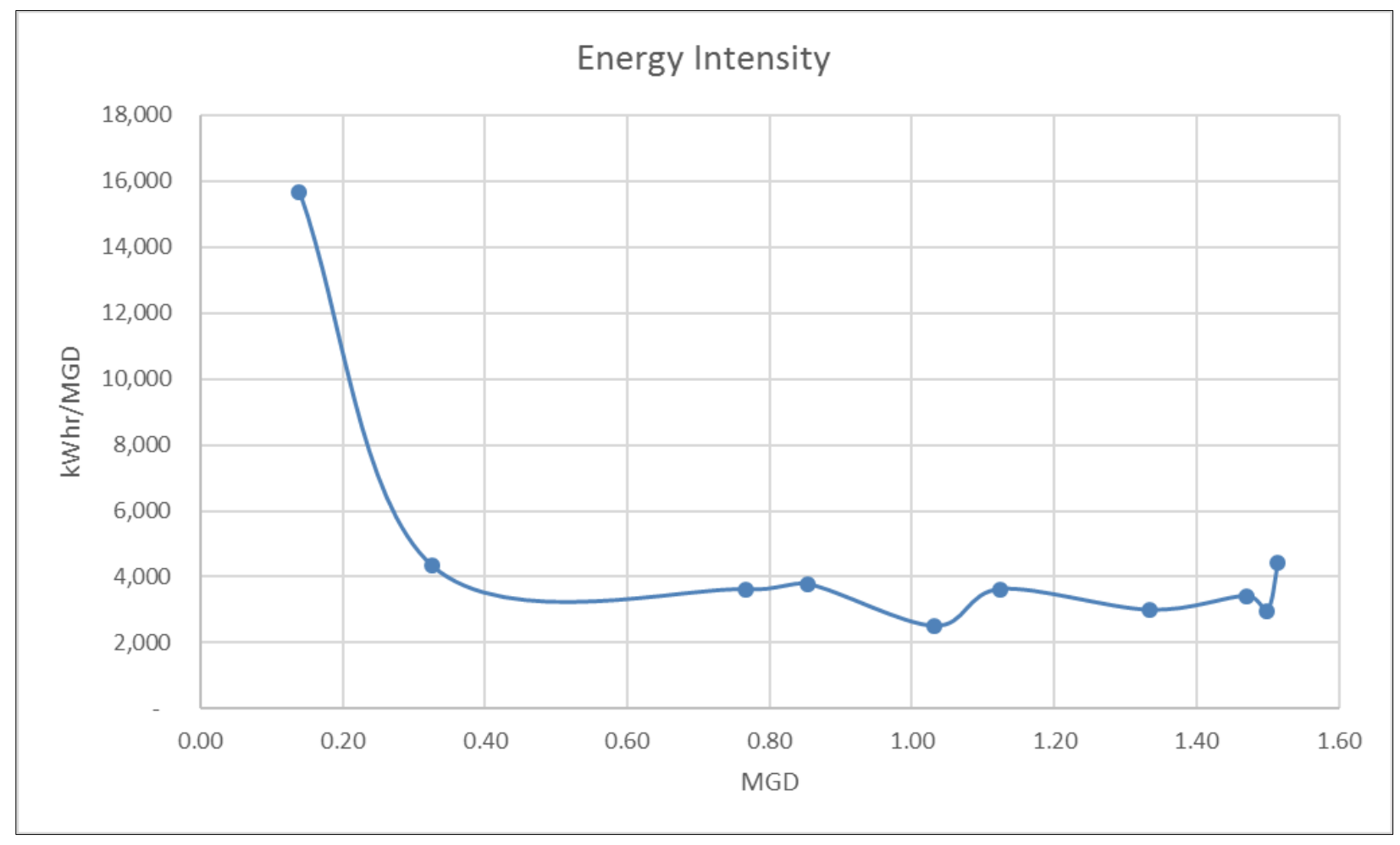


Figure 8. Electric consumption at Fort Huachuca, FY2014-2015 (data from Fort Huachuca DPW, graphed by ERDC-CERL).

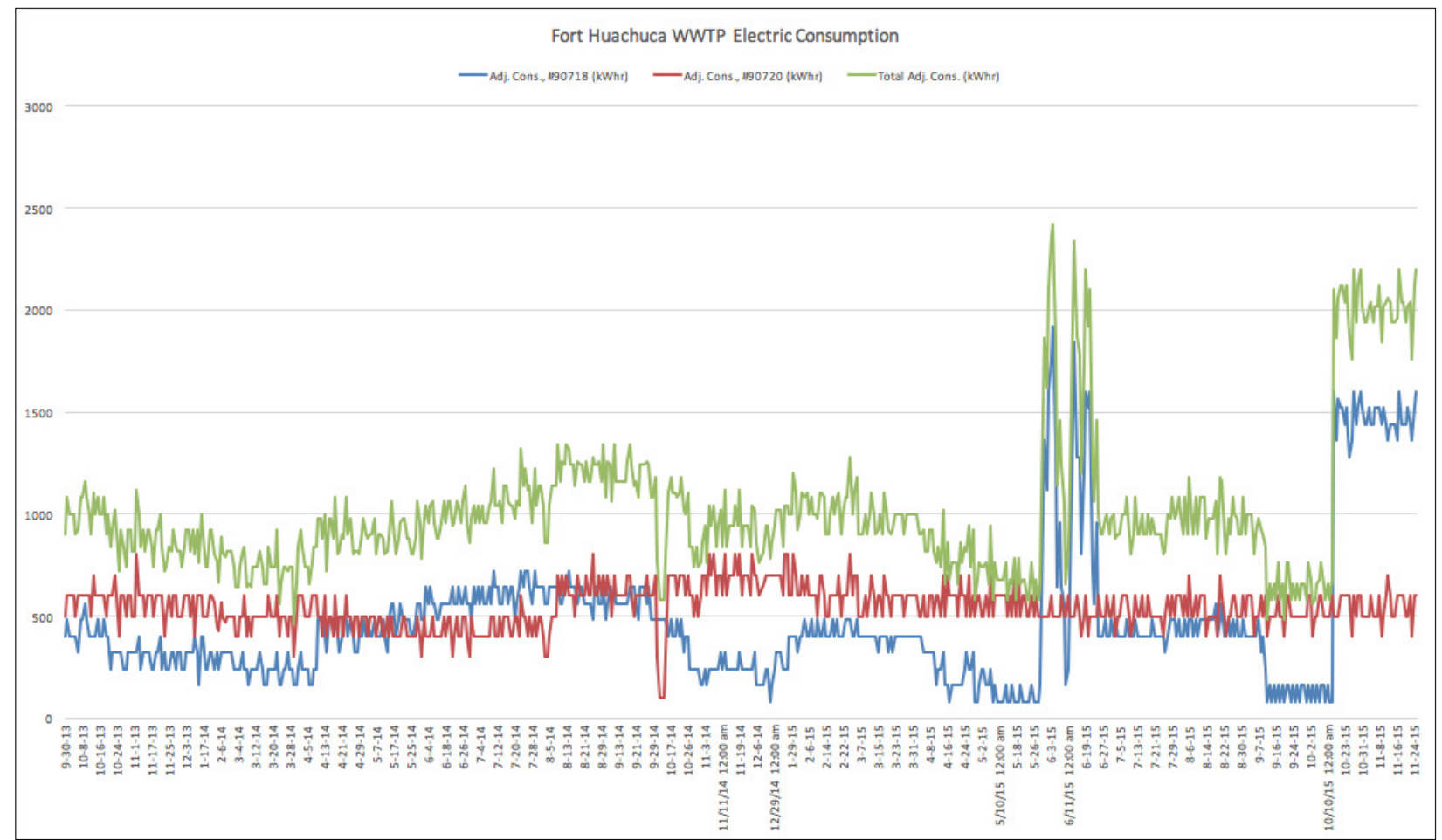

\subsection{Technical issues}

Fort Huachuca has implemented water conservation strategies that have reduced its water use by $65 \%$. However, the organic loading to the treatment plant from the current population of people has not changed. Before water conservation efforts started at Fort Huachuca, the ammonia concentration in the wastewater was about $15 \mathrm{mg} / \mathrm{L}$. Now, after water conservation efforts have been implemented, the ammonia concentration varies from $60-80 \mathrm{mg} / \mathrm{L}$. Water conservation means there is less water in the influent, which results in a more concentrated influent. Water conservation is attributed in part to waterless urinals and low-flow toilets. While the incoming biological oxygen demand (BOD) loading is close to normal, the chemical oxygen demand (COD) is over $1,500 \mathrm{mg} / \mathrm{L}$. In short, the Fort Huachuca WWTP has a very high nutrient load with a very low-flow influent, and this combination often results in high nitrogen levels.

High nitrogen levels present challenges for compliance with state water quality regulations. Fort Huachuca's WWTP is permitted in terms of total nitrogen for an action level of $8.0 \mathrm{ml} / \mathrm{L}$, but the discharge level is usually $10 \mathrm{mg} / \mathrm{L}$ of total nitrogen. While the WWTP management has made strides in decreasing nitrogen loads, the installation's water conservation efforts 
continue to improve, and that improvement results in ongoing compliance issues.

\subsection{Regulatory issues}

Currently, the Fort Huachuca WWTP and Recharge Facility operates under an Aquifer Protection Permit (APP) and a Reuse Permit that allows the WWTP to use the effluent for irrigation of the golf course. The APP is sitespecific, and it includes a description of what equipment the plant has.

In order to process large quantities of food through the WWTP, Fort Huachuca would need to apply for an amendment to the current APP. As part of that process, the change in influent characteristics and the resulting effect on the treatment process needs to be analyzed and evaluated. This analysis should demonstrate that the added food will not adversely affect the treatment process or cause it to exceed any of the permit conditions, including flow rate and effluent quality. The amended APP will not expire, as it is issued for the life of the facility. 


\section{Feasibility of Co-digestion}

\subsection{Potential feedstocks}

The key to sustaining a viable co-digestion operation is obtaining a secure and consistent supply of feedstocks. At Fort Huachuca, there are four feedstocks that can be made available for the anaerobic digester in addition to biosolids: (1) sludge, (2) food, (3) grease, and (4) cooking oil. All these feedstocks come from different sources. To give examples: (a) sludge is made up of residue from primary clarifiers and waste-activated sludge from the oxidation ditch, (b) food waste is generated primarily from the on-post DFACs, and (c) grease and cooking oil are produced at a number of food-service facilities on the installation, including the DFACs.

The yield of biogas from a particular feedstock will vary according to a number of criteria that include type of feedstock and potential energy embodied within a given feedstock. The most easily obtained feedstock for a potential $\mathrm{AD}$ operation at Fort Huachuca is the sludge, because it is produced at the same location where the $\mathrm{AD}$ is located. The current WWTP produces sludge from their activated sludge tanks at $0.5 \%$ solids. This sludge is dried to $1 \%$ solids yielding 40,000 gal of sludge per day. This percentage means that the WWTP generates 400 gallons of dry sludge per day. This sludge is $5 \%-6 \%$ lower in solids than is required to run the $\mathrm{AD}$ efficiently. While the current WWTP processes are better at meeting modern discharge limits, it is not feasible to put this sludge in an anaerobic digester without first dewatering it.

As discussed above in section 2.2, the waste characterization study performed at Fort Huachuca provided detailed analyses of the waste stream, primary generators of each waste component, and a measured sample from the representative buildings chosen for the study. The study revealed that the DFACs and Commissary at Fort Huachuca, respectively produced food waste of 1.9 tons (1,000 gal) per day and 0.23 tons (125 gal) per day.

Grease from the grease traps and used cooking oil are generated from the food-service facilities in on-post mini-malls, commissaries, and DFACs. See Table 2 for a list of facilities on Fort Huachuca that produce cooking oil (10 facilities) and grease (19 facilities). This combination results in an approximate total of 455 GPD of grease and an approximate total of 723 GPD of cooking oil generated on post. With the addition of the food waste, 
cooking oil, and grease feedstocks, the percent solids will be adequate to run the $\mathrm{AD}$ system efficiently.

Table 2. List of Facilities on Fort Huachuca that can supply cooking oil and grease to the WWTP and the amounts produced (ERDC-CERL).

\begin{tabular}{|c|c|c|c|}
\hline Affiliation & Location & $\begin{array}{l}\text { Cooking Oil } \\
\text { (gal/day) }\end{array}$ & \begin{tabular}{|l} 
Grease \\
(gal/day)
\end{tabular} \\
\hline \multirow{5}{*}{$\begin{array}{l}\text { Army and Air } \\
\text { Force Exchange } \\
\text { Service (AAFES) }\end{array}$} & Burger King & 146.00 & \\
\hline & Popeyes & 10.00 & \\
\hline & Charleys & 1.87 & \\
\hline & Taco Bell & 0.93 & \\
\hline & Greely Hall & 2.67 & \\
\hline \multirow{4}{*}{$\begin{array}{l}\text { Morale, Welfare, } \\
\text { and Recreation } \\
\text { (MWR) }\end{array}$} & 19th Hole Lounge & 58.33 & \\
\hline & TMAC & 58.33 & \\
\hline & Jeannie's Diner & 58.33 & \\
\hline & Yardley Pizza & 58.33 & \\
\hline \multirow{2}{*}{$\begin{array}{l}\text { Logistics } \\
\text { Readiness } \\
\text { Center (LRC) }\end{array}$} & Weinstein & \multirow{2}{*}{60.00} & \\
\hline & Thunderbird & & \\
\hline \multirow[t]{6}{*}{ Garrison } & $\begin{array}{l}\text { Black Tower Dining } \\
\text { Facility }\end{array}$ & & $\sim 11.00$ \\
\hline & $\begin{array}{l}\text { Golf Course (19th } \\
\text { Hole) }\end{array}$ & & 16.00 \\
\hline & Child Care Center & & 1.00 \\
\hline & $\begin{array}{l}\text { Child Care Center } \\
\text { Annex }\end{array}$ & & $\sim 44.00$ \\
\hline & Burger King & & 20.00 \\
\hline & Bowling Alley & & 33.00 \\
\hline
\end{tabular}




\begin{tabular}{|c|c|c|c|}
\hline Affiliation & Location & $\begin{array}{l}\text { Cooking Oil } \\
\text { (gal/day) }\end{array}$ & $\begin{array}{l}\text { Grease } \\
\text { (gal/day) }\end{array}$ \\
\hline \multirow[t]{13}{*}{ Garrison (cont'd) } & $\begin{array}{l}\text { School Age } \\
\text { Services }\end{array}$ & & 16.00 \\
\hline & $\begin{array}{l}\text { Thunderbird Dining } \\
\text { Facility }\end{array}$ & & 33.00 \\
\hline & $\begin{array}{l}\text { Family Fitness } \\
\text { Center }\end{array}$ & & $\sim 0.50$ \\
\hline & Commissary & & 8.00 \\
\hline & $\begin{array}{l}\text { Greely Hall } \\
\text { Cafeteria }\end{array}$ & & 33.00 \\
\hline & $\begin{array}{l}\text { Thunder Mountain } \\
\text { Activity Center }\end{array}$ & & 66.00 \\
\hline & $\begin{array}{l}\text { Virginia Dining } \\
\text { Facility }\end{array}$ & & $\sim 23.00$ \\
\hline & $\begin{array}{l}\text { Yardley Dining } \\
\text { Facility }\end{array}$ & & $\sim 22.00$ \\
\hline & AAFES Mini-Mall & & 16.00 \\
\hline & $\begin{array}{l}\text { Weinstein Dining } \\
\text { Facility }\end{array}$ & & 315.00 \\
\hline & Fire Station \#3 & & 2.00 \\
\hline & $\begin{array}{l}\text { Labor Emergency } \\
\text { Services }\end{array}$ & & $\sim 0.50$ \\
\hline & $\begin{array}{l}\text { Emergency } \\
\text { Services }\end{array}$ & & $\sim 66.00$ \\
\hline
\end{tabular}




\subsection{Future feedstocks to explore}

On-post family housing at Fort Huachuca is run by a private entity through the U.S. Army Residential Communities Initiative (RCI). Under this program, single-family and duplex homes in Fort Huachuca are operated by Michaels Military Housing (MMH) and serviced through a contract with Mountain Vista Communities (MVC). There currently are approximately 1,167 privatized family housing units on post.

Within each one of these housing units comes potential for yet another feedstock opportunity. Fats, oils and grease (FOG) is the residue from cooking meat and other types of high-fat foods found in residential kitchens. While it can cause damage to pipes if washed down the drain, it is useful as an additive in $\mathrm{AD}$. There are diversion programs for residential FOG throughout the country-in Florida, Alabama, Texas, and California to name a few. Residential consumers in these states are urged to use a large, sturdy plastic or wax-coated leak-proof container to hold the FOG until full, and the city provides a drop-off location for containers. If, at a later point, additional feedstock material is required or needed, residential household kitchen waste can be considered.

\subsection{Digester feed mixtures}

\subsubsection{Handling the high volume of waste-activated sludge}

As discussed above, the Fort Huachuca AD system was designed to process the sludge from trickling filters. The volume of waste-activated sludge (WAS) from the oxidation ditch (the current process) is too large for the current capacity of the $\mathrm{AD}$ tanks (i.e., the tanks are too small to provide adequate residence time). In other words, the WAS is too dilute at $1 \%$ solids for effective $\mathrm{AD}$, as the process requires $5 \%$ to $10 \%$ solids to provide enough organic material for the microbes to metabolize. One option is to use the existing belt press to eliminate excess water. In addition to boosting solids, this option would make the overall process more energy efficient because it would limit the volume of liquid that must be heated to bring the digesters to the required temperature of at least $100{ }^{\circ} \mathrm{F}$.

\subsubsection{Different anaerobic digester systems}

As described in Appendix B on AD systems, there are many possible configurations. The most common type of $\mathrm{AD}$ is the single-phase system, where all of the microbial degradation of organics occurs in the same tank. 
Single-phase is the original configuration of the AD system at Fort Huachuca.

A newer alternative consists of a two-phase system, as described in Appendix B. Potentially, the existing Fort Huachuca AD system can be adapted to a two-phase system by adding a relatively small acidification tank as the first of three tanks. The second tank will be the current first tank, where the majority of methane will be formed, and the last tank will remain as the final rest tank. The two separate types of microbes (acid and methane) are hosted and optimized in their respective tanks. The potential benefits of this approach are:

- higher organics degradation,

- quicker throughput, and

- greater net energy recovery.

Some adjustments need to be made to develop a "recipe" of digester infeed that meets both the volume restrictions of the existing tanks and increases the net solids content. Five scenarios (below) were developed to meet these criteria in a two-phase system. In addition, a sixth scenario was derived for a single-phase system, which is presented in the modeling section of Appendix D.

\subsubsection{Digester inputs}

Five sets of organic feedstock inputs or scenarios were explored to scope the feasibility of adding all or part of Fort Huachuca's organic waste to the digester for energy recovery. The scenarios here focus on volumes of material vs. capacity of the $\mathrm{AD}$ tanks. The main variable is the quantity and thickness of biosolids introduced to the digesters. Later in the modeling section, we will show expected energy recovery and net income. The five two-phase scenarios are presented in Table 3.

Table 3. AD feedstock scenarios (ERDC-CERL).

\begin{tabular}{|l|l|l|l|l|l|}
\hline Parameter & Scenario 1 & Scenario 2 & Scenario 3 & Scenario 4 & Scenario 5 \\
\hline Description & $\begin{array}{l}\text { All food waste, } \\
\text { oil, grease, and } \\
\text { WAS (as is) }\end{array}$ & $\begin{array}{l}\text { Dry all WAS to 2\% } \\
\text { solids }\end{array}$ & $\begin{array}{l}\text { Dry all WAS to 5\%. } \\
\text { For added organic } \\
\text { wastes, add } \\
\text { reclaimed water to } \\
\text { dilute to 5\%. }\end{array}$ & $\begin{array}{l}\text { Landfill half of the } \\
\text { WAS; use the } \\
\text { remainder at 0.5\% } \\
\text { to dilute incoming } \\
\text { food. }\end{array}$ & Dry all WAS to 1\% \\
\hline WAS, gal/day & 30,000 @ 0.5\% & 7,650 @ 2\% & $3,000 @ 5 \%$ & 15,000 @ 0.5\% & 15,150 \\
\hline Grease, gal/day & 548 & 548 & 548 & 548 & 548 \\
\hline
\end{tabular}




\begin{tabular}{|c|c|c|c|c|c|}
\hline Parameter & Scenario 1 & Scenario 2 & Scenario 3 & Scenario 4 & Scenario 5 \\
\hline $\begin{array}{l}\text { Cooking oil, } \\
\text { gal/day }\end{array}$ & 400 & 400 & 400 & 400 & 400 \\
\hline DFAC food, gal/day & 400 & 400 & 400 & 400 & 400 \\
\hline $\begin{array}{l}\text { Other food, } \\
\text { gal/day }\end{array}$ & 450 & 450 & 450 & 450 & 450 \\
\hline $\begin{array}{l}\text { Horse manure, } \\
\text { gal/day }\end{array}$ & 300 & 300 & 300 & 300 & 300 \\
\hline $\begin{array}{l}\text { Added water, } \\
\text { gal/day }\end{array}$ & 0 & 0 & 14,500 & 0 & 0 \\
\hline $\begin{array}{l}\text { Overall input, \% } \\
\text { solids }\end{array}$ & $3.3 \%$ & $10.8 \%$ & $5.4 \%$ & $5.7 \%$ & $6.1 \%$ \\
\hline $\begin{array}{l}\text { Hydraulic retention } \\
\text { time (HRT) in main } \\
\text { digester, days (15 } \\
\text { days or more is } \\
\text { desirable) }\end{array}$ & 7.8 & 25 & 12.5 & 14.7 & 14.7 \\
\hline Notes & $\begin{array}{l}\text { Not feasible; } \\
\text { WAS too dilute, } \\
\text { too much } \\
\text { volume. HRT too } \\
\text { low. }\end{array}$ & $\begin{array}{l}\text { Okay, but must } \\
\text { have steady } \\
\text { supply of food, } \\
\text { oil, and grease. }\end{array}$ & $\begin{array}{l}\text { At } 5.4 \% \text { solids, this } \\
\text { is the lower limit at } \\
\text { which a digester } \\
\text { can be operated. } \\
\text { The benefit of this } \\
\text { scenario is that it's } \\
\text { not reliant on food } \\
\text { supply. Note that } \\
\text { the reclaimed } \\
\text { water input would } \\
\text { simply recycle back } \\
\text { to the headworks. }\end{array}$ & $\begin{array}{l}\text { Technically } \\
\text { possible, but not } \\
\text { desirable due to } \\
\text { expense of } \\
\text { landfilling } 50 \% \\
\text { WAS and losing } \\
\text { that energy } \\
\text { content. See the } \\
\text { modeling section } \\
\text { of Appendix D }\end{array}$ & $\begin{array}{l}\text { This would work, } \\
\text { but Scenario } 2 \\
\text { would be a better } \\
\text { option if drying } \\
\text { the WAS. }\end{array}$ \\
\hline
\end{tabular}




\section{Co-Digestion Economic Analysis Tool (COEAT)}

\subsection{Model description}

The Co-Digestion Economic Analysis Tool (CoEAT) provides an initial economic and physical feasibility assessment of organic waste co-digestion at WWTPs for the purpose of biogas production. For model input data see Appendix D.

The CoEAT uses the current publicly available data on the emerging practice of co-digestion at WWTPs. CoEAT does not require pre-existing WWTP digesters, and it will calculate results with no pre-existing digester in place; however, the model was intended to help WWTP operators assess the viability of implementing co-digestion with existing anaerobic digesters. Because empirical data are not available for a wide variety of food waste co-digestion projects in the United States, the model uses the best current data and should be considered a screening tool for initial evaluation.

CoEAT does not provide a rigorous feasibility study, but it does identify the various logistical, operational, and equipment considerations within an "economic cost model," resulting in the calculation of the net annual worth of the project. The CoEAT model is flexible, and users can adjust assumptions and costs to fit the circumstances. Wherever available, source data is provided for further research and evaluation. For the best results, users should input specific operating parameters instead of using model assumptions.

CoEAT calculates the economic, environmental, and operational outputs for an organic waste co-digestion system, including:

- fixed and recurring costs,

- solid waste diversion savings,

- capital investments,

- biogas production, and

- avoided utility/vehicle fuel costs. 
The types of organic waste considered as part of this model include:

- food waste;

- fats, oils, and grease; and

- other organic feedstock if the user has minimal information on feedstock characteristics.

Figure 9 graphically depicts the operations and costs that are considered part of the tool.

This tool models wet digestion and should not be used as a proxy for determining the feasibility of dry digestion. Key components which are not included as part of the tool are:

- off-site preprocessing of feedstock,

- biogas air emission reductions,

- greenhouse gas emission reductions from renewable energy generation, and

- avoided transportation costs to landfill.

Figure 9. Schematic of Co-Digestion Economic Analysis Tool (CoEAT), identifying key components of the model (U.S. EPA Office of Research and Development [ORD]).

\begin{tabular}{|c|c|c|}
\hline $\begin{array}{l}\text { Feedstock Characteristics } \\
\text { - Food Waste } \\
\text { - Fats, Oils, \& Grease (FOG) } \\
\text { Feedstock Receiving } \\
\text { - Landfill Tipping Fees } \\
\text { - Tipping Fee at Digester } \\
\text { Feedstock Processing } \\
\text { - Equipment } \\
\text { - Operations \& Maintenance }\end{array}$ & $\begin{array}{l}\text { Digester Infrastructure } \\
\text { - Excess Capacity } \\
\text { - Needed Capacity } \\
\text { - Acillary Equipment } \\
\text { Operations \& } \\
\text { Maintenance } \\
\text { - Repari, cleaning, etc. } \\
\text { - Labor } \\
\text { - Operating Parameters }\end{array}$ & $\begin{array}{l}\text { - Transportation } \\
\text { - Tipping Fees } \\
\text { Biogas } \\
\text { Quantity } \\
\text { Value } \\
\text { - Heating } \\
\text { - Rembined Heat and Power (CHP) } \\
\text { Cleaning }\end{array}$ \\
\hline
\end{tabular}




\subsection{Modeling food waste AD scenarios}

\subsubsection{General assumptions}

Table 7 depicts the results from the modeling efforts that quantify the operations and costs of multiple organic waste input "scenarios," as developed for two-phase AD (Appendix B). For this modeling exercise, a onephase system was included as a comparison, the benefits of which are discussed in Scenario 6 below.

To model the different scenarios based on biogas use output option B (biogas used for combined heat and power [CHP]), the input variable for "Time of Use" must be set to future for all feedstocks. The VS/TS (volatile solids/total solids) ratios used are the default values in the model. The assumed specific gravity for all feedstocks is 1 . This will be the value used in the model. The VS/TS ratio for horse manure is assumed to be the same as primary sludge (0.8).

\subsubsection{Scenario 1-6 assumptions}

\section{Scenario 1 assumptions and inputs}

The future percent solids of homogenized feedstock and HRT were set equal to the calculated values in the "recipes" worksheet (i.e., the list of feedstock scenarios). The provided feedstock parameters for "Scenario 1" were input into the model. The cost for the acid tank was calculated using a conversion factor of $\$ 27 / \mathrm{ft} 3$ for a $6,016 \mathrm{ft} 3$ tank.

The model is equipped to calculate the heating demand for multiple tanks all of the same size and operating temperature. In this case, there are two tanks operating at separate temperatures and different sizes. An equivalent surface area and weighted operating temperature were calculated to input into the model. The calculations for the equivalent surface area and weighted operating temperature can be found below. The input variables for the model are in Appendix E.

\section{Scenario 2 assumptions and inputs}

The future percent solids of homogenized feedstock and HRT were set equal to the calculated values in the "recipes" worksheet. The provided feedstock parameters for Scenario 2 were input into the model. The cost 
for the acid tank was calculated using a conversion factor of $\$ 27 / \mathrm{ft} 3$ for a $2,005 \mathrm{ft}^{3} \operatorname{tank}$.

Similarly, an equivalent surface area and weighted operating temperature were calculated and input into the model. The calculations for the equivalent surface area and weighted operating temperature can be found below. The input variables for the model are in Appendix E.

\section{Scenario 3 assumptions and inputs}

The future percent solids of homogenized feedstock and HRT were set equal to the calculated values in the "recipes" worksheet for the total feedstock calculation. The feedstocks were kept the same as scenario 2 because the assumption is that this is how the feedstocks are received. By setting the percent solids of homogenized feedstock to the calculated value, tipping fees and total amount heated are calculated correctly. The cost for the acid tank was calculated using a conversion factor of $\$ 27 / \mathrm{ft} 3$ for a $4,010 \mathrm{ft}^{3}$ tank.

Similarly, an equivalent surface area and weighted operating temperature were calculated and input into the model. The calculations for the equivalent surface area and weighted operating temperature can be found below. The input variables for the model are in Appendix E.

\section{Scenario 4 assumptions and inputs}

The future percent solids of homogenized feedstock and HRT were set equal to the calculated values in the "recipes" worksheet. The provided feedstock parameters for Scenario 4 were input into Co-EAT. The cost for the acid tank was calculated using a conversion factor of $\$ 27 / \mathrm{ft} 3$ for 3,342 $\mathrm{ft} 3$. This scenario only models half of the WAS generated, therefore, it only calculates cost of disposal for half of the total solids in the WAS stream. The cost of disposal is much higher than calculated. There is also a decrease in biogas production resulting in a lower value of the biogas.

Adjustment: The following steps were taken in the model to account for the non-anaerobically digested WAS:

1. Change Feedstock \#1 (WAS)'s "Time of Use" to Future.

2. Create Feedstock \#7 (WAS) and set its "Time of Use" to Current, using the same feedstock parameters as Feedstock \#1. 
3. Set "Current \%VS Reduction" equal to zero (WAS does not have any further solids reduction treatment).

4. Add the "Mass of Biosolids" and "Biosolids Cost" for Current and Scenario B in the "3. Comparison" worksheet to calculate the total biosolids cost and generation.

5. Assume that the percent solids and disposal cost per ton of the nontreated WAS and digestate are equal.

Similarly, an equivalent surface area and weighted operating temperature were calculated and input into the model. The calculations for the equivalent surface area and weighted operating temperature can be found below. The input variables for the model are in Appendix E.

\section{Scenario 5 assumptions and inputs}

The future percent solids of homogenized feedstock and HRT were set equal to the calculated values in the "recipes" worksheet. The provided feedstock parameters for Scenario 5 were input into model. The cost for the acid tank was calculated using a conversion factor of $\$ 27 / \mathrm{ft}^{3}$ for $3,342 \mathrm{ft}^{3}$.

Similarly, an equivalent surface area and weighted operating temperature were calculated and input into the model. The calculations for the equivalent surface area and weighted operating temperature can be found below. The input variables for the model are in Appendix E.

\section{Scenario 6 assumptions and inputs}

While the above scenarios assumed a two-phase AD system, Scenario 6 is presented as a simpler alternative because no additional tanks are needed. In this scenario, a single stage system is being modeled at mesophilic temperatures $\left(98^{\circ} \mathrm{F}\right)$. The future percent solids of homogenized feedstock was set equal to $6.1 \%$ with an HRT of 15 days. The feedstock inputs are equal to Scenario 5. The provided feedstock parameters for Scenario 5 were input into model. The need for food waste grinding and mixture is still necessary and is costed at the same size as Scenario 5. The cost for the buffer tank is significantly less than a digester and the conversion factor used was $\$ 9 / \mathrm{ft}^{3}$ for $3,342 \mathrm{ft} 3$.

Heating is only required for one tank for Scenario 6. Calculations for all scenarios are in Table 4. 
The Co-EAT runs for Scenarios 5 and 6 have determined that a two stage system is no more efficient than a single stage system in regards to the conversion of organic solids into biogas. With heating demand having the greatest influence on biogas value, a reduction in heating demand will have the greatest effect on the net annualized value. A method that would reduce the heating demand is to switch from a two temperature phased system to a single stage system. A two stage system operating at both thermophilic $\left(120^{\circ} \mathrm{F}\right.$ acid tank) and mesophilic ( $98^{\circ} \mathrm{F}$ methane tank) temperatures requires more energy to maintain the operating temperatures rather than a single stage system with one tank operating at mesophilic temperatures. Also, the two stage system compared to a single stage system requires a greater amount of energy for initial feedstock heating because you have to raise the temperature of all feedstock to $120^{\circ} \mathrm{F}$ rather than $98^{\circ} \mathrm{F}$. A single stage system would greatly decrease the heating demand giving the excess heat more value. The single stage scenario, Scenario 6, was modeled in Co-EAT using the same inputs as Scenario 5 except for operating temperature, surface area, and max feedstock temperature. By converting to a single-stage system, the heating demand and net annualized value changes from 4,636 to 3,079 MBTU/yr. and from $\$ 149,358$ to $\$ 175,889$, respectively, concluding that a single-stage system is the more favorable design in regards to heating demand and net annualized value.

\subsection{Model scenario results}

Results recorded in Scenarios 1-6 are summarized in Table 4. 
Table 4. Scenario modeling results (ERDC-CERL).

\begin{tabular}{|c|c|c|c|c|c|c|}
\hline & Scenario 1 & Scenario 2 & Scenario 3 & Scenario 4 & Scenario 5 & Scenario 6 \\
\hline Biogas produced $\left(\mathrm{ft}^{3} / \mathrm{yr}\right)$ & $25,428,376$ & $25,490,019$ & $25,490,019$ & $23,887,300$ & $25,459,197$ & $25,459,197$ \\
\hline Total biogas heating energy (MBTU/yr) & 7,404 & 7,422 & 7,422 & 6,955 & 7,413 & 7,413 \\
\hline Total energy needed for heating (MBTU/yr) & 7,543 & 3,164 & 5,097 & 4,615 & 4,636 & 3,079 \\
\hline Max capacity of digester (gal) & 0 & 0 & 0 & 0 & 0 & 0 \\
\hline Feedstock feed rate (gal/day) & 32,075 & 9,739 & 19,479 & 17,085 & 17,219 & 17,219 \\
\hline Percent solids of feedstock fed to digester (\%) & $3.3 \%$ & $10.8 \%$ & $5.4 \%$ & $5.7 \%$ & $6.1 \%$ & $6.1 \%$ \\
\hline Percent volatile solids reduction (\%) & $60 \%$ & $60 \%$ & $60 \%$ & $60 \%$ & $60 \%$ & $60 \%$ \\
\hline Actual hydraulic retention time (days) & 0.0 & 0.0 & 0.0 & 0.0 & 0.0 & 0.0 \\
\hline Target hydraulic retention time (days) & 9.2 & 26.5 & 14.0 & 16.2 & 16.2 & 15.0 \\
\hline Available capacity (gal/day) & 0 & 0 & 0 & 0 & 0 & 0 \\
\hline $\begin{array}{l}\text { Additional volume needed to treat feedstock } \\
\text { (gal) }\end{array}$ & 295,090 & 258,093 & 272,702 & 276,779 & 278,946 & 258,283 \\
\hline Mass of biosolids (tons/yr) & 4680 & 4696 & 4696 & 5001 & 4688 & 4688 \\
\hline Biosolids cost $(\$ / y r)$ & $(\$ 163,798)$ & $(\$ 164,348)$ & $(\$ 164,348)$ & $(\$ 175,035)$ & $(\$ 164,073)$ & $(\$ 164,073)$ \\
\hline Biosolids revenue $(\$ / y r)$ & $\$ 0.00$ & $\$ 0.00$ & $\$ 0.00$ & $\$ 0.00$ & $\$ 0.00$ & $\$ 0.00$ \\
\hline Tipping fees $(\$ / y r)$ & $\$ 268,019.50$ & $\$ 268,019.50$ & $\$ 268,019.50$ & $\$ 268,019.50$ & $\$ 268,019.50$ & $\$ 268,019.50$ \\
\hline Avoided natural gas costs $(\$ / y r)$ & $(\$ 1,814)$ & $\$ 55,536$ & $\$ 30,324$ & $\$ 30,524$ & $\$ 36,220$ & $\$ 56,528$ \\
\hline Avoided electricity costs $(\$ / y r)$ & $\$ 107,590$ & $\$ 107,851$ & $\$ 107,851$ & $\$ 101,069$ & $\$ 107,720$ & $\$ 107,720$ \\
\hline Avoided vehicle fuel (\$/yr) & $\$ 0$ & $\$ 0$ & $\$ 0$ & $\$ 0$ & $\$ 0$ & $\$ 0$ \\
\hline Annualized cost of plant upgrades (\$/yr) & $(\$ 105,904)$ & $(\$ 94,885)$ & $(\$ 100,485)$ & $(\$ 93,909)$ & $(\$ 98,528)$ & $(\$ 92,305)$ \\
\hline Annual operations and maintenance $(\$ / y r)$ & $\$ 0$ & $\$ 0$ & $\$ 0$ & $\$ 0$ & $\$ 0$ & $\$ 0$ \\
\hline Net Annualized Value (\$/yr) & $\$ 104,093$ & $\$ 172,174$ & $\$ 141,361$ & $\$ 130,669$ & $\$ 149,358$ & $\$ 175,889$ \\
\hline
\end{tabular}




\subsection{Fort Huachuca model conclusions}

One of the primary goals for considering upgrades at the Fort Huachuca's WWTP is to make the plant self-reliant in terms of energy. To become selfreliant, the facility must generate the necessary heat and electrical energy needed for its daily operations. Many biogas use options are available, with each one generating different and/or multiple forms of energy. The requirement to produce both electrical and heat energy influenced the decision to use a biogas-driven generator with heat and electricity recovery, commonly referred to as a CHP engine, as the primary use of biogas.

CoEAT was used to model and compare the economics and physical parameters of the $\mathrm{AD}$ process, using a CHP for energy recovery for the multiple feedstock scenarios listed in section 5.2.2. The scenarios provide two primary comparisons. First is the comparison of altering the percent solids of the feedstock fed to the digester (Scenarios 1, 2, 3, and 5). The second is reducing the amount of WAS fed, so that when it is mixed with the other feedstocks the mixed feedstock is at an operable percent solids (Scenario 4 compared to all other scenarios). In the first primary comparison, there is no change between the scenarios in the amount of solids fed to the digester; there is only a change in the total volume of feedstock. In the second primary comparison, there is a change in the total amount of solids sent to the digester as compared to the other four scenarios. This change is important because the solids sent to the digester are responsible for biogas and biosolids production-the two major factors in costs and savings.

The input variables for each scenario can be found in Appendix D. The results for each of the scenarios can be seen in Table 4. Three main conclusions are:

1. The higher the percent solids fed to the digester, the lower the total heating energy needed. The more solids, the less water and therefore, the less water to heat. The less water, the less water that needs to be heated and the smaller the tanks needed to store the feedstocks.

2. The percent solids fed to the digester has a direct relation to the net annualized value.

3. All WAS should be fed to the digesters to maximize biogas production and decrease total biosolids volume.

Co-EAT calculates the total heating demand by summing the amount of energy needed to increase incoming feedstock to operating temperatures 
and the amount of energy lost through the walls of the digesters. The effect of percent solids of the mixed feedstock on heating demand can be seen by comparing the results of Scenarios 1, 2, 3, and 5 in Table 4. As percent solids decrease, the total amount of energy needed for heating decreases as displayed in Figure 10. Increasing the percent solids reduces the total daily volume added to the digester. By decreasing the total daily volume of feedstock, there is less feedstock that needs initial heating and the size of the tanks decrease. Reducing the size of the tanks reduces the surface area and, in-turn, reduces the amount of heat needed to maintain the digester's operating temperature. By increasing the percent solids of the feedstock, the amount of energy required for both heat demand calculations is decreased.

Figure 10. Total heating demand vs. percent solids of mixed feedstock (U.S. EPA ORD).

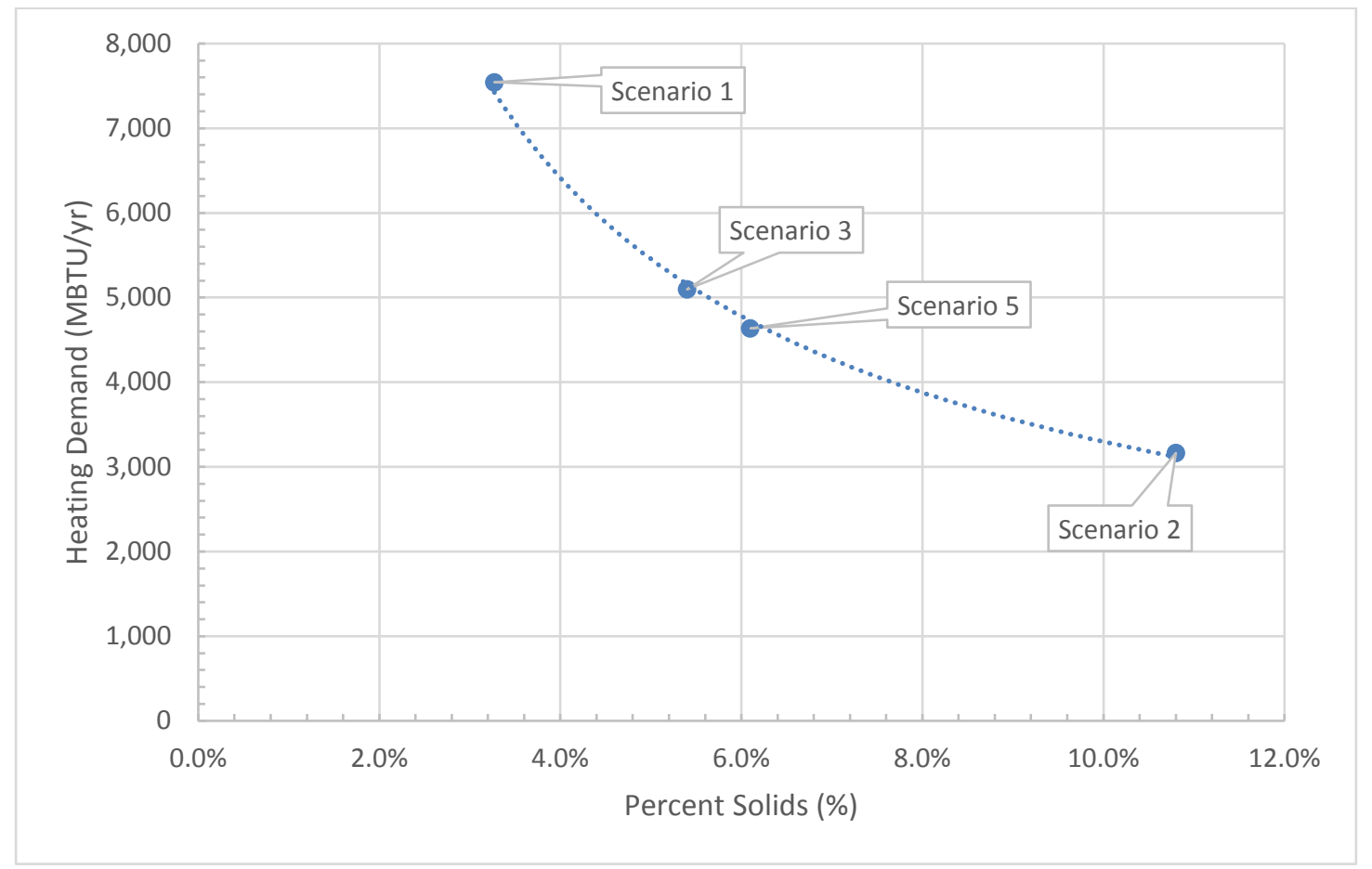

The model associates costs with biosolids disposal, plant upgrades and additions, supplemental natural gas to meet heating demand of digester (if necessary), and annual operations and maintenance. These are unknown so are set to o for each scenario. The positive cash flow includes avoided utility costs and revenue from tipping fees. Avoided utility costs using a CHP include avoided natural gas costs and avoided electricity costs. As described before, the total amount of solids fed to the digester for Scenarios $1,2,3$, and 5 are approximately equal. A slight error exists due to rounding 
in calculations for percent solids in the above listed scenarios. Biogas production and biosolids generation are dependent on the total solids of the mixed feedstock and $\mathrm{AD}$ performance metrics (e.g., percent volatile solids reduction and biogas production rate). Without changing any of the performance metrics between the four scenarios and adding the same amount of solids for each scenario, biogas production and biosolids generation are approximately equal across the scenarios.

Scenarios 1, 2, 3, and 5 have very similar total biogas energy because of the approximately equal biogas production. This means that the total amount of heat energy recovered from the CHP is equal and avoided electricity costs are equal. The same is true for biosolids generation. Since each of these scenarios have the same biosolids generation, they have the same biosolids disposal costs. Each scenario receives the same amount of external feedstock, so the tipping fees are equal. In Fort Huachuca's case, the tipping fees for the organic wastes were set equal to the current disposal costs of these wastes, effectively resulting in an avoided disposal cost. The remaining costs and avoided costs of plant upgrades and additions and supplemental/avoided natural gas costs are not affected by biogas production and biosolids generation. Rather, these cash flows are related to the percent solids of the mixed feedstock.

As discussed above, the percent solids of the mixed feedstock is the factor that affects the volume of feedstock. The volume of feedstock determines the tank size and energy demand. A decrease in tank size decreases the total cost of constructing an acid tank/mixing tank. Increasing the feedstock volume (decreasing percent solids of mixed feedstock) increases the energy demand. Avoided natural gas costs are calculated by taking the difference between the total amount of heat energy recovered from the CHP and the heat energy demand. The difference is then converted into a natural gas equivalent. If the value is negative, the value is supplemental heat energy. When the value is positive, it is avoided natural gas costs. Therefore, percent solids of the mixed feedstock is directly related to the net annualized value and can be seen in Figure 11. 
Figure 11. Net annual value vs. percent solids (U.S. EPA, ORD).

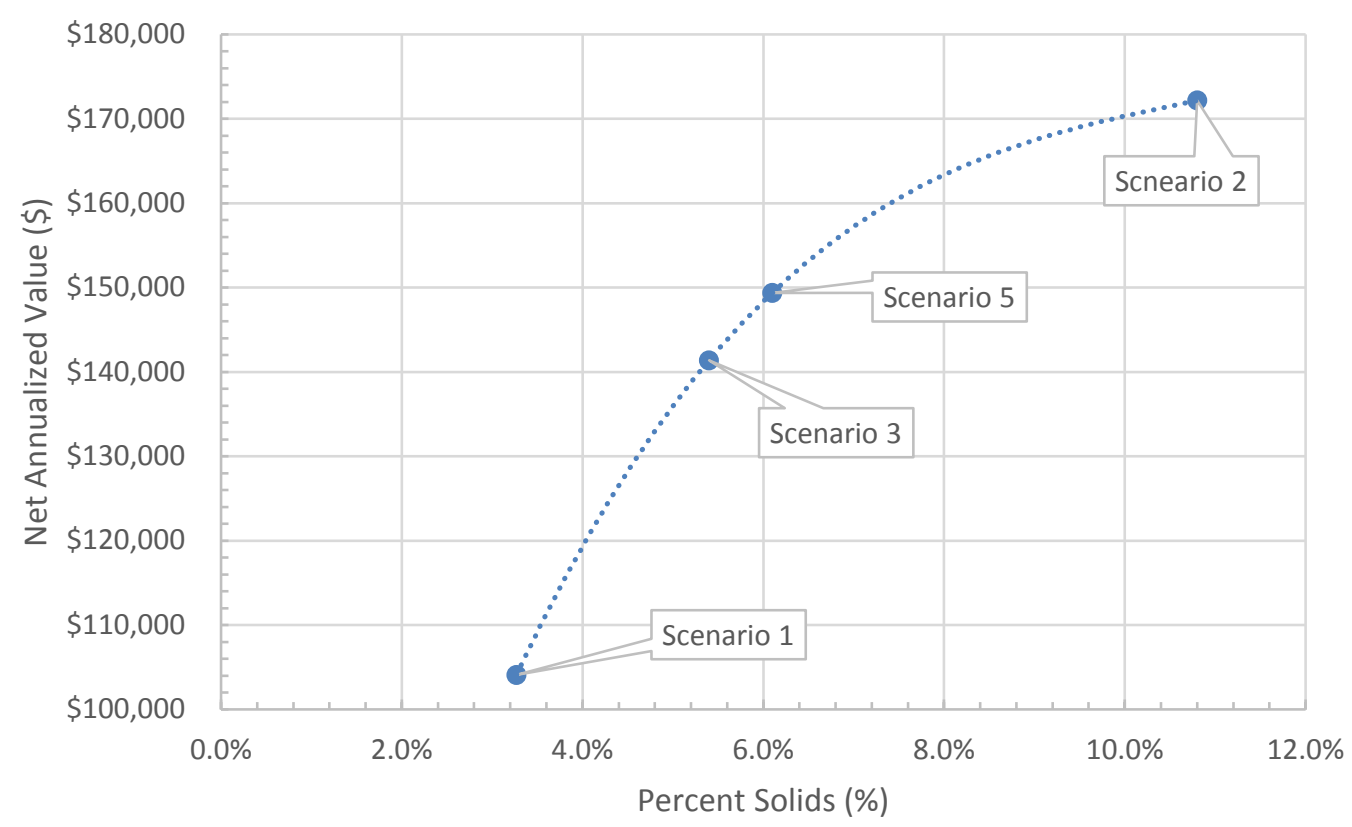

Scenario 4 was the only scenario that reduced the total amount of solids fed to the digester by decreasing by half the amount of fed WAS. External feedstocks were kept the same. This decrease in solids added to the digester decreased biogas production from approximately 25.4 to 23.9 million $\mathrm{ft} 3$ per year. This decrease reduces the value of electrical energy from approximately $\$ 107,700$ to $\$ 101,000$ per year. The avoided natural gas cost remains equivalent to Scenarios 2, 3, and 5. There is also an increase in biosolids disposal costs. By adding half the solids from the WAS to the digester, only half are being further reduced and the undigested solids still need to be disposed. This situation increases the cost of disposal from approximately $\$ 164,000$ to $\$ 175,000$ per year. The model results for Scenario 4 can be seen in Table 4. The comparison of results between Scenario 4 and Scenarios 1, 2, 3, and 5 determined that, by only adding half of the WAS, the value of biogas decreases and the cost of biosolids disposal increases. Scenario 4 is an unfavorable alternative.

The following general recommendations have been derived from the CoEAT results:

- Co-digest all WAS.

- Operate digesters at the highest percent solids possible.

- Use a simple single stage system. 
- Implement digester stability metrics to optimize performance (i.e., VFA [volatile fatty acids]/TIC [total inorganic carbon] ratio).

- Operate digester at no less than $6.5 \%$ solids for the single-stage process (required solids percentage to not exceed current tank capacity).

Co-EAT allows analysis of options and points toward an understanding of the economics of making changes in the $\mathrm{AD}$ system at Fort Huachuca. The recommendations in this report are the results of running multiple scenarios, with an understanding that the reality of the system after the design changes will be different than any of the scenarios considered. The costs in this report are estimates. The amount of food waste available will change. The rates for landfill tipping and utilities will change over time. Even given those uncertainties, it is still clear that spending the needed funds to remodel the AD system to accept food waste, mixed with the facility's activated sludge, is a solid investment that will pay for itself relatively quickly. Accepting food waste will also help the installation move closer to its net zero goals, making it perhaps the first Army installation to do so using an on-installation $\mathrm{AD}$ system with food waste. 


\section{Proposed Investments for Potential Co- Digestion Operation}

\subsection{Currently available hardware}

The anaerobic digester at Fort Huachuca was built over 50 years ago. It was originally designed to digest wastewater sludge from the trickling filter at the WWTP. Digested sludge was put on drying beds for later use as a general-purpose soil amendment. The two, 250,000 gallon digester tanks are installed in series. Currently, both tanks are off-line, and the sludge from the WWTP is being sent through a mechanical belt press and dewatered prior to sending to the landfill. As shown in Figure 12, wastewater sludge is being pumped directly from the clarifier into the mechanical belt press. It was reported by the installation that the sludge comes out of the clarifier with 1 to $2 \%$ of solids and, after undergoing the belt press, it would be left with $17 \%$ solids.

Figure 12. Existing process flow diagram of WWTP of Fort Huachuca, AZ (All Star 2012, modified by ERDC-CERL).

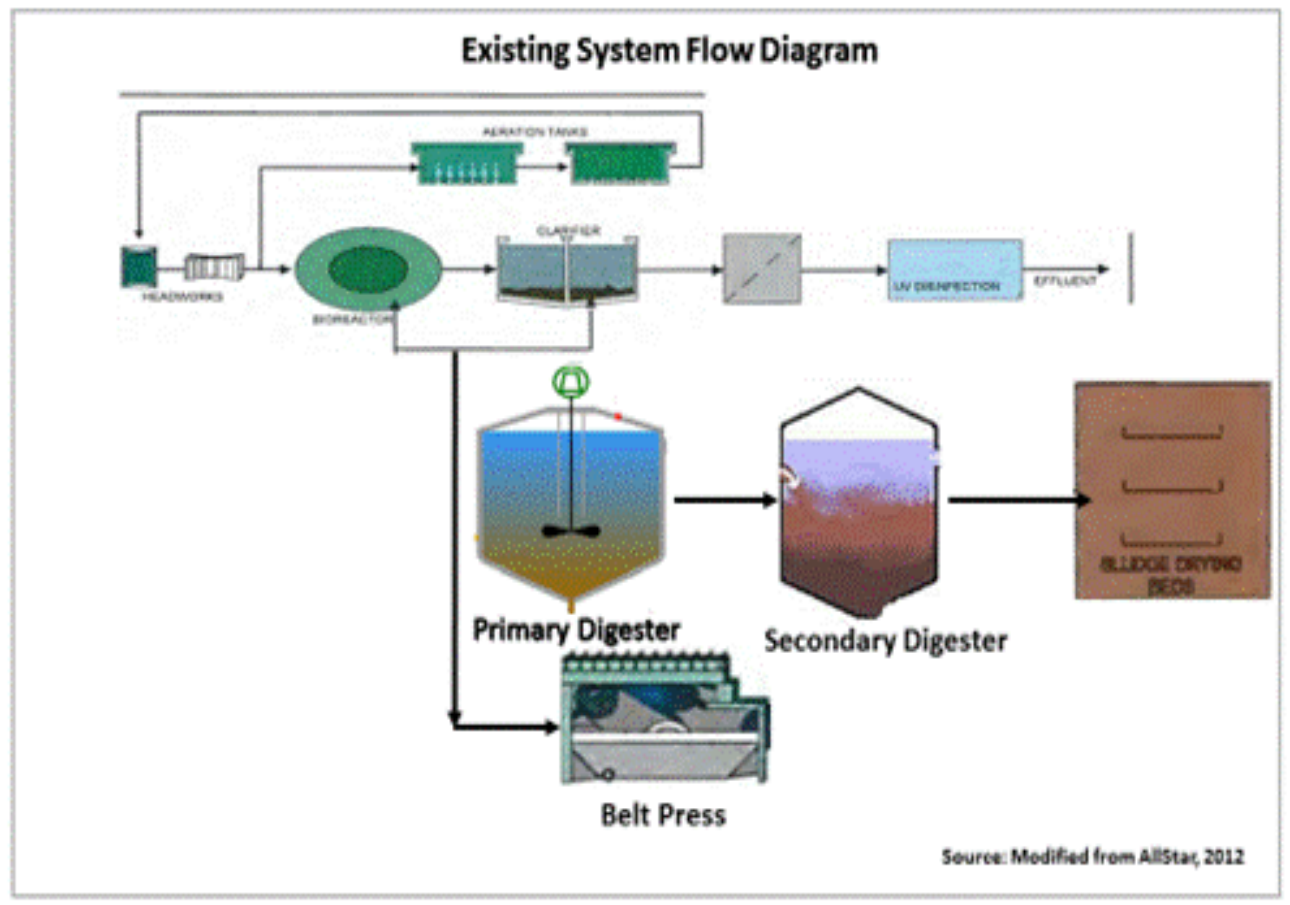

The Fort Huachuca WWTP is operated under contract with All Star Technical Services, Inc. (All Star). In June 2011, the primary anaerobic digester was outfitted with a replacement dual-membrane cover system (Figure 
13). However, soon afterward, All Star experienced operational issues with the new membrane system and, for safety concerns of digester gas leakage, ceased AD operations. Greeley and Hansen ${ }^{3}$ was commissioned by All Star to investigate the membrane cover issue, and they published "Anaerobic Digester Membrane Cover Investigation and Report” (All Star 2012).

Figure 13. Dual-membrane digester, showing layering of membrane covers (Natural Systems Utilities 2015).

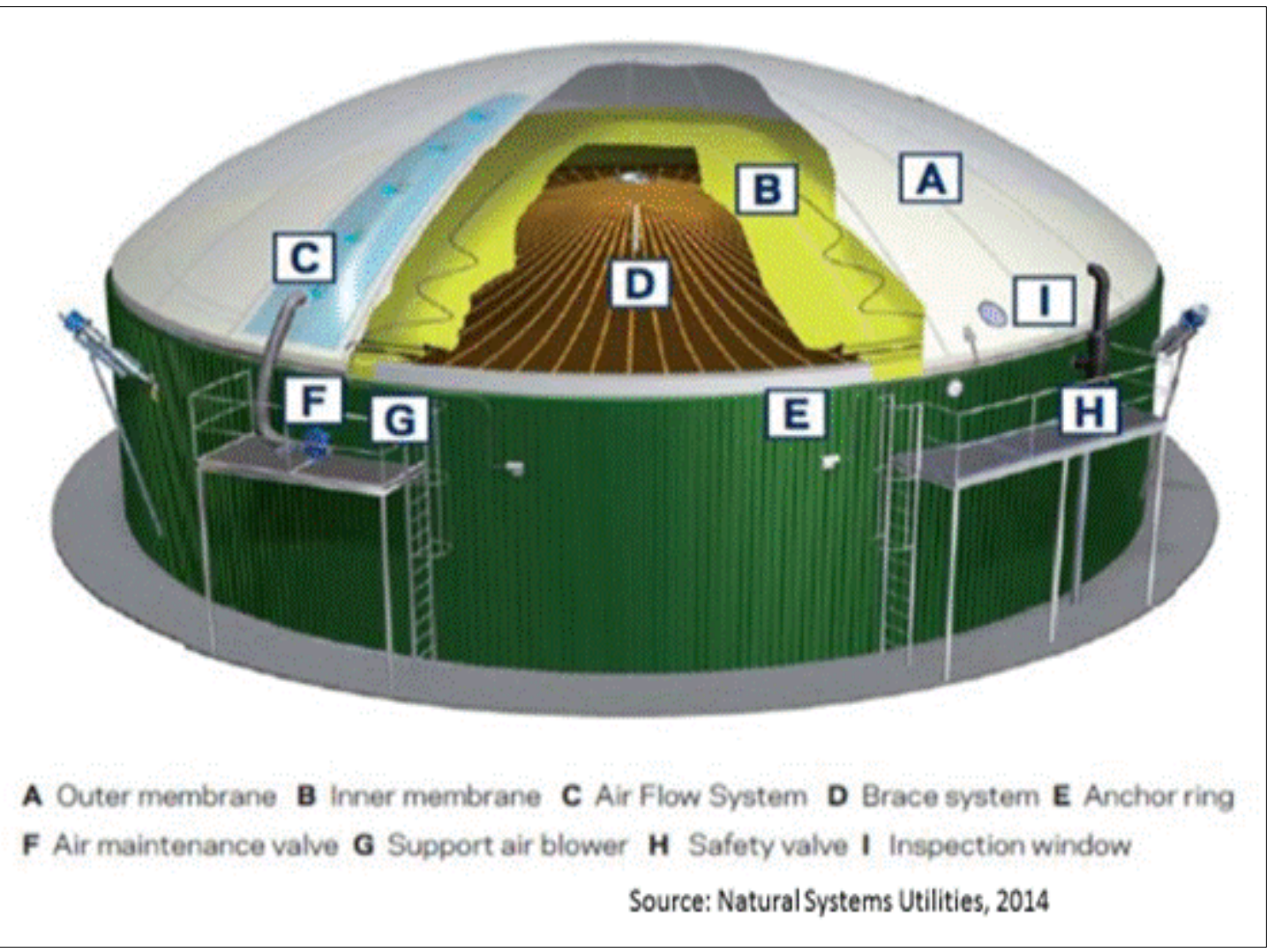

As mentioned in the All Star 2012 report, the center of the digester is a circular platform structure that supports the internal mixing system for the digester. In order to form a gas-tight seal, the membranes are also attached to this mixing platform. When the membrane system is fully inflated, the tank cover takes the shape of a one-half torus (like a doughnut sliced in half). During normal operating conditions, the inner membrane is supposed to capture digester gas completely, and there should not be any leakage since the outer membrane is sealed. However, as a safety precaution in response to the observation that hydrogen sulfide was discharging from a gas detection exhaust port, operations were halted. Greeley and

\footnotetext{
${ }^{3}$ An engineering consulting firm associated with water, wastewater, and solid waste that is headquartered in Chicago, IL.
} 
Hansen began its digester performance evaluation on 1 May 2012 and continued through 30 June 2012. Several parameters were measured and monitored by operations staff during the 60-day performance evaluation. Because hydrogen sulfide was detected at the exhaust port, they suspected that the inner membrane was ruptured and leaking hydrogen sulfide gas into the space between the inner and outer membranes. However, while the performance evaluation did not rule out a small leak, it did suggest that the inner membrane was not ruptured.

The manufacturer of the membrane, WesTech,4 indicated that on other projects they have experienced hydrogen sulfide diffusion through the inner membrane. This could explain the presence of hydrogen sulfide, but does not explain why there is no methane diffusion through the membrane. During the 60-day performance evaluation period, the digester did not appear to generate or capture sufficient volumes of digester gas in the inner membrane of the system. Therefore, the investigators could not conclusively determine that the inner membrane was ruptured; thus the source of "leak" remained unresolved.

The performance evaluation recommended testing the integrity of the inner membrane. Evaluators suggested testing the system by raising the inner membrane above the sludge surface and inserting an inert gas into the digester through the digester gas piping system. Until the issue of the gas leak was resolved, the evaluators recommended discontinuing operations of the anaerobic digester.

\subsection{Investment considerations for current system}

Considering the amount of sludge generated daily at the WWTP and the amount of food waste generated at Fort Huachuca, it is evident that with some modifications to the existing anaerobic digesters, the sludge and food waste can be put to more productive use and save landfill space and tipping fees. However, until the leak or ruptured inner membrane is verified, investment in co-digestion is not recommended. As per conversation

\footnotetext{
${ }^{4}$ WesTech is headquartered in Salt Lake City, Utah. The company engineers and manufactures process equipment for customers in the industrial, mineral, municipal water, and municipal wastewater industries.
} 
with WesTech on 23 September 2016,5 replacing the dual-membrane cover will cost approximately $\$ 106,600$.

If co-digestion of food waste is implemented, other investments are recommended to ensure efficient operation of the tanks. If the two-phase $\mathrm{AD}$ system is pursued, it is recommended that another 45,000-gallon tank is installed ahead of the existing primary tank. This would allow for the separation of the acid phase from the methane phase, making each more efficient.

To facilitate incoming food, a staging area is required as well as a food grinder, also mentioned above, to break down food before it goes into the digesters and jump-start the digestion process. A potential two-phase system's flow diagram is depicted in Figure 14.

Figure 14. Potential two-phase WWTP process flow diagram at Fort Huachuca (All Star 2012, modified by ERDC-CERL).

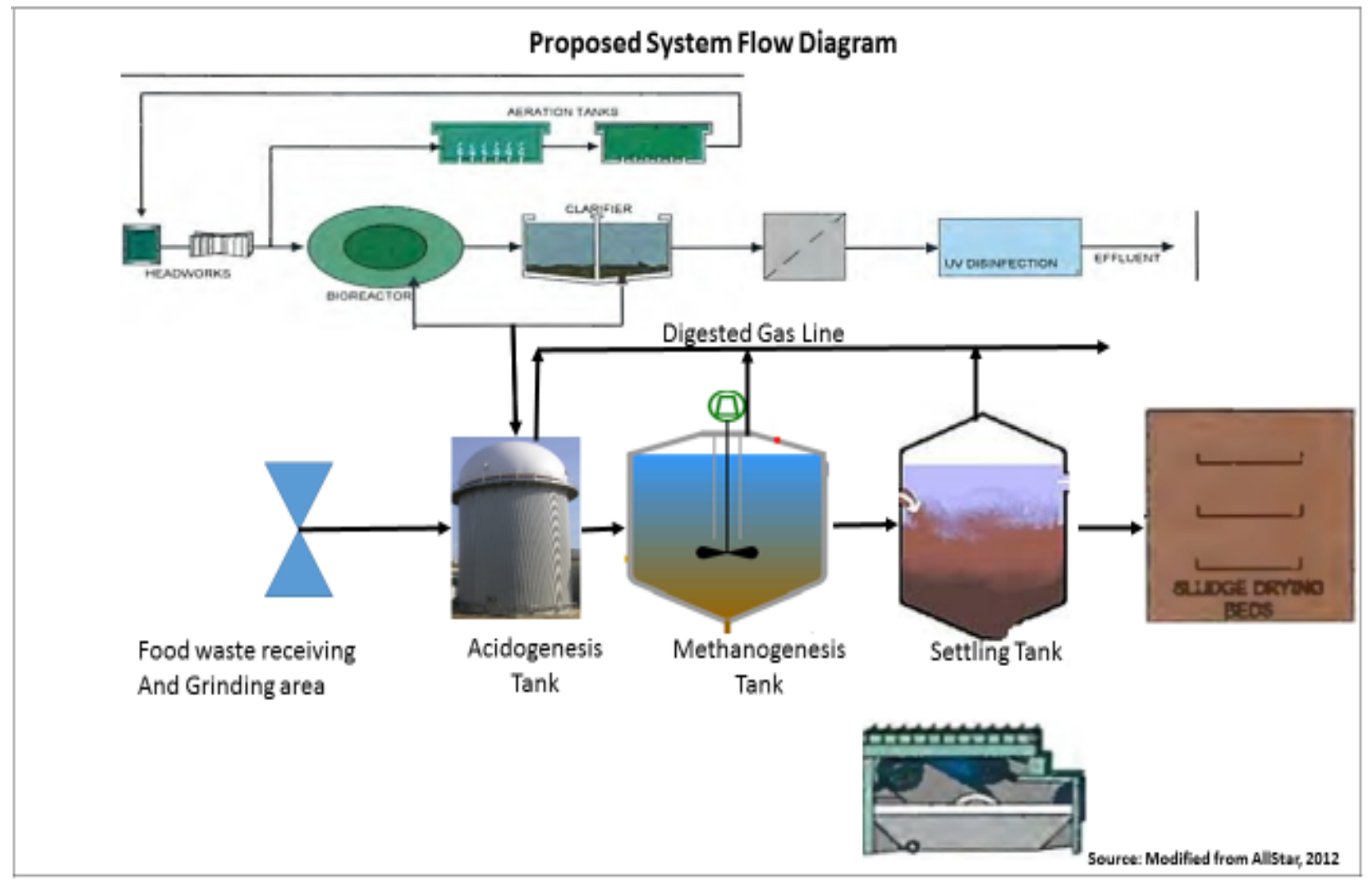

${ }^{5}$ A phone conversation with Tom Dumbaugh, P.E., a Regional Sales Manager for WesTech, IA. 
In addition to all the proposed modifications and additions to the current system mentioned above, the following equipment upgrades will be necessary to make the digesters operational:

- digester control systems,

- heating systems,

- energy take off,

- gas flare, and

- gas generator sets or turbines.

Costs for individual items outlined in Table 5 were collected from openmarket sources as well as from installation staff. However, depending on the specific $\mathrm{AD}$ design, a consultant may be required, as well as additional operation and maintenance (O\&M) costs. Note that for a single-phase system, the first item listed (an additional tank) is not required.

Table 5. Costs estimates for AD system upgrades (ERDC-CERL).

\begin{tabular}{|l|l|r|}
\hline Item & Description & \multicolumn{1}{l|}{ Cost } \\
\hline 1. Tank & 45,000 gallons for acid phase & $\$ 52,000$ \\
\hline $\begin{array}{l}\text { 2. Food Grinder with receiving } \\
\text { hopper }\end{array}$ & A hopper connected with the grinder & $\$ 40,000$ \\
\hline 3. Dual-membrane & Replacing existing dual-membrane & $\$ 106,600$ \\
\hline Total & & $\$ 198,600$ \\
\hline
\end{tabular}




\section{Recommendations for Change}

The collection of food waste, grease, and oil at Fort Huachuca for use at the garrison WWTP will require some changes in protocols for food disposal at the commissaries and DFACs, as summarized in the sections that follow.

\subsection{Collection and transport}

Garrison employees, contractors, and diners in the DFACs and commissaries will be the primary individuals responsible for separating and sorting food from other disposable food service items. To that end, collection containers or totes for food disposal should be placed at each station in the food preparation areas for pre-consumer food waste disposal as well as where diners are emptying food trays in the dining areas for post-consumer food waste. It is recommended that these containers have wheels so they can be wheeled outside to the location designated for food disposal. For efficient transport of food waste to the anaerobic digester, there should be one exterior container for pick up at each DFAC and commissary food waste collection area. Infrastructure should be in place at each container location and collection area to facilitate the quick transfer of food waste from the interior containers into the designated larger food waste exterior containers. The food waste should be picked up once a day or stored in a refrigerator until time of scheduled pickup. If possible, grease and cooking oil should also be hauled directly to the WWTP.

\subsection{Training and signage}

Education is a very critical aspect for the success of the recommendations above. All employees should be trained on new food separation protocols at time of program initiation. New employees should also be trained on food separation methods. Signage explaining food separation rules should be placed in high-traffic areas throughout the kitchen, serving, and dining areas. This signage should also be placed on the walls in the food preparation station as well as on the walls behind the food waste containers and on the containers themselves. All signage about food separation protocols should have pictures with simple illustrations of the separation protocols and the types of food collected as food waste as well as the materials for disposal with municipal solid waste. 


\section{Conclusions}

\subsection{Summary of work}

This project had its genesis at an IMCOM Net Zero training at Fort Huachuca, where the idea was hatched for converting food waste-to-energy at the WWTP. An ERDC-CERL team performed a detailed waste characterization and found that food waste was the highest single constituent of the waste stream. The U.S. EPA joined the team to provide background in current $\mathrm{AD}$ practices across the country and expertise specifically in food waste conversion to energy via $\mathrm{AD}$. The team had a fact-finding visit to Fort Huachuca in December 2015 to learn more about all the conceivable organic wastes that might be fed into the digester. The team investigated two-phase $\mathrm{AD}$ as an option, as this option can improve digester performance in some circumstances. ERDC-CERL team members developed a series of six operational scenarios of varying combinations of food waste and $\mathrm{AD}$ design, based on available feedstocks and the size constraints of existing Fort Huachuca AD tanks. Using these scenarios, the EPA group calculated energy production and net operation costs, and the ERDC-CERL group looked into costs for plant hardware upgrades.

\subsection{Integration of Army Net Zero goals and resiliency}

In support of the Army Net Zero Initiative, co-digestion benefits include greenhouse gas mitigation by diverting food waste from landfills; potential cost savings by reducing energy costs due to production of on-site power; and support of sustainable waste management goals by diverting a high portion of municipal solid waste that would typically have been sent to landfill.

Executive Order 13693, signed by President Obama in March 2015, requires changes in Federal Agency processes and procedures in order to reduce greenhouse gas emissions. This EO promotes the goals set forth for waste reduction in EO 13514 (50\% nonhazardous solid waste and 50\% construction debris), and provides additional goals for compostable material as part of the nonhazardous waste that must be reduced.

For Fort Huachuca specifically, one of the most important reasons for an $\mathrm{AD}$ food waste system is to capture the stored energy content. As energy prices climb and as our nation looks toward methods for renewable energy 
generation and energy independence, capturing energy from food waste is forward-thinking.

As food waste is anaerobically digested, the resulting production of biogas can create enough energy to offset the energy used by the installation. The excess energy could potentially be sold back to the grid. Importantly, the generation of energy on site enhances the resiliency of the installation and can help sustain mission-critical operations in times of energy emergencies, such as black outs.

\subsection{Potential paths forward}

Based on this work, there are two potential paths forward: an optimized two-phase system or a simpler one-phase system. Table 6 summarizes these two paths. The two scenarios were chosen here for study because they will offer the most advantages to Fort Huachuca, given the structural design of its WWTP. An exhaustive sensitivity study would likely illustrate some modest gains, but the scenarios outlined here are reasonable. Of the scenarios shown in Table 6, it is clear that Scenarios 2 and 6 are close in performance, with Scenario 6 being slightly more favorable in terms of cost due to its lower heating requirements and single tank.

However, Scenario 6 has 1\% input WAS vs. 2\% in Scenario 2. If Scenario 6 was rerun with drier WAS, the net benefit would increase and make singlephase $\mathrm{AD}$ a more favorable choice.

Table 6. Summary of findings for two potential paths forward.

\begin{tabular}{|c|c|c|}
\hline & Scenario 2, two-phase AD & Scenario 6, single-phase AD \\
\hline WAS input & $\begin{array}{l}\text { All generated at WWTP, } \\
\text { dried to } 2 \%\end{array}$ & $\begin{array}{l}\text { All generated at WWTP, dried } \\
\text { to } 1 \%\end{array}$ \\
\hline Food input & $\begin{array}{l}\text { All recoverable from DFACs } \\
\text { and other sources }\end{array}$ & $\begin{array}{l}\text { All recoverable from DFACs } \\
\text { and other sources }\end{array}$ \\
\hline Oil and grease & All & All \\
\hline Food grinder & $\sim \$ 10,000$ & $\sim \$ 10,000$ \\
\hline $\begin{array}{l}\text { Replace dual membrane } \\
\text { cover on primary digester }\end{array}$ & $\$ 106,000$ & $\$ 106,000$ \\
\hline $\begin{array}{l}\text { Avoided natural gas cost } \\
\text { (digester heating) }\end{array}$ & $\$ 55,536$ & 56,528 \\
\hline
\end{tabular}




\begin{tabular}{|l|r|r|}
\hline & Scenario 2, two-phase AD & Scenario 6, single-phase AD \\
\hline $\begin{array}{l}\text { Avoided electricity cost } \\
\text { (self-produced power to } \\
\text { run the plant) }\end{array}$ & $\$ 107,851$ & $\$ 107,720$ \\
\hline $\begin{array}{l}\text { Annual net benefit over } \\
\text { current (includes food } \\
\text { mixing input tank) }\end{array}$ & $\begin{array}{r}\$ 172,174 \\
\text { (includes acid tank) }\end{array}$ & $\$ 175,889$ \\
\hline
\end{tabular}

\subsection{Recommendations}

Based on all calculations and modeling, the team recommends restarting the AD system at the WWTP as a one-phase system with the in-feed consisting of WAS dried to $2 \%$, and all recoverable food and FOG. This recommendation is based on the following three factors:

1. The EPA modeling shows that benefits in degradation efficiency, which may arise from two-phase $\mathrm{AD}$, would be overcome in this case by the extra heating required for the additional tank.

2. Single-phase AD will allow the reuse of only the existing tanks, without the cost and disruption of building a third (albeit small) tank.

3. The WWTP was designed for single-phase AD, so it is likely that there would be limited infrastructure upgrades required.

From this study, ERDC-CERL and EPA team members believe that co-digestion of food and biosolids would be a win-win scenario for Fort Huachuca due to eliminating the largest part of the waste stream (food), reducing the cost of biosolids disposal, and generating power for operating the WWTP. 


\section{Appendix A: Background on Anaerobic Digesters}

\section{Anaerobic digestion and co-digestion of food waste}

Introduction

Anaerobic digestion (AD) is a natural biological process where microorganisms convert complex carbohydrates into biogas in an oxygen-free environment. Because $\mathrm{AD}$ is a preferred waste management option over landfilling and incineration, a growing number of communities are using it to further their goals related to sustainable management of organic materials. The $\mathrm{AD}$ process can be an attractive and cost-effective strategy, due in large part to its ability to process a wide range of organic materials for different purposes. For example, communities looking to increase their renewable-energy generation can use $\mathrm{AD}$ continuously, unlike other forms of renewables such as wind or solar. In addition, biogas-a product of the AD process - is a versatile energy resource that can be: burned directly for heat; used as electricity or as combined heat and power; cleaned and compressed for vehicle fuel; or processed for injection directly into a natural gas pipeline system. In general, the use of $\mathrm{AD}$ for waste management will continue to increase as sustainability-driven goals and policies developespecially those related to renewable energy, greenhouse gas mitigation, and waste management.

Figure A1 illustrates the engineered AD process and the potential uses for biogas. Anaerobic bacteria break down complex carbohydrates within the feedstock into organic acids that are then used by methanogenic bacteria to create biogas and slurry. The biogas is removed to produce natural gas, electricity, heat, or vehicle fuel. 
Figure A1. Anaerobic digester system components (U.S. EPA ORD).

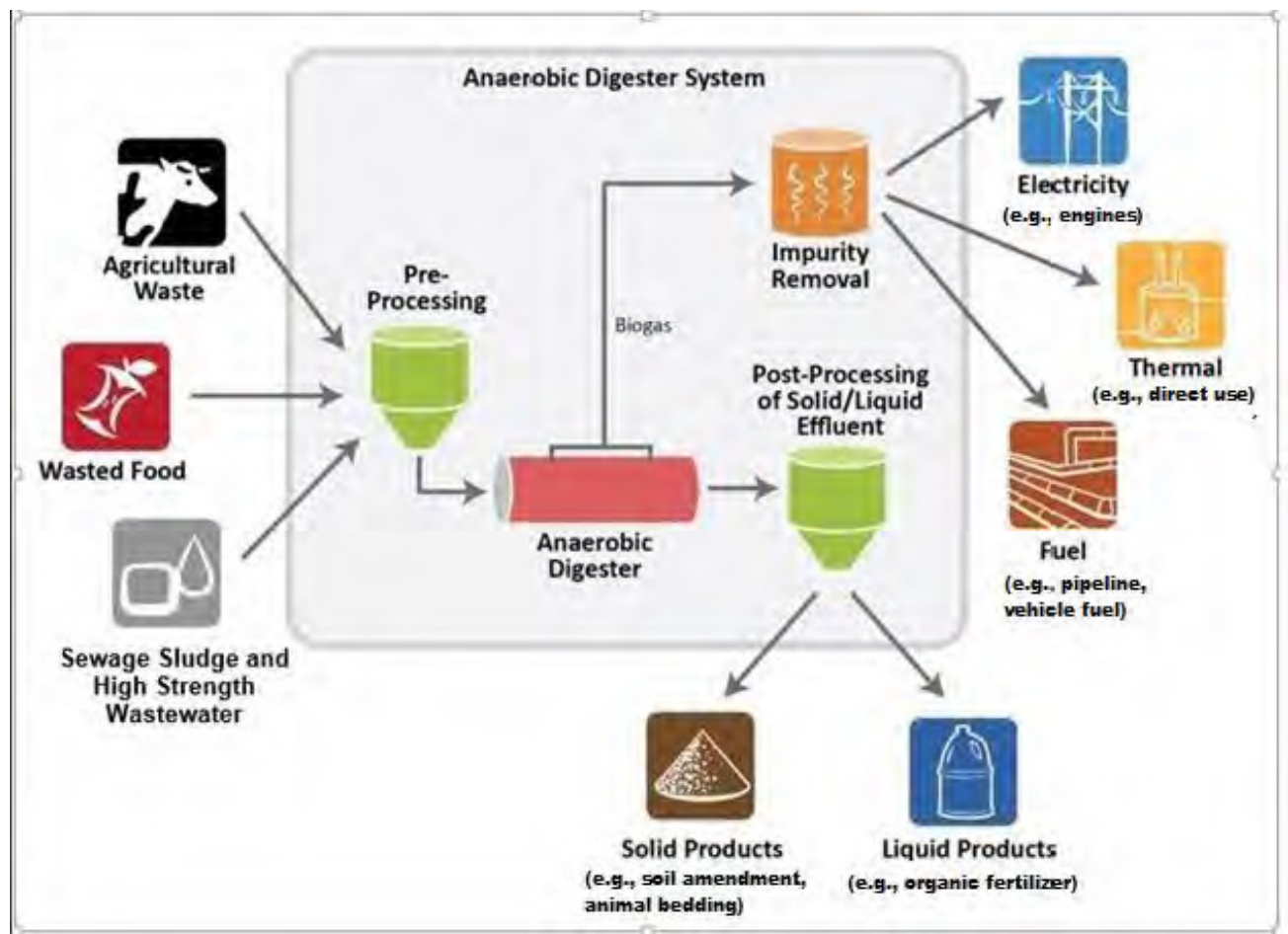

\section{Anaerobic digestion systems in the United States}

Early anaerobic digesters were predominantly found in the agriculture sector during the energy crisis at the beginning of the 1970s, however, the majority of these early digesters failed. Factors contributing towards this failure can be attributed to technological shortfalls: poor design, poor equipment selection, and lack of maintenance. For agricultural applications in general, anaerobic digesters are complex systems and require experience to optimize power generation. While the current technology and operational capacities have improved, agricultural digesters are typically small and rely on simple technology. Factors such as animal type, population size, and manure collection systems are the primary considerations when determining a potential farm-based digester. The use of $\mathrm{AD}$ for livestock waste management is tracked by the AgSTAR program, ${ }^{6}$ a partnership of the U.S. Environmental Protection Agency (U.S. EPA), the U.S. Department of Agriculture (USDA), and the U.S. Department of Energy (DOE) (U.S. EPA 2015).

\footnotetext{
6 https://www.epa.gov/agstar
} 
In the United States, the majority of anaerobic digesters are used at wastewater treatment plants (WWTPs). Municipal wastewater sewage contains a high fraction of organic biomass solids and many wastewater treatment plants use anaerobic digestion to reduce the volume of these solids while reducing pathogens in the process. In 2008, the U.S. EPA Clean Watershed Needs Survey identified 3,171 wastewater treatment facilities in the United States. Of these, 1,351 now use $\mathrm{AD}$ for treatment of municipal wastewater (U.S. EPA 2015, 12).

In a municipal WWTP setting, anaerobic digesters are used as a complementary process to other forms of treatment (e.g., aerobic processes). Digesters are effective for treating waste from aerobic processes and other "high-strength" wastes flowing into the facility-namely fats, oils, and greases or other organic feedstocks that have a high biological oxygen demand (BOD). High BOD wastes contain relatively high amounts of decomposable organic matter that can, under anaerobic conditions, produce biogas. Biogas is an extremely versatile energy resource that can be used to offset energy costs at WWTPs. Plants that do not use anaerobic digesters typically produce more biosolids that necessitate alternative disposal methods such as land application, incineration, or landfilling. Treating high-strength wastewater with anaerobic digesters is gaining traction, especially in circumstances where stringent waste and water quality regulations may restrict opportunities for land application, thus forcing municipal WWTPs to look into other pretreatment options. With the exception of digestate made using sewage sludge, there are currently no national standards for the classification of digestate products. Code of Federal Regulations 40 CFR Part 503 governs the standards for final use and disposal of sewage sludge and derived products.

\section{Food waste co-digestion at WWTPs and biogas production}

The biogas produced from anaerobic digestion can be harnessed as an energy resource to replace fossil fuels, create electricity, or create heat. Despite the renewable potential and other environmental benefits, only a little over 100 of the anaerobic digesters at treatment plants use the biogas produced as an energy resource. Instead, the vast majority of the WWTPs flare-off the biogas or only use it to heat the operations of the anaerobic digester itself.

Co-digestion by adding food waste to wastewater anaerobic digesters can substantially increase methane and biogas generation potential. According 
to AgSTAR, food waste generates about 210 cubic meters of biogas per ton, depending on its characteristics. 7 The biogas produced from a properly functioning digester is typically 55\%-70\% methane and $25 \%-30 \%$ carbon dioxide, with the remaining fraction comprised of water vapor, nitrogen, hydrogen, and hydrogen sulfide (Chapman and Muller 2010). Since the relative percentage of methane determines the BTU in the biogas, a cubic meter of biogas at $65 \%$ methane will yield approximately 23,242 BTU of useable energy. Therefore, each ton of food waste could generate about $220 \mathrm{kWh}$ of electricity.

\section{Parameters affecting co-digestion}

The most important parameters affecting co-digestion of food waste are:

- $\mathrm{pH}$ value of the reacting material which can inhibit or enhance the activity of methanogenic bacteria;

- composition of the food waste in order to predict the methanogenesis potential and thus efficient AD design;

- organic loading rate, as it determines the amount of volatile solids that can be used as an input in the $\mathrm{AD}$ system;

- retention time in $\mathrm{AD}$ reactors as optimal retention time ensures more complete degradation of the substrate, thus impacting the cost-effectiveness of operations; and

- operating temperature, as finding the optimal temperatures will ensure the proper functioning and survival of bacteria.

Numerous studies have investigated the relationship among these factors with regard to biogas generation and are described elsewhere (Bond et al. 2012; L. Arsova, 2010).

\footnotetext{
7 https://www.epa.gov/agstar/agstar-data-and-trends
} 


\section{Appendix B: Example Anaerobic Digester Systems}

Reviewing examples of WWTPs will show different types of AD systems and how they integrate food into their digester operations. Operational parameters and procedures at other sites can be treated as lessons-learned for planning a system at Fort Huachuca.

Each of the examples shown in Appendix B can be used to approximate expected biogas generation per unit of plant inflow. These examples include an $\mathrm{AD}$ system in a campus environment, quite similar to a military installation in terms of the dining halls and shows a new type of $\mathrm{AD}$ process, two-phase, incorporated at a plant similar to WWTP2.

The specifics of the $\mathrm{AD}$ process is described in detail in Appendix A. For now, a distinction will be made only between single- and two-phase AD systems. Single-stage is the most common (almost universal) process, wherein all of the microbial and chemical AD processes occur in a single tank. This system has the advantage of relatively simple construction and operation. The drawback is somewhat longer biosolids residence time to achieve methane conversion. By contrast, two-phase AD attempts to separate and optimize two sets of $\mathrm{AD}$ subprocesses in separate tanks. The advantage is quicker, more complete organics conversion to biogas; however, this system requires more infrastructure and control systems.

\section{Co-digestion of food and biosolids}

WWTPs with anaerobic digesters that have excess capacity can accept food waste feedstocks with potentially little incremental cost. By installing generators, the biogas-enhanced by the addition of food waste-may be able to generate enough electricity to power the facility and generate additional revenue by selling excess power back to commercial utilities. While comparisons between different $\mathrm{AD}$ systems that use co-digestion are complicated due to varying local conditions, some illustrative examples are highlighted in EPA's 2014 report on six wastewater treatment facilities using co-digestion (U.S. EPA 2014), and four of these are summarized below:

- The Central Marin Sanitation Agency (CMSA) is located in San Rafael, California. CMSA is a regional wastewater agency serving about 120,000 customers. Up to six billion gallons of wastewater per year are 
treated and released. The CMSA treats an average dry weather flow (ADWF) of seven million gallons per day (MGD) with the capacity to treat 125 MGD. The WWTP has two anaerobic digesters, with a combined capacity of approximately two million gallons (MG). The facility started their co-digestion program in 2013 with FOG and began receiving food waste in late January 2014. Before co-digestion, CMSA produced enough biogas to provide approximately eight hours of power. With co-digestion, CMSA is hoping to meet all the plant's power needs with the biogas produced on site.

- The East Bay Municipal Utility District (EBMUD) serves approximately 650,000 people in an 88-square-mile area along the east shore of the San Francisco Bay, treating wastewater from Alameda, Albany, Berkeley, El Cerrito, Emeryville, Kensington, Oakland, Piedmont, and a part of Richmond. The facility treats an ADWF of 6o MGD, with the capacity to treat $168 \mathrm{MGD}$. It has 11 anaerobic digesters with the combined capacity of approximately 22 MG. EBMUD began co-digesting in 2002 and, in 2012, EBMUD became the first WWTP in North America to produce more renewable energy on site than is needed to run the facility.

- The Hill Canyon Wastewater Treatment Plant (HCTP) provides wastewater treatment for $90 \%$ of the 128,000 residents of Thousand Oaks in California. HCTP currently treats an ADWF of 9.5 MGD and has the capacity to treat 14 MGD. The digester design capacity is 2.8 MG. Biogas produced from digested solids and food waste fuels a $295 \mathrm{~kW}$ and a $630 \mathrm{~kW}$ engine. HCTP will soon become energy positive.

- The Sheboygan Regional Wastewater Treatment Facility in Wisconsin serves the city of Sheboygan, Sheboygan Falls, Village of Kohler, the Town of Lima, the Town of Sheboygan, and the Town of Wilson. The WWTP treats an ADWF of 18.4 MGD and has the capacity to treat 56.8 MGD. The WWTP has three anaerobic digesters, with a total capacity of 4.8 MG. The resulting biogas fuels ten $30 \mathrm{~kW}$ and two $200 \mathrm{~kW}$ microturbines, producing 2,300 megawatt hours of electricity annually. This production is used to meet $90 \%$ of the facility's annual electrical needs and $85 \%$ of its annual heating requirements.

\section{Co-digestion with food from dining halls}

West Lafayette, Indiana, has a population of about 30,000, and a combined sewer system that generates about 8 MGD of influent to its WWTP. West Lafayette is also the home of Purdue University. The city and university arrived at a mutually beneficial arrangement whereby the university 
sends all food waste from its dining halls to the WWTP for incorporation into the city's AD system. This arrangement allows more biogas to be produced for energy conversion.

At about two percent solids, the wasted sludge from the wet side of the plant is sent to two, parallel, mesophilic, 500,000 gallon $\mathrm{AD}$ tanks. This is a single-phase system. Approximately 2,500 pounds of food waste is delivered from the university's recycling program per day. Trucks deliver the food in rolling carts to a custom-built receiving station, which is adjacent to the pump building. There, the carts are emptied mechanically into a grinder (see Figure B1). ${ }^{8}$ On alternating days, the food and grease are mixed with the digester sludge and then pumped into one of the digesters. The digester retention time is about 25 days. This collection system could serve as a model for a military installation.

Siloxanes and moisture are removed from the biogas and then fed into the Capstone microturbines, producing approximately $130 \mathrm{~kW}$ of electrical power to help run the WWTP plant.

Figure B1. Food-waste receiving station at West Lafayette, IN (ERDC-CERL).

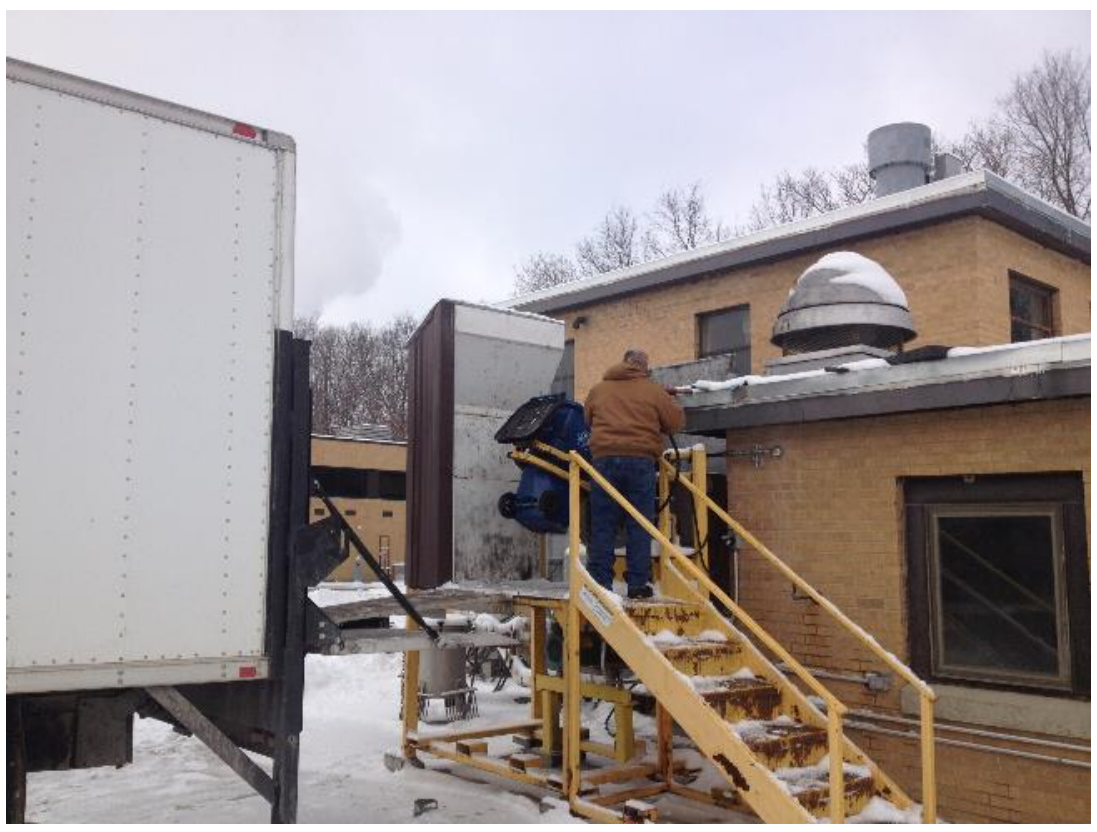

8 West Lafayette uses a "Muffin Monster" model by JWC Environmental, headquartered in Santa Ana, California (www.jwce.com). 


\section{Two-phase AD}

After severe foaming issues that affected operations, personnel at the Woodridge-Greene Valley Wastewater Treatment Plant (DuPage Co., IL) converted the plant's high-rate (single-phase) digestion system to a twophase $\mathrm{AD}$ system, which enabled the concentrated waste-activated sludge (WAS) to be treated at high loading rates with low hydraulic retention times. This approach alleviated severe foaming issues, as the polymeric foaming agents were destroyed in the acid-digester environment. A pilot study was conducted before full scale implementation at Woodridge, IL. The Woodridge plant is designed for a total input of 12 MGD. Table B1 gives parameters for this AD system. The average sludge inflow to this system is 40,000 gallons per day. Should the Directorate of Public Works (DPW) at Fort Huachuca wish to explore a two-phase system, these parameters can serve as rules of thumb for design and operation.

In this approach, the operation of the acid-phase tank is ultimately controlled by the hydraulic retention time (HRT). In turn, the maximum HRT is limited by tank size. However, if the height of the tank discharge is changed, the tank volume is effectively changed. At the Woodridge facility, the acid tank has three discharge ports, which can yield a tank volume of $76,000,64,000$, or 47,000 gallons (Figures B2 and B3). Because the sludge inflow varies with overall plant loading, operators can change the outflow port on the acid tank, such that the HRT remains close to 1.5 days. This selecting of outflow ports which can change residence time and affect $\mathrm{pH}$ and methane production, is the chief adjustment that operators can make.

The methane tank is operated at thermophilic temperatures in an effort to reduce pathogens and to achieve a Class A compost for land application.

The parameters and values shown in Table B1 and Table B2 are monitored closely, as changes in these parameters can affect treatment drastically. For example, if the $\mathrm{pH}$ in the acid tank starts to increase, the HRT becomes longer, promoting the growth of methanogens and their domination over the acidogens. Similarly, increases in the methane content of the biogas from the acid tank can also result in a longer HRT. On the other hand, if the $\mathrm{pH}$ in the acid tank does not decrease in response to the inflow value, then the HRT is likely too short. The parameters in these tables (e.g., HRT and $\mathrm{pH}$ ) can serve as operational rules of thumb from a successful implementation of a two-phase system. 
Table B1. Operational parameters of the anaerobic digestion system at the Greene Valley WWTP (ERDC-CERL with data provided by the DuPage County (IL) Public Works engineer).

\begin{tabular}{|c|c|c|c|}
\hline Operating Parameter & Acid Tank & Methane Tank & Rest Tank \\
\hline Operating volume (gal) & 50,000 & 550,000 & 500,000 \\
\hline $\begin{array}{l}\text { Daily sludge inflow } \\
\text { (gal) }\end{array}$ & 40,000 & 40,000 & 40,000 \\
\hline HRT (days) & 1.3 & 13.8 & 12.5 \\
\hline $\mathrm{pH}$ influent & 6.6 & 5.8 & 8.1 \\
\hline pH effluent & 5.8 & 8.1 & unknown \\
\hline Operating temp & $\begin{array}{l}90-100^{\circ} \mathrm{F} \\
\text { mesophilic }\end{array}$ & $\begin{array}{l}130^{\circ} \mathrm{F} \\
\text { thermophilic }\end{array}$ & unheated \\
\hline Total solids in & $6 \%$ & $5.3 \%$ & $4.2 \%$ \\
\hline Total solids out & $5.3 \%$ & $4.2 \%$ & $3.8 \%$ \\
\hline Volatile solids influent & $80 \%$ & $72 \%$ & $64 \%$ \\
\hline Volatile solids effluent & $72 \%$ & $64 \%$ & $62 \%$ \\
\hline Mixing & $\begin{array}{l}\text { external pumps, } \\
200 \text { gpm }\end{array}$ & $\begin{array}{l}\text { JDV Turbomixer } \\
\text { "bubble cannon" } \\
200 \text { CFM }\end{array}$ & none \\
\hline
\end{tabular}

Table B2. Biogas composition from anaerobic digesters at the Greene Valley facility (ERDC-CERL with data provided by the DuPage County (IL) Public Works engineer).

\begin{tabular}{|l|l|l|l|}
\hline Phase & Methane & Carbon Dioxide & Biogas volume (kft $3 /$ day) \\
\hline Acid phase & $30 \%$ & $60 \%$ & 7 \\
\hline Methane phase & $60 \%$ & $30 \%$ & 100 \\
\hline
\end{tabular}


Figure B2. Elevation drawing of acid-phase tank at Greene Valley Facility (DuPage County (IL) Public Works).

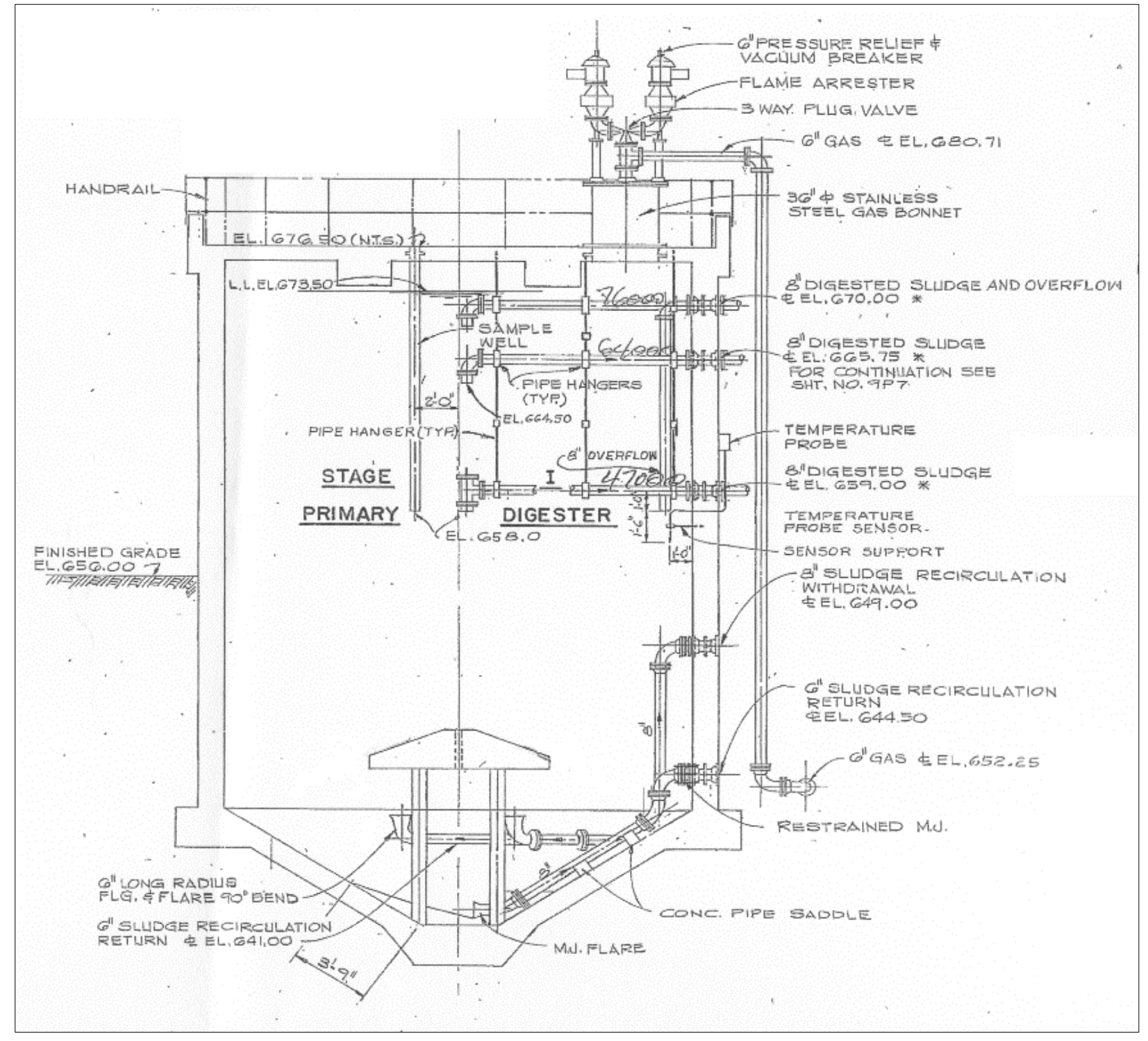


Figure B3. Three discharge pipes on the side of the acid phase tank at Green Valley facility (ERDC-CERL).

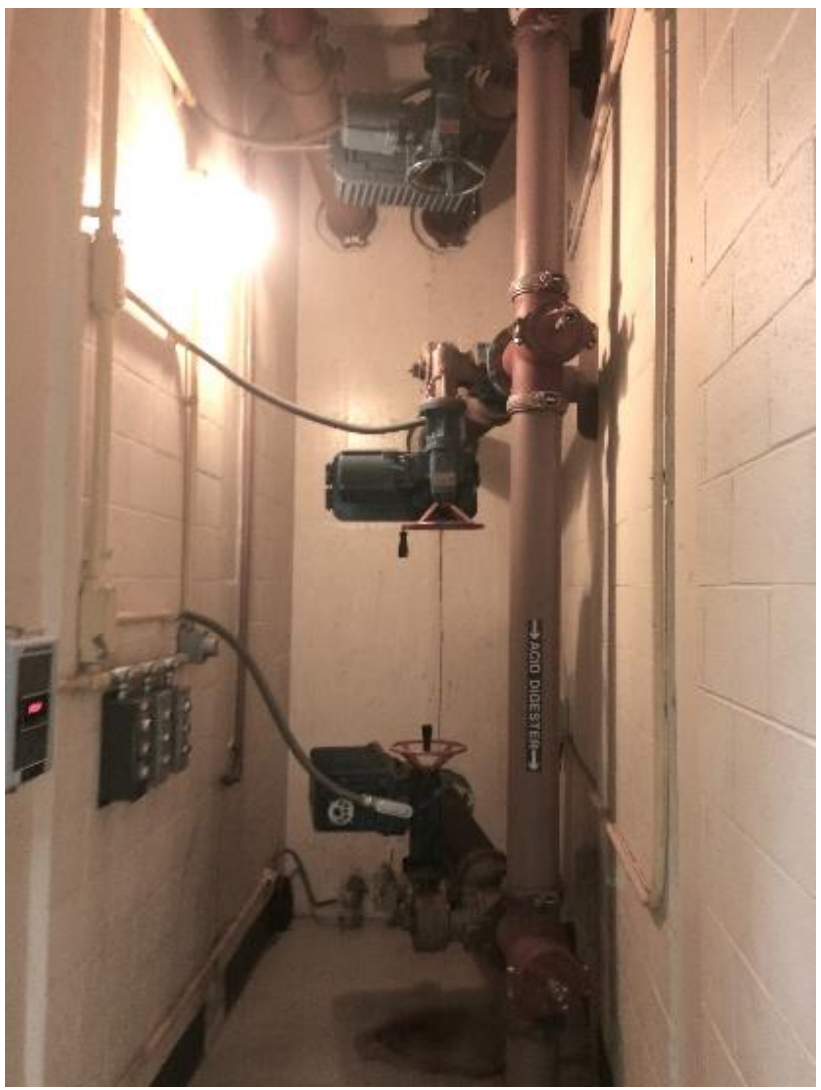




\section{Appendix C: Summary of Biological Process of Anaerobic Digestion}

\section{Technical overview of the biological process of anaerobic digestion}

Effective $\mathrm{AD}$ relies on the degradation of organic material via the metabolic actions of microorganisms and ultimately results in the formation of biogas. The degradation of organics (carbohydrates, oils, fats and proteins) in the anaerobic digestion process can be divided into four phases: hydrolysis, acidogenesis, acetogenesis, and methanogenesis (Figure C1). These phases comprise several successive stages of chemical and biological reactions involving a consortium of microbes and extracellular and intracellular enzymes.

Figure C1. Simplified diagram of anaerobic digestion phases (ERDC-CERL).

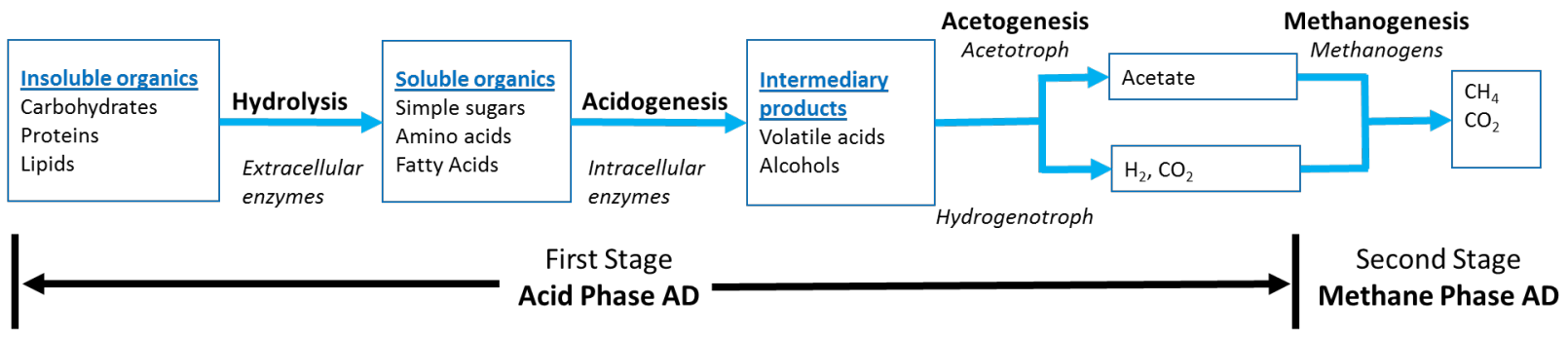

\section{Phases of anaerobic digestion}

First phase - hydrolysis

A substantial portion of the organic matter present in food waste is composed of large, complex polymer chains (carbohydrates, proteins, and lipids). These polymers are far too large to be directly used by microorganisms as a source of energy and must first be broken down into more soluble materials. To facilitate in the breakdown process, microbes secrete hydrolytic enzymes to transform insoluble organics into soluble monomers ${ }^{9}$ and simple polymers (sugars, amino acids, and fatty acids). The conversion of insoluble matter into soluble materials occurs at different rates and is dependent on the complexity of the starting material. Simple polymers are converted into smaller units in a matter of hours, while 
the hydrolysis of more complex molecules like lipids and proteins can take a few days.

\section{Second phase - acidogenesis}

In the second phase, acidogenic bacteria transform the hydrolysis products into volatile fatty acids (VFAs). The products-hydrogen, carbon dioxide and acetic acid-that can be utilized directly by methanogenic bacteria will skip the third stage listed below.

Figure $\mathrm{C} 2$ shows a detailed schematic representation of the four key biological and chemical stages in AD: (1) hydrolysis: complex organic molecules are decomposed into simple organic molecules; (2) acidogenesis: the decomposition of simple molecules into volatile fatty acids; (3) acetogenesis: the simple molecules are further digested mainly into acetic acids as well as carbon dioxide and hydrogen; and (4) methanogenesis: in the final stage of anaerobic digestion, the intermediate products generated in the preceding stages are converted into methane, carbon dioxide and water.

Generally, most acidogens are relatively fast growing microorganisms and thus if left unchecked, will accelerate growth which can cause acidification to the reactor. Acidic conditions are toxic to methanogens and can inhibit methanogenesis resulting in operational failure of the anaerobic reactor. 
Figure C2. Detailed schematic of the four key AD phases (ERDC-CERL).

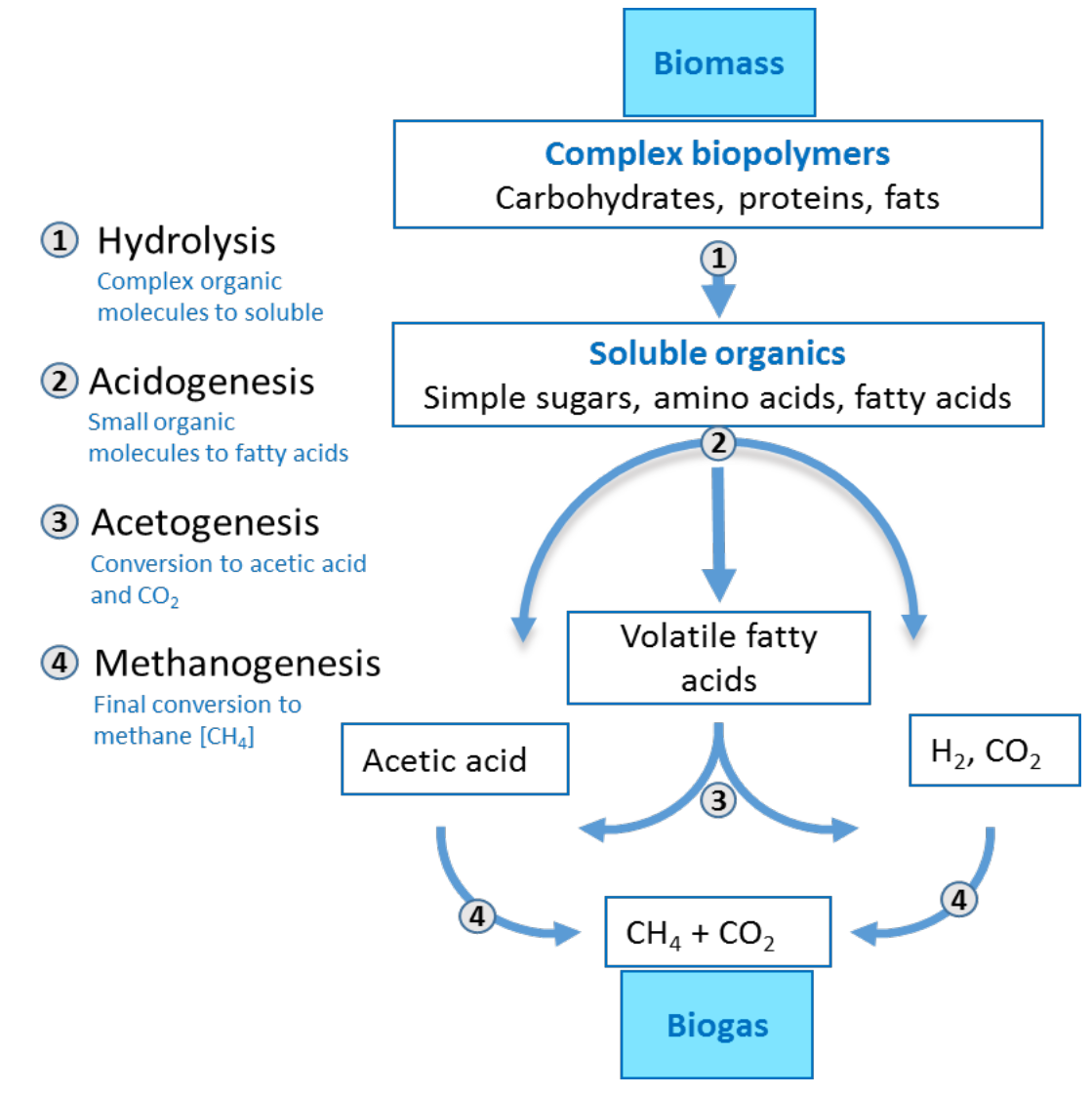

\section{Third phase - acetogenesis}

During the acetogenesis phase, the products of the second phase are converted into the final precursors (hydrogen, carbon dioxide and acidic acid) for methane generation by acetogenic bacteria. Several rate limiting steps associated with this phase include the potential competition between acetogens and sulfate reducing bacteria for hydrogen and poor production of acetate due to low populations of acetogens.

\section{Fourth phase - methanogenesis}

Methanogenesis is the last phase of the anaerobic digestion process. During this final phase, methane is produced by a group of bacteria known as methanogens which produce methane via two different pathways. The major route generates methane and carbon dioxide and is carried out by acetoclastic methanogens. The secondary route is carried out by hydrogenophic methanogens. Due to the slow growth rates of methanogens, which makes them prone to washing out of the system, this last phase can be rate limiting. The efficiency of methane production is also negatively affected 
by the accumulation of toxic compounds such as ammonia and/or hydrogen sulfide. Finally, as discussed above, the consortia of methanogens may not be able to keep pace with the production of VFAs, and acidification can inhibit methanogenesis and result in reactor failure. Table $\mathrm{C} 1$ summarizes the phases of $\mathrm{AD}$ and the potential limitations associated with each phase.

Table C1. Summary of phases of anaerobic digestion (ERDC-CERL).

\begin{tabular}{|l|l|l|l|l|}
\hline Phase & Description & Microorganisms & Potential Limitations & Two-phase classification \\
\hline Hydrolysis & $\begin{array}{l}\text { Particulate organic } \\
\text { material hydrolyzed to } \\
\text { soluble units }\end{array}$ & Hydrolytic bacteria & Hydrolysis of lignocellulose & Acid-phase \\
\hline Acidogenesis & $\begin{array}{l}\text { Soluble units converted } \\
\text { to VFAs, alcohols, } \mathrm{H}_{2} \\
\text { and } \mathrm{CO}_{2}\end{array}$ & Acidogenic bacteria & Acid accumulation & Methane-phase \\
\hline Acetogenesis & $\begin{array}{l}\text { Conversion of fatty } \\
\text { acids and } \mathrm{H}_{2} \text { and } \mathrm{CO}_{2}\end{array}$ & Acetogenic bacteria & $\begin{array}{l}\text { Competition with sulfate } \\
\text { producers, low production } \\
\text { of acetate }\end{array}$ & \\
\hline $\begin{array}{l}\text { Methanogene } \\
\text { sis }\end{array}$ & $\begin{array}{l}\text { Conversion of acetate } \\
\text { and } \mathrm{H}_{2} \text { and } \mathrm{CO}_{2} \text { to } \\
\text { methane }\end{array}$ & Methanogenic bacteria & $\begin{array}{l}\text { Slow growth, wash-out, } \\
\text { inhibition due to toxic build- } \\
\text { up }\end{array}$ & \\
\hline
\end{tabular}

\section{Two phase AD}

In conventional $\mathrm{AD}$ systems, the acid and methane forming microorganisms co-exist in the same environment. In such a system, the VFA production rate exceeds the conversion rates of VFA's to methane. This can result in acid accumulation, leading to a $\mathrm{pH}$ drop and consequently inhibition of methanogenesis. To circumvent this issue, two phase AD can be implemented such that the two major microbial phases are carried out in two separate reactors (acidogenesis and methanogenesis) (see Figure $\mathrm{C}_{3}$ ). The first reactor (acid phase reactor) isolates phases 1-3 (hydrolysis, acidogenesis and acetogenesis) into a single reactor and is designed for a retention time of 1-2 days. It can be operated under mesophilic or thermophilic conditions. The $\mathrm{pH}$ of the reactor is maintained between 5.5 and 6.5 and there is minimal methane production in this reactor. The second reactor is dedicated to methane generation and designed for a retention time of 10 days under a mesophilic temperature regime.

Phase separation has several major advantages, as it (1) isolates and optimizes potentially rate-limiting steps; (2) controls $\mathrm{pH}$, thereby improving 
reaction kinetics; and (3) eliminates potential toxic build-up (Ma et al 2016). Based on data from two full-scale facilities (Ghosh et al. 1995) twophase $\mathrm{AD}$ has shown that more effective sludge digestion is achieved through the optimization of operating conditions for each phase (Figure C3).

Figure C3. Diagram of a two-phase AD system (adapted from Figure 5.8 in Turovskiy and Mathai 2006).

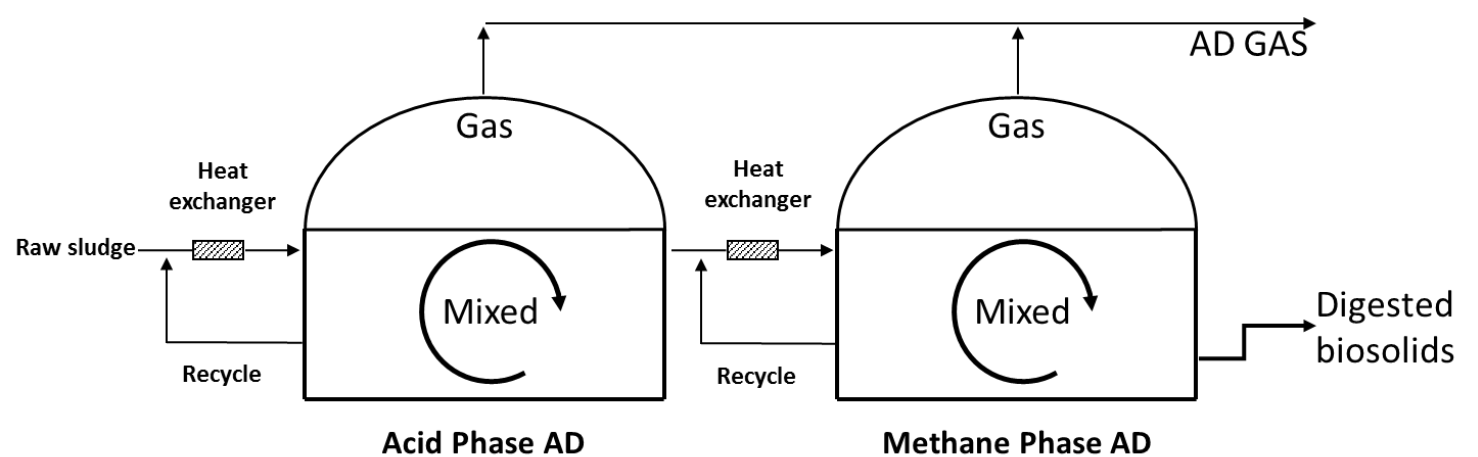




\section{Appendix D: Co-Digestion Economic Analysis Tool (Co-EAT) Scenario Simulations}

The following scenarios were simulated by the U.S. EPA for Fort Huachuca, using Co-EAT V7.1, with variables and data as shown. All scenarios use no $\mathrm{AD}$ except Scenario 6. Input variables are given according to the graphical user interface (GUI) of Co-EAT. Appendix E shows the mathematical equations behind each scenario. 


\section{Scenario 1}

The Scenario 1 simulation was conducted on 29 November 2016, with no $\mathrm{AD}$. Scenario 1 variables are given below and on the pages that follow.

\section{GUI Input Variables}

\section{Digester}

\begin{tabular}{|c|c|c|}
\hline \multirow[t]{3}{*}{ Dimensions: } & $\mathrm{n} / \mathrm{a}$ & $-\mathrm{ft}$ \\
\hline & $\mathrm{n} / \mathrm{a}$ & $-\mathrm{ft}$ \\
\hline & $\mathrm{n} / \mathrm{a}$ & \# of Digesters \\
\hline Effective Operating Capacity : & $0.00 \%$ & \\
\hline Buffer Capacity : & $0.00 \%$ & \\
\hline Total Digester Volume : & 0 & _gal \\
\hline Annual Operational and Maintenance Cost & So & \\
\hline \multirow[t]{2}{*}{ Biogas Production Rate } & 15 & $\mathrm{ft}^{\wedge} 3$ (biogas)/lb(vs destroyed) \\
\hline & Current & Future \\
\hline \multicolumn{2}{|l|}{ Percent Volatile Solids Reduction: } & $60 \%$ \\
\hline
\end{tabular}

Feedstocks

\begin{tabular}{|c|c|c|c|c|c|c|}
\hline Feedstock & $\begin{array}{c}\text { Time of } \\
\text { Use }\end{array}$ & Quantity & $\begin{array}{c}\text { Units } \\
\text { per Day }\end{array}$ & $\begin{array}{l}\text { Specific } \\
\text { Gravity }\end{array}$ & $\begin{array}{c}\text { Total Solids } \\
(\%)\end{array}$ & $\begin{array}{l}\text { VS/TS } \\
\text { Ratio }\end{array}$ \\
\hline Waste Activated Sludge (WAS) & Both & 30000 & Gal. & 1 & 0.5 & 0.75 \\
\hline Brown Grease & Future & 548 & Gal. & 1 & 29.9 & 0.96 \\
\hline Cooking Oil & Future & 400 & Gal. & 1 & 90 & 0.96 \\
\hline DFAC Food & Future & 400 & Gal. & 1 & 30 & 0.85 \\
\hline Other Food & Future & 450 & Gal. & 1 & 30 & 0.85 \\
\hline Horse Manure & Future & 300 & Gal. & 1 & 40 & 0.8 \\
\hline
\end{tabular}

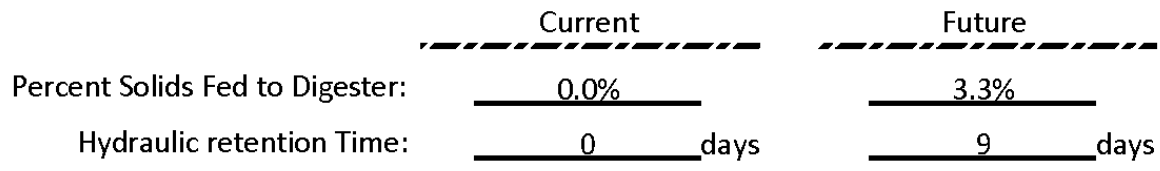


Economics

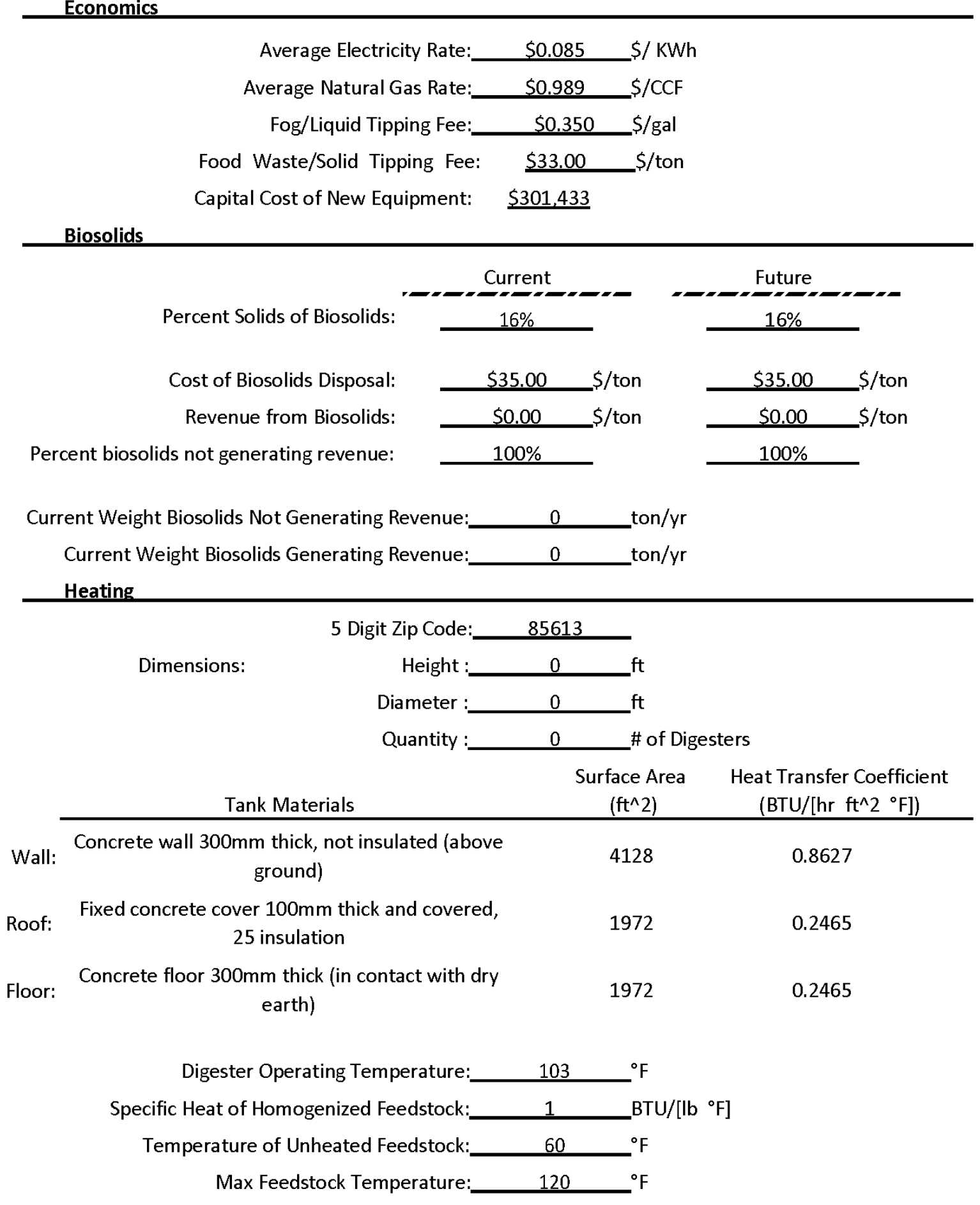




\section{Biogas Use Variables}

\section{Economics}

$\begin{array}{rr}\text { Discount Rate: } & 4 \% \\ \text { Analysis Period: } & 15 \\ \text { Engineering \& Installation Factor: } \quad 15.00 \%\end{array}$

Future Biogas Use Scenario Variables

Future A

Heat Recovery Efficiency: $\quad 75 \%$

Future B

Low Heating Value of Methane:
Btu Conversion Factor: ${ }^{B t u / c f}$

Annual Operations and Maintenance Costs: $\$ 0$

Future C

\begin{tabular}{rlr} 
Methane Content of Biogas: & $60 \%$ & Low \\
Heating Value of Methane: & 1011 & Btu/cf \\
Energy Content of Methane: & 20160 & BTU/lb \\
GGE conversion factor: & 5.66 & lb/GGE \\
Gas Purification Efficiency: & $98 \%$ \\
\cline { 2 - 2 } & $\$ 2.08$ \\
\hline
\end{tabular}

Cost assumption of CNG fueling station + truck

upgrades: $\$ 400,000$

Capital cost of gas upgrading system: $\$ 150.000$

Annual Operations and Maintenance Costs: \$0 


\section{Scenario 2}

The Scenario 2 simulation was conducted on 29 November 2016, with no $\mathrm{AD}$. Scenario 2 variables are given below and on the pages that follow.

\section{GUI Input Variables}

\section{Digester}

Dimensions:

Max Liquid Height : $\mathrm{n} / \mathrm{a}$

Diameter : $\mathrm{n} / \mathrm{a}$

Quantity :__n/a___ \# of Digesters

Effective Operating Capacity : $\quad 0.00 \%$

Buffer Capacity : $\quad 0.00 \%$

Total Digester Volume : $\quad 0 \quad$ gal

Annual Operational and Maintenance Cost:

\$0

Biogas Production Rate:

$15 \_\mathrm{ft}^{\wedge} 3$ (biogas)/lb(vs destroyed)

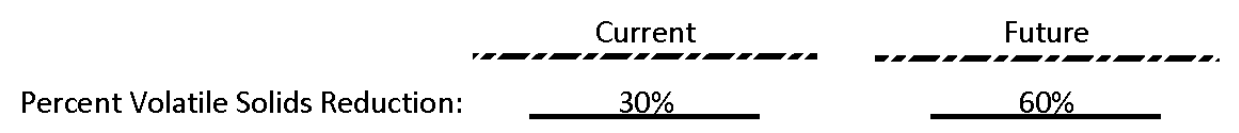

Feedstocks

\begin{tabular}{llcccccc} 
& & Time of & & Units & Specific & Total Solids & VS/TS \\
Use & Quantity & per Day & Gravity & (\%) & Ratio \\
\cline { 2 - 8 } \#1 & Waste Activated Sludge (WAS) & Both & 7650 & Gal. & 1 & 2 & 0.75 \\
$\# 2$ & Brown Grease & Future & 548 & Gal. & 1 & 29.9 & 0.96 \\
$\# 3$ & Cooking Oil & Future & 400 & Gal. & 1 & 90 & 0.96 \\
$\# 4$ & DFAC Food & Future & 400 & Gal. & 1 & 30 & 0.85 \\
$\# 5$ & Other Food & Future & 450 & Gal. & 1 & 30 & 0.85 \\
$\# 6$ & Horse Manure & Future & 300 & Gal. & 1 & 40 & 0.8
\end{tabular}

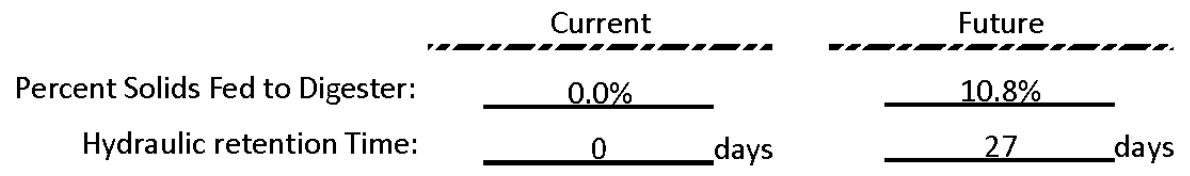


Economics

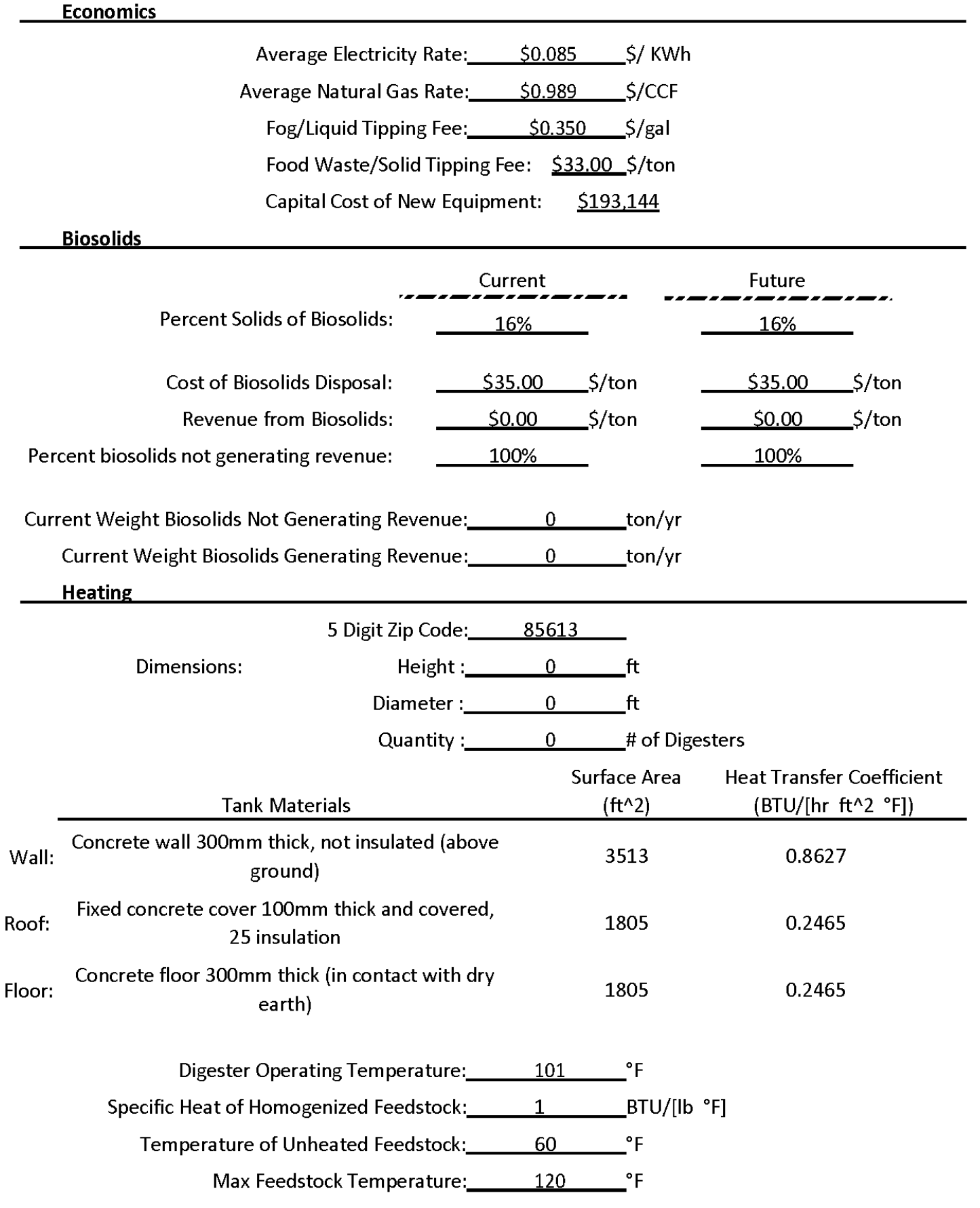




\section{Biogas Use Variables}

Economics

Discount Rate: $\frac{4 \%}{40}$
Analysis Period: $\frac{15}{15.00 \%}$

Future Biogas Use Scenario Variables

Future $A$

Heat Recovery Efficiency: $\quad 75 \%$

Future B

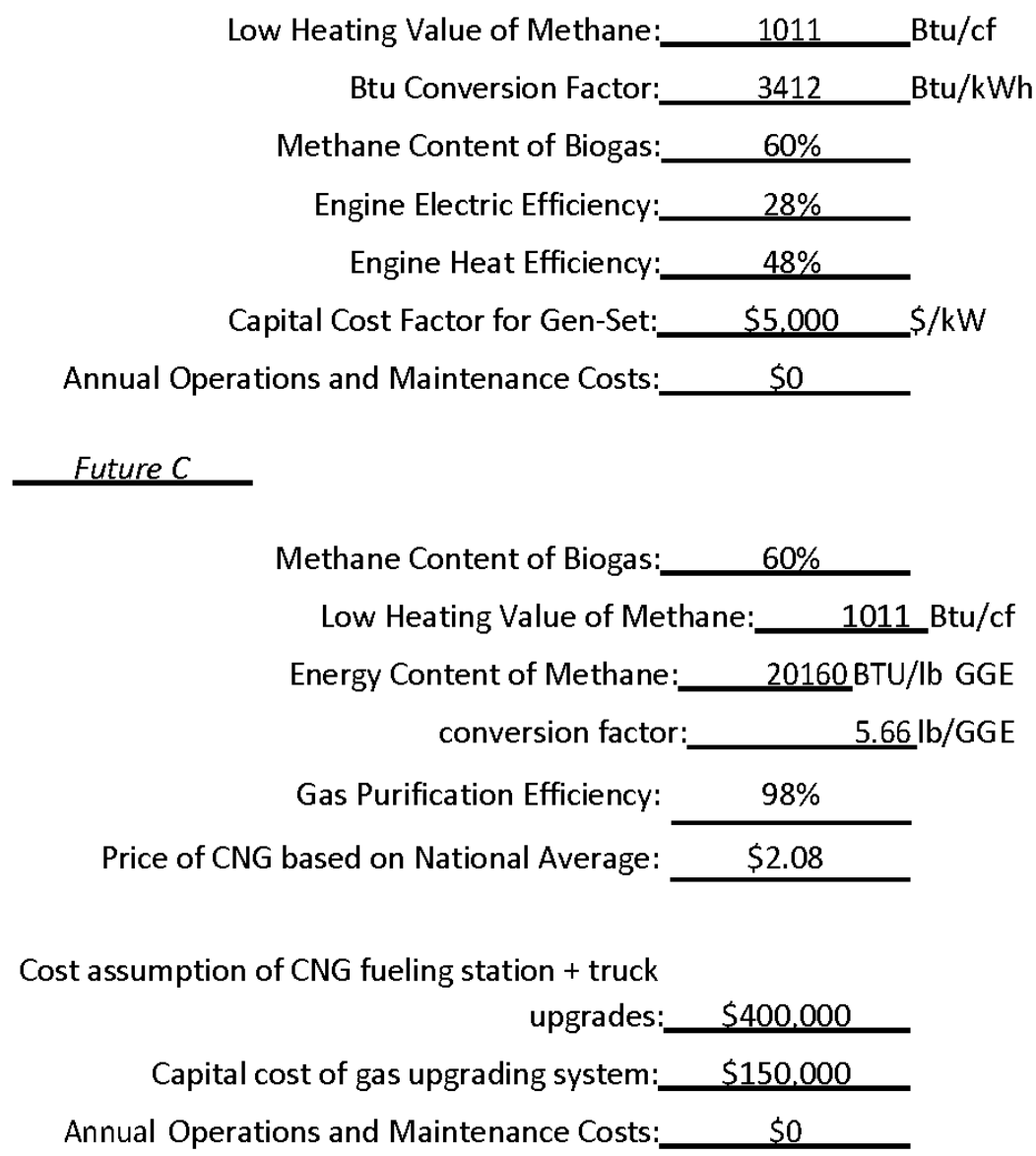




\section{Scenario 3}

The Scenario 3 simulation was conducted on 29 November 2016, with no $\mathrm{AD}$. Scenario 3 variables are given below and on the pages that follow.

\section{GUI Input Variables}

\section{Digester}

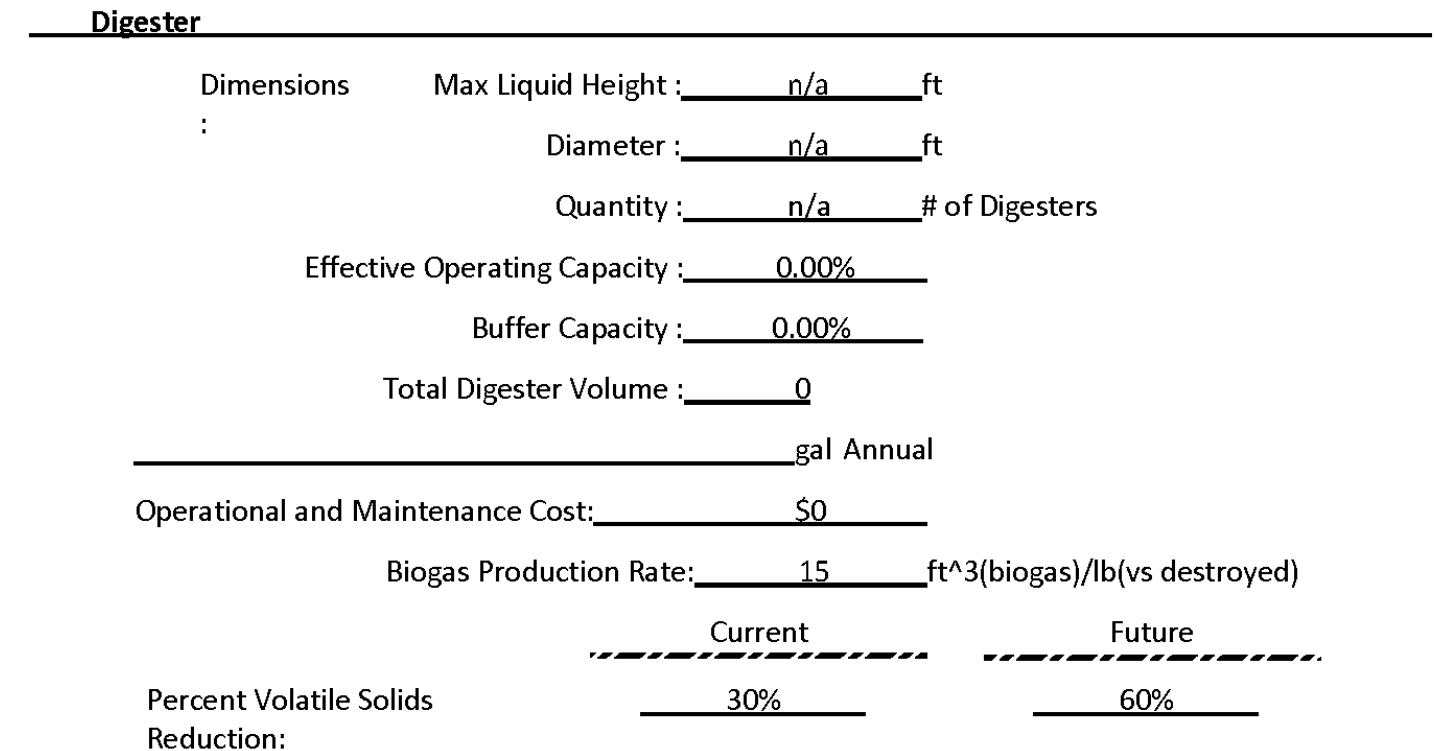

Feedstocks

\begin{tabular}{llcccccc} 
& & Time of & & Units \\
Use & Feedstock & Quantity & per Day & $\begin{array}{c}\text { Specific } \\
\text { Gravity }\end{array}$ & $\begin{array}{c}\text { Total Solids } \\
\text { (\%) }\end{array}$ & $\begin{array}{c}\text { VS/TS } \\
\text { Ratio }\end{array}$ \\
\cline { 2 - 7 } \#1 & Waste Activated Sludge (WAS) & Both & 7650 & Gal. & 1 & 2 & 0.75 \\
\#2 & Brown Grease & Future & 548 & Gal. & 1 & 29.9 & 0.96 \\
\#3 & Cooking Oil & Future & 400 & Gal. & 1 & 90 & 0.96 \\
\#4 & DFAC Food & Future & 400 & Gal. & 1 & 30 & 0.85 \\
\#5 & Other Food & Future & 450 & Gal. & 1 & 30 & 0.85 \\
\#6 & Horse Manure & Future & 300 & Gal. & 1 & 40 & 0.8
\end{tabular}

Percent Solids Fed to Digester:

Hydraulic retention Time:
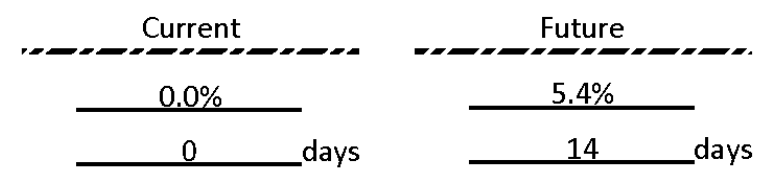
Economics

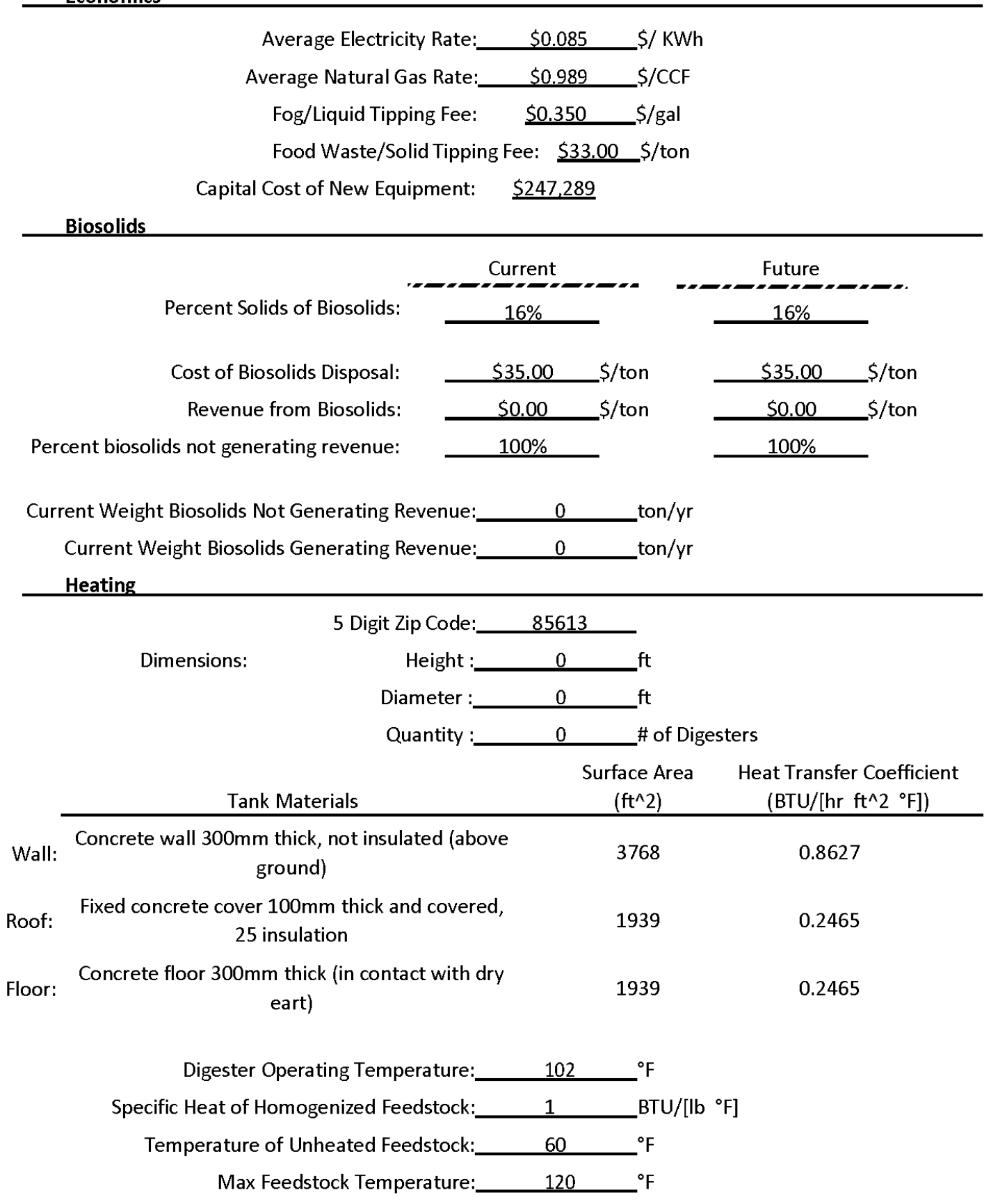




\section{Biogas Use Variables}

Economics

Discount Rate: $\frac{4 \%}{4 \%}$
Analysis Period: $\frac{15}{15.00 \%}$

Future Biogas Use Scenario Variables

Future A

Heat Recovery Efficiency:__ $\quad 75 \%$

Future B

\begin{tabular}{|c|c|}
\hline Low Heating Value of Methane: & 1011 \\
\hline Btu Conversion Factor: & 3412 \\
\hline Methane Content of Biogas: & $60 \%$ \\
\hline Engine Electric Efficiency:_ & $28 \%$ \\
\hline Engine Heat Efficiency:_ & $48 \%$ \\
\hline Capital Cost Factor for Gen-Set: & $\$ 5.000$ \\
\hline ations and Maintenance Cos & $\$ \mathbf{s}_{0}$ \\
\hline
\end{tabular}

Annual Operations and Maintenance Costs

Future C

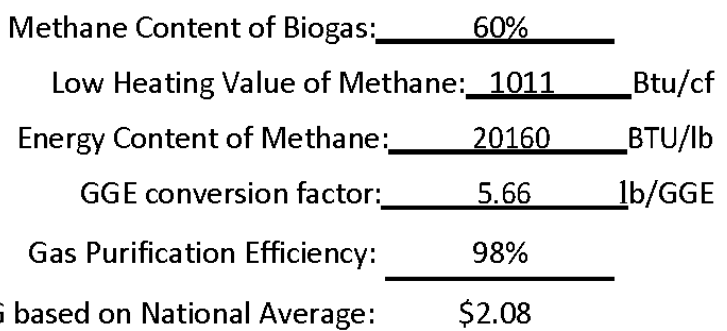

Cost assumption of CNG fueling station + truck upgrades: Capital cost of gas upgrading system: $\$ 400,000$

Annual Operations and Maintenance Costs: $\$ 150.000$ 


\section{Scenario 4}

The Scenario 4 simulation was conducted on 30 November 2016, with no $\mathrm{AD}$. Scenario 4 variables are given below and on the pages that follow.

\section{GUI Input Variables}

Digester

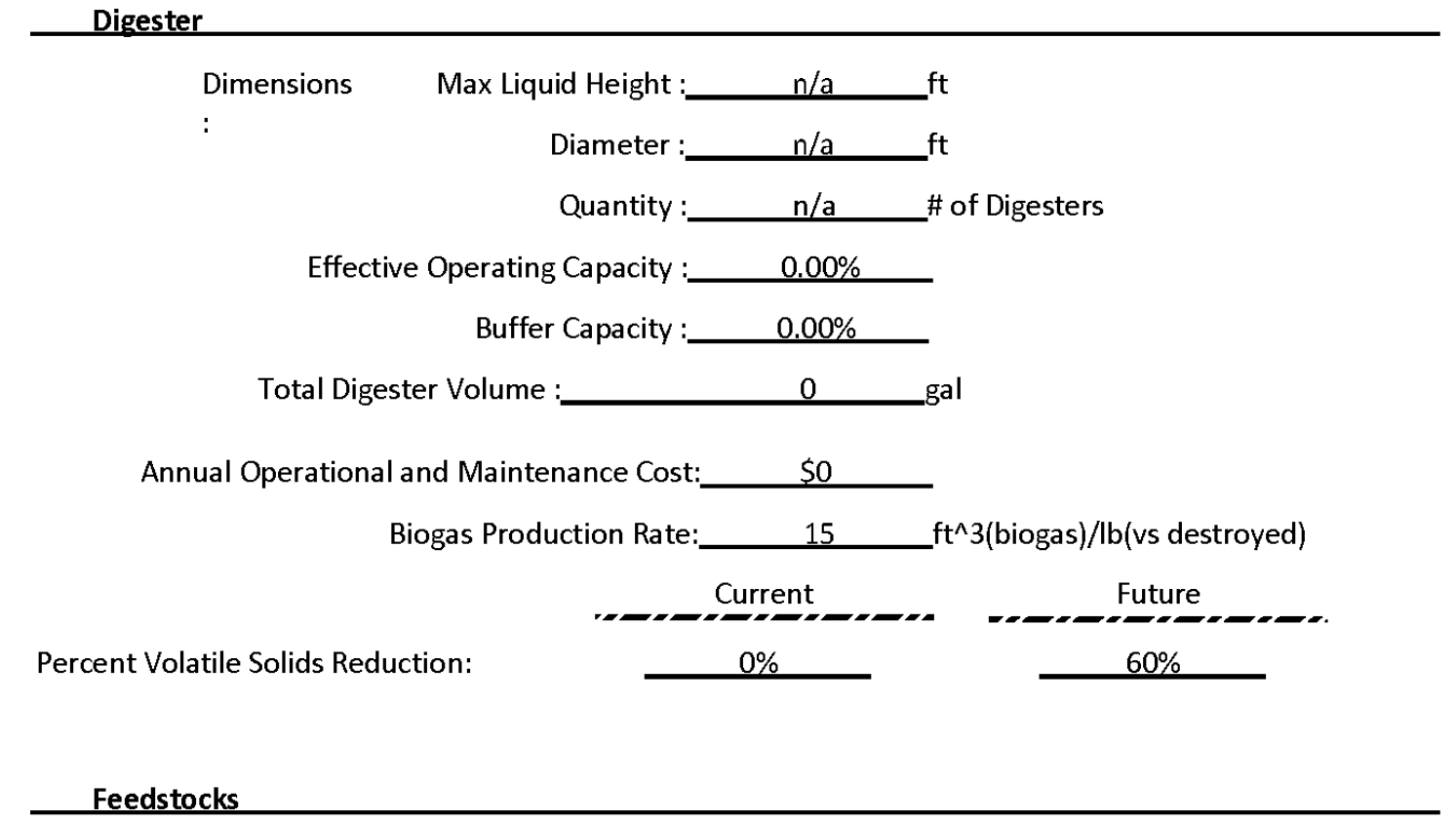

\begin{tabular}{llcccccc} 
& & Time of & & Units & Specific & Total Solids & VS/TS \\
(\%) & Geedstock & Quantity & per Day & Gravity & Ratio \\
\cline { 2 - 8 } \#1 & Waste Activated Sludge (WAS) & Future & 15000 & Gal. & 1 & 0.5 & 0.75 \\
\#2 & Brown Grease & Future & 548 & Gal. & 1 & 29.9 & 0.96 \\
\#3 & Cooking Oil & Future & 400 & Gal. & 1 & 90 & 0.96 \\
\#4 & DFAC Food & Future & 400 & Gal. & 1 & 30 & 0.85 \\
\#5 & Other Food & Future & 450 & Gal. & 1 & 30 & 0.85 \\
\#6 & Horse Manure & Future & 300 & Gal. & 1 & 40 & 0.8 \\
\#7 & Waste Activated Sludge (WAS) & Current & 15000 & Gal. & 1 & 0.5 & 0.75
\end{tabular}

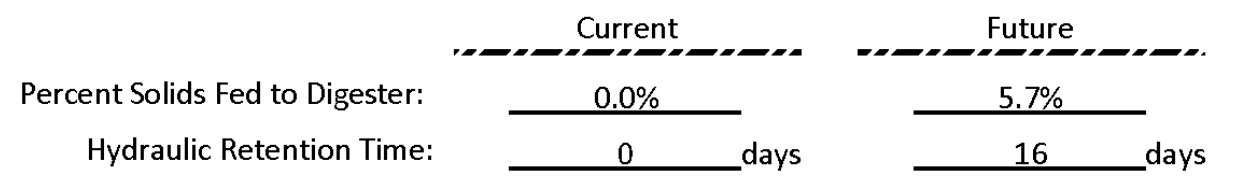


Economics

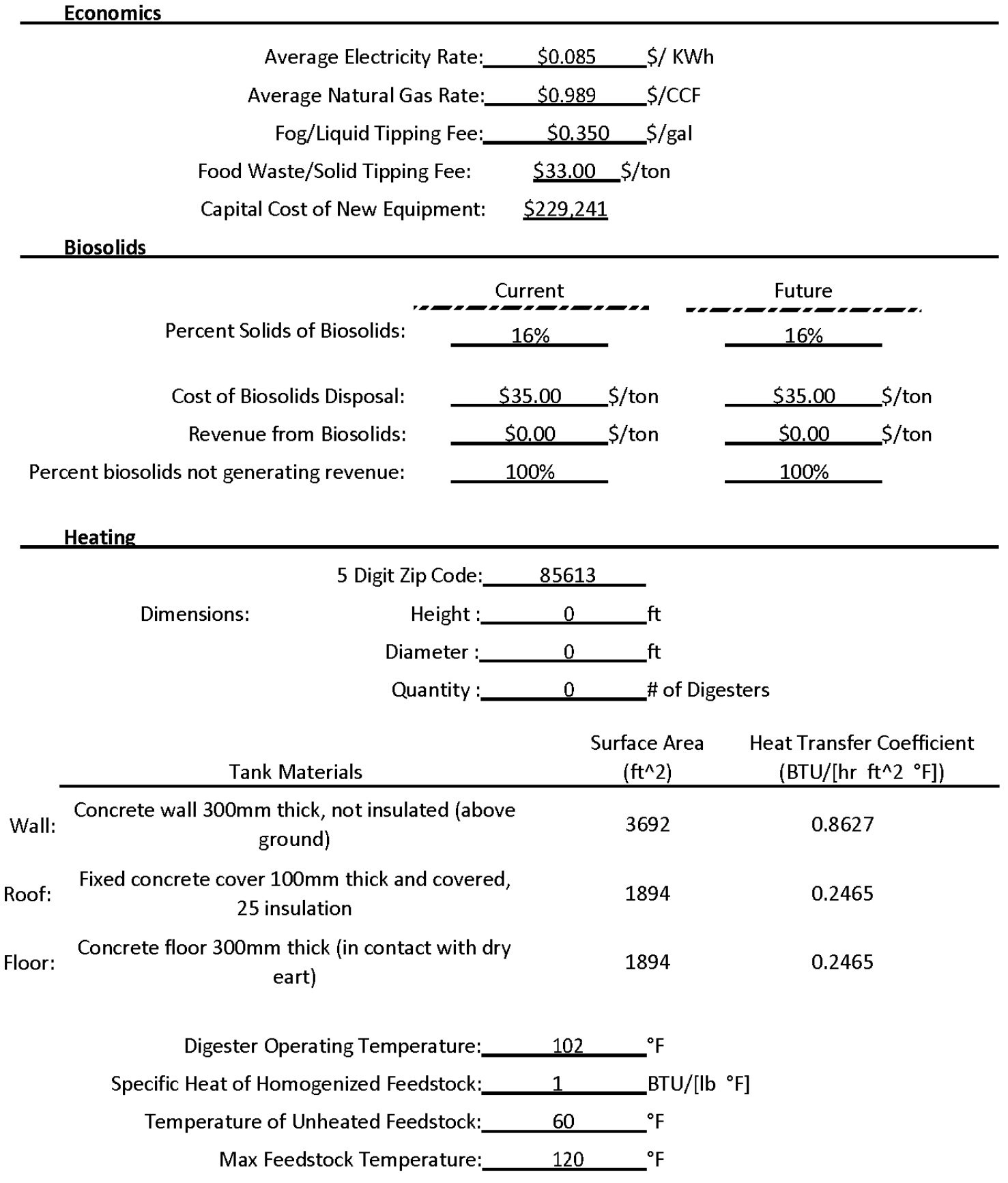




\section{Biogas Use Variables}

Economics

Discount Rate: $\frac{4 \%}{4 \%}$
Analysis Period: $\frac{15}{15.00 \%}$

Future Biogas Use Scenario Variables

Future A

Heat Recovery Efficiency: $\quad 75 \%$

Future B

\begin{tabular}{|c|c|c|}
\hline Low Heating Value of Methane: & 1011 & _Btu/cf \\
\hline Btu Conversion Factor: & 3412 & _Btu/kWh \\
\hline Methane Content of Biogas: & $60 \%$ & \\
\hline Engine Electric Efficiency:_ & $28 \%$ & \\
\hline Engine Heat Efficiency:_ & $48 \%$ & \\
\hline Capital Cost Factor for Gen-Set: & $\$ 5,000$ & $\$ / \mathrm{kW}$ \\
\hline
\end{tabular}

Annual Operations and Maintenance Costs:

$\$ 0$

Future $C$

\begin{tabular}{|c|c|}
\hline Methane Content of Biogas: & $60 \%$ \\
\hline Low Heating Value of Met & : 1011 \\
\hline Energy Content of Methane: & 20160 \\
\hline GGE conversion factor: & 5.66 \\
\hline Gas Purification Efficiency: & $98 \%$ \\
\hline based on National Average: & $\$ 2.08$ \\
\hline
\end{tabular}

Cost assumption of CNG fueling station + truck

upgrades: $\$ 400.000$

Capital cost of gas upgrading system: $\quad \$ 150.000$

Annual Operations and Maintenance Costs:

$\$ 0$ 


\section{Scenario 5}

The Scenario 5 simulation was conducted on 30 November 2016, with no $\mathrm{AD}$. Scenario 5 variables are given below and on the pages that follow.

\section{GUI Input Variables}

\section{Digester}

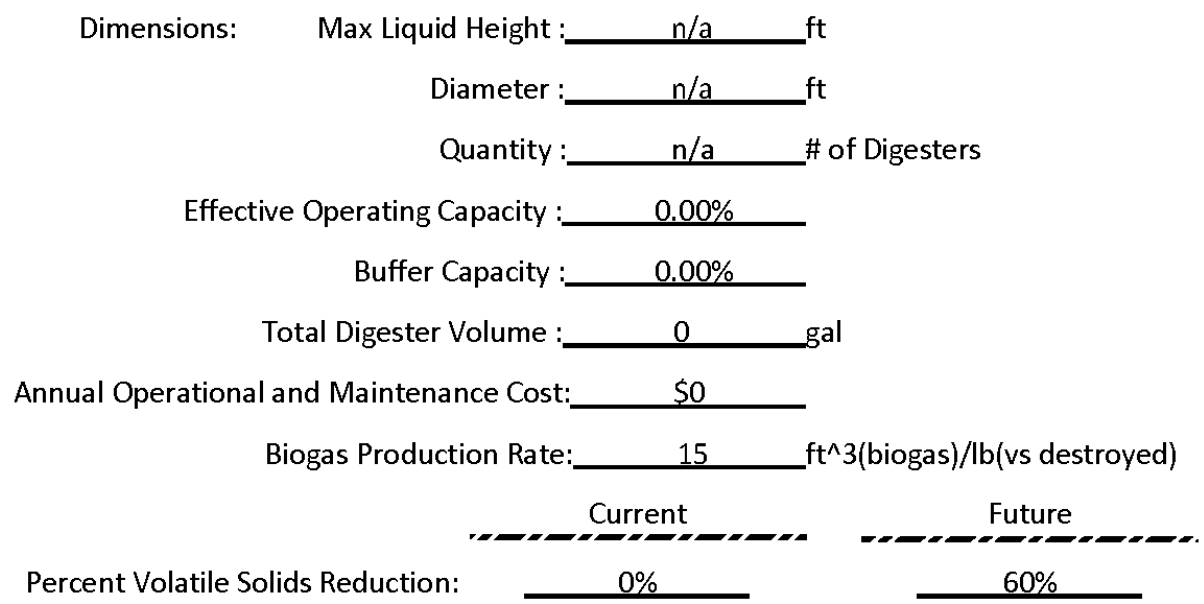

\section{Feedstocks}

\begin{tabular}{llcccccc} 
& & Time of & & Units & Specific & Total Solids & VS/TS \\
Use & Quantity & per Day & Gravity & (\%) & Ratio \\
\cline { 2 - 7 } \#1 & Waste Activated Sludge (WAS) & Future & 15150 & Gal. & 1 & 1 & 0.75 \\
$\# 2$ & Brown Grease & Future & 548 & Gal. & 1 & 29.9 & 0.96 \\
$\# 3$ & Cooking Oil & Future & 400 & Gal. & 1 & 90 & 0.96 \\
$\# 4$ & DFAC Food & Future & 400 & Gal. & 1 & 30 & 0.85 \\
\#5 & Other Food & Future & 450 & Gal. & 1 & 30 & 0.85 \\
\#6 & Horse Manure & Future & 300 & Gal. & 1 & 40 & 0.8
\end{tabular}

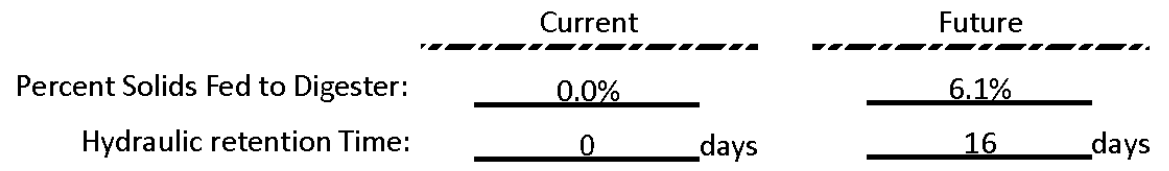


Economics

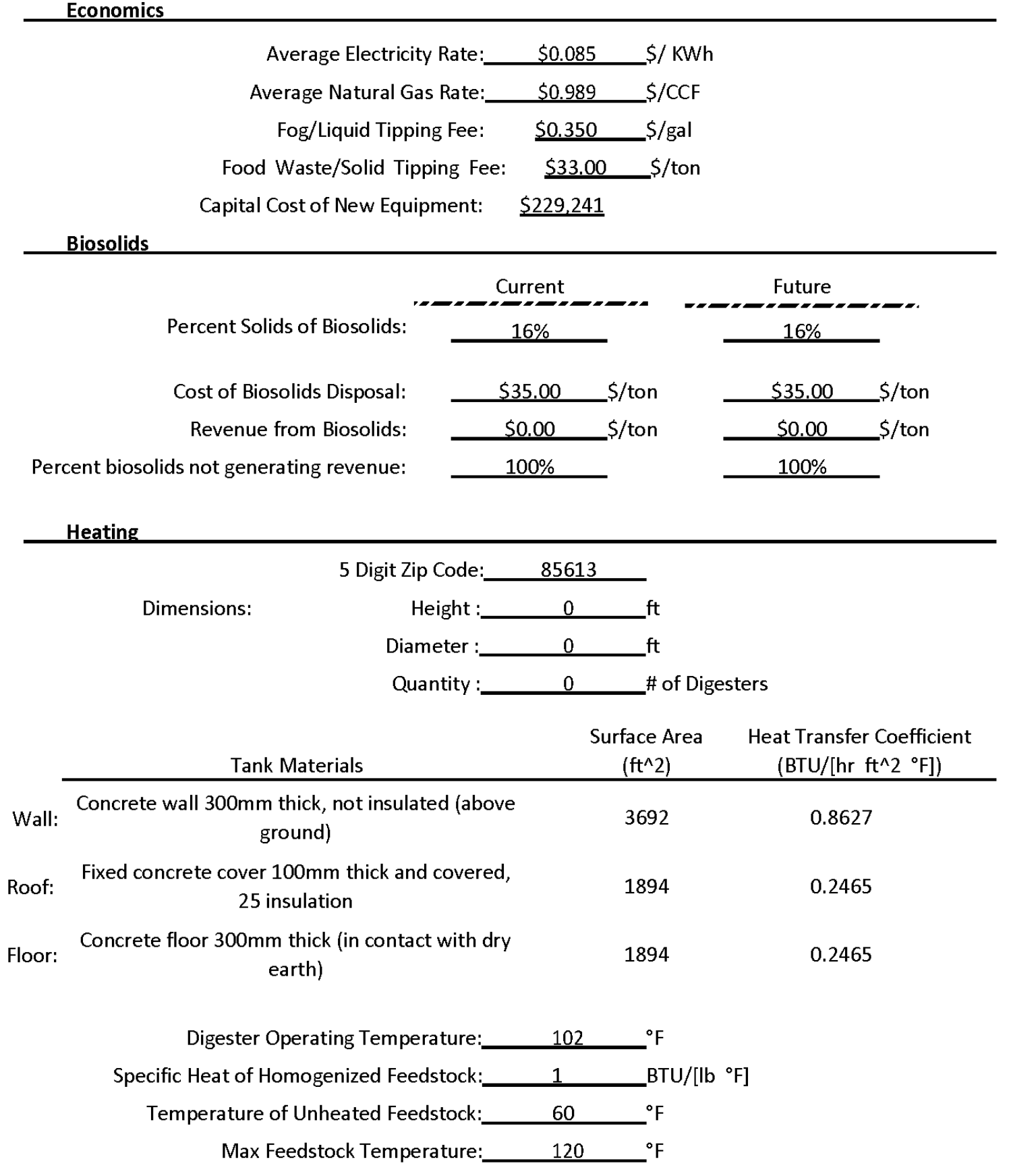




\section{Biogas Use Variables}

Economics

$\begin{array}{rc}\text { Discount Rate: } & 4 \% \\ \text { Analysis Period: } & 15 \\ \text { Engineering \& Installation Factor: } & 15.00 \%\end{array}$

Future Biogas Use Scenario Variables

Future A

Heat Recovery Efficiency: $\quad 75 \%$

Future B

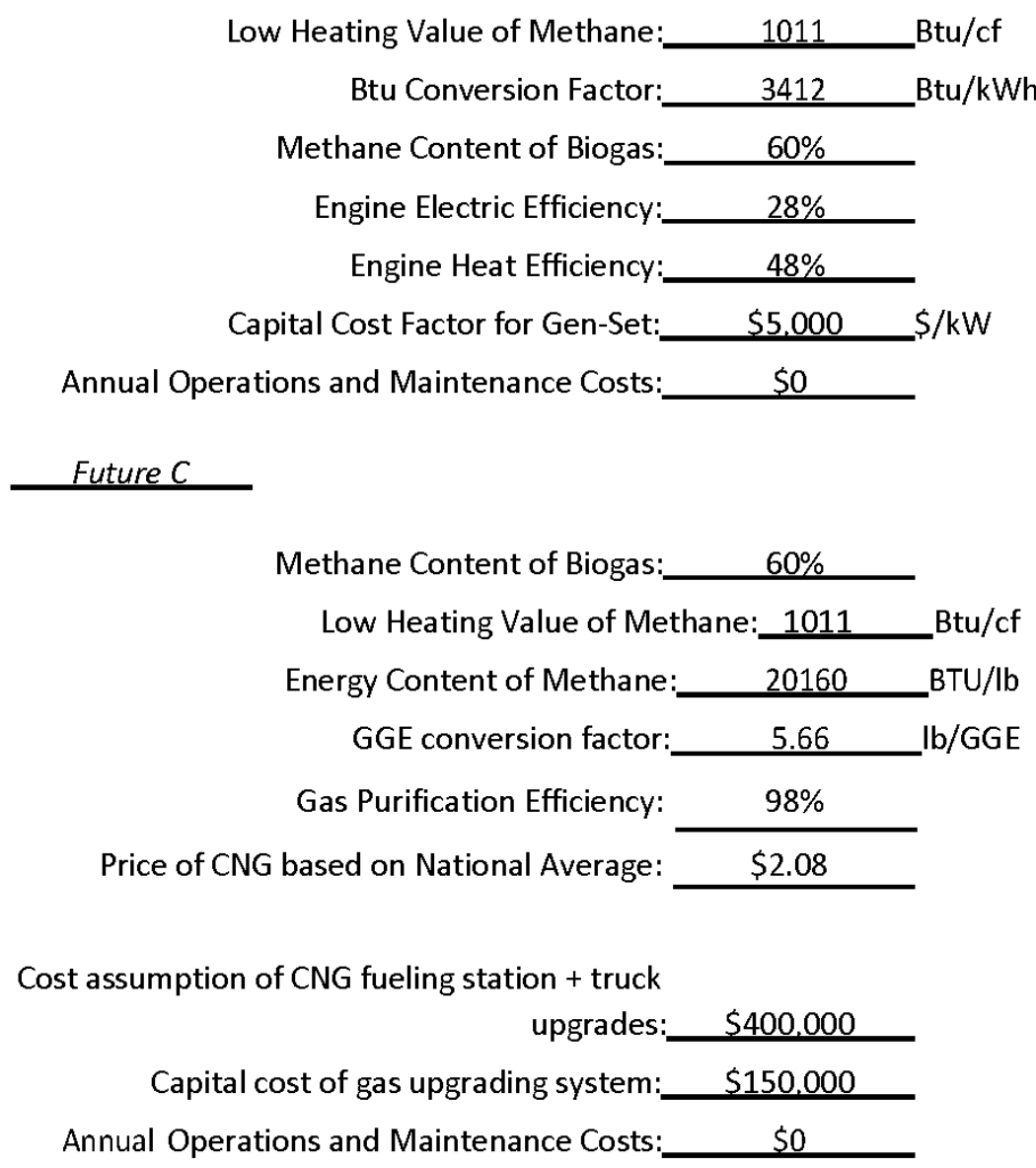




\section{Scenario 6}

The Scenario 6 simulation was conducted 12 December 2016, and it is the only one using AD. Scenario 6 variables are given below and on the pages that follow.

\section{GUI Input Variables}

\section{Digester}

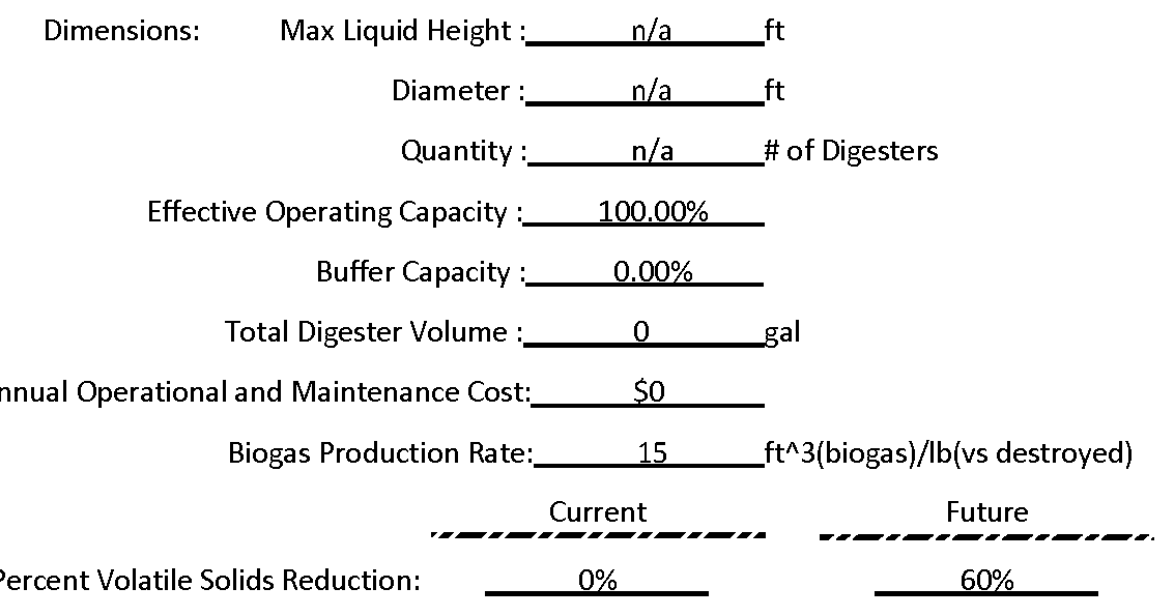

Feedstocks

\begin{tabular}{llcccccc} 
& Time of & & Units & Specific & Total Solids & VS/TS \\
Use & Quantity & per Day & Gravity & $\begin{array}{c}\text { (\%) } \\
\text { Ratio }\end{array}$ \\
\cline { 2 - 8 } \#1 & Waste Activated Sludge (WAS) & Future & 15150 & Gal. & 1 & 1 & 0.75 \\
\#2 & Brown Grease & Future & 548 & Gal. & 1 & 29.9 & 0.96 \\
$\# 3$ & Cooking Oil & Future & 400 & Gal. & 1 & 90 & 0.96 \\
$\# 4$ & DFAC Food & Future & 400 & Gal. & 1 & 30 & 0.85 \\
$\# 5$ & Other Food & Future & 450 & Gal. & 1 & 30 & 0.85 \\
\#6 & Horse Manure & Future & 300 & Gal. & 1 & 40 & 0.8
\end{tabular}

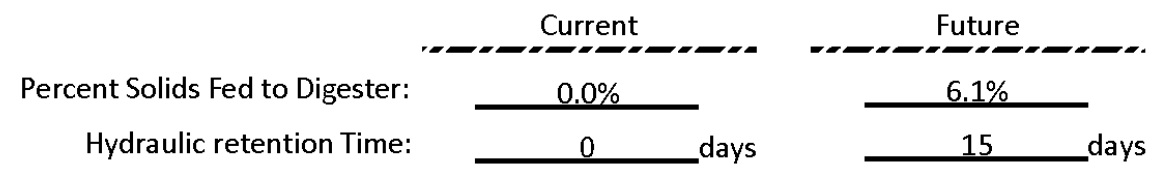


Economics

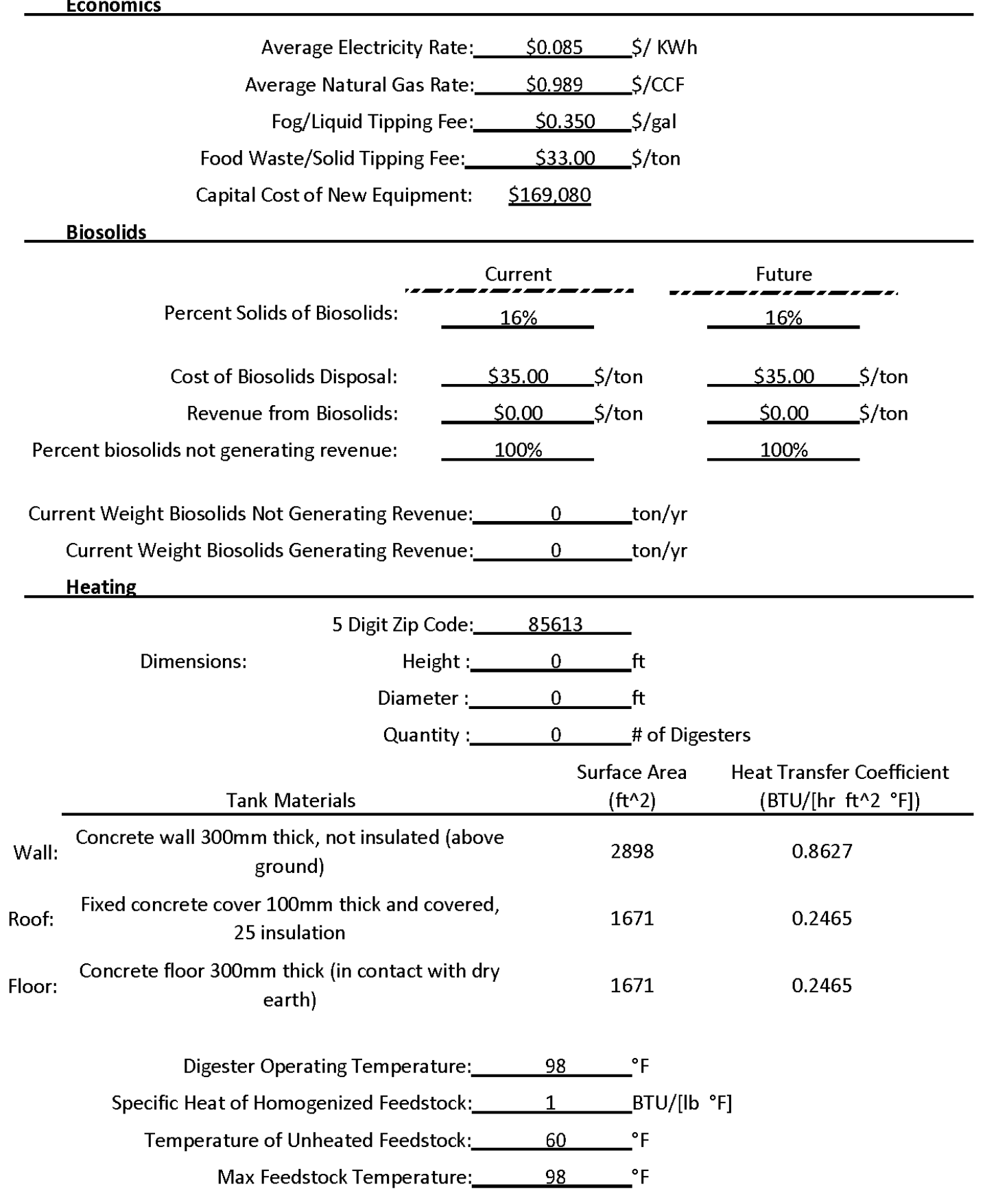




\section{Biogas Use Variables}

Economics

Discount Rate:

$4 \%$

Analysis Period: 15

Engineering \& Installation Factor: $15.00 \%$

Future Biogas Use Scenario Variables

Future A

Heat Recovery Efficiency:

$75 \%$

Future B

\begin{tabular}{|c|c|c|}
\hline Low Heating Value of Methane: & 1011 & Btu/cf \\
\hline Btu Conversion Factor: & 3412 & Btu/kWh \\
\hline Methane Content of Biogas: & $60 \%$ & \\
\hline Engine Electric Efficiency: & $28 \%$ & \\
\hline Engine Heat Efficiency: & $48 \%$ & \\
\hline Capital Cost Factor for Gen-Set & $\$ 5,000$ & $\$ / \mathrm{kW}$ \\
\hline
\end{tabular}

Annual Operations and Maintenance Costs: $\$ 0$

Future C

\begin{tabular}{|c|c|}
\hline Methane Content of Biogas:_ & $60 \%$ \\
\hline Low Heating Value of Metr & e: 1011 \\
\hline Energy Content of Methane: & 20160 \\
\hline GGE conversion factor: & 5.66 \\
\hline Gas Purification Efficiency: & $98 \%$ \\
\hline based on National Aver & $\$ 2.08$ \\
\hline
\end{tabular}

Cost assumption of CNG fueling station + truck

$$
\text { upgrades: }
$$

Capital cost of gas upgrading system:

$\$ 400,000$

$\$ 150.000$

Annual Operations and Maintenance Costs: \$0 


\section{Appendix E: Calculations and Assumptions for Heating Demand in Co-EAT Scenarios}

The following calculations relate to the Scenarios 1-6 that were presented in Appendix D. There are two groups of calculations per scenario.

\section{Scenario 1: Equivalent surface area calculations and assumptions}

$$
\begin{aligned}
& S A_{T}=S A_{A C I D}+S A_{M E T H} \\
& \text { SA of Acid Tank Calculation } \\
& \text { SA of Methane Tank Calculation } \\
& V_{A C I D}=45000 \mathrm{gal} \\
& V_{\text {METH }}=250000 \mathrm{gal} \\
& \text { Assuming a cylindrical tank, } \\
& r_{A C I D}=\sqrt{\frac{V_{A C I D}}{\pi \times h_{A C I D}}} \\
& \text { Assuming a cylindrical tank, } \\
& \text { Where, } \\
& h=20 \mathrm{ft} \\
& \text { Conversion Factor: } 7.48 \mathrm{gal} / \mathrm{cf} \\
& r_{M E T H}=\sqrt{\frac{V_{M E T H}}{\pi \times h_{M E T H}}} \\
& \text { Where, } \\
& h=20 \quad \mathrm{ft} \\
& \text { Conversion Factor: } \quad 7.48 \mathrm{gal} / \mathrm{cf} \\
& \begin{array}{c}
r_{A C I D}=\sqrt{\frac{45,000 g a l}{\pi \times 20 f t \times 7.48 \frac{g a l}{c f}}} \\
r_{A C D}=9.8 \mathrm{ft}
\end{array} \\
& r_{M E T H}=\sqrt{\frac{250,000 \mathrm{gal}}{\pi \times 20 \mathrm{ft} \times 7.48 \frac{g a l}{c f}}} \\
& S A_{A C I D-W a l l}=2 \times \pi \times r_{A C I D} \times h_{A C I D} \\
& S A_{A C I D-W a l l}=1230 \mathrm{sf} \\
& S A_{A C I D-R o o f}=\pi \times r_{A C I D}{ }^{2} \\
& S A_{A C I D-R o o f}=301 \\
& S A_{A C I D-F l o o r}=S A_{A C I D-R o o f} \\
& r_{M E T H}=\underbrace{23.1} \mathrm{ft} \\
& S A_{\text {METH-Wall }}=2 \times \pi \times r_{A C I D} \times h_{A C I D} \\
& S A_{\text {METH-Wall }}=2898 \mathrm{sf} \\
& S A_{M E T H-R o o f}=\pi \times r_{A C I D}{ }^{2} \\
& S A_{\text {METH-Roof }}=1671 \text { sf } \\
& S A_{\text {METH-Floor }}=S A_{\text {METH-Roof }} \\
& S A_{A C I D-F l o o r}=301 \text { sf } \\
& S A_{A C I D}=1831 s f \\
& S A_{T-\text { Wall }}=4128 \mathrm{sf} \\
& S A_{T-\text { Roof }}=1972 \mathrm{sf} \\
& S A_{T-\text { Floor }}=1972 \mathrm{sf} \\
& S A_{\text {METH }}=6241
\end{aligned}
$$


Scenario 1: Weighted digester operating temperature calculation

$$
\begin{gathered}
T_{e q}=\frac{T_{A C I D} \times S A_{A C I D}+T_{M E T H} \times S A_{M E T H}}{S A_{T}} \\
T_{A C I D}=\frac{120}{T_{M E T H}}{ }^{\circ} \mathrm{F} \\
T_{e q}{ }^{\circ} \mathrm{F} \\
T_{\text {. }}=\frac{120^{\circ} \mathrm{F} \times 1831 \mathrm{ft}^{2}+98^{\circ} \mathrm{F} \times 6241 \mathrm{ft}^{2}}{1831 \mathrm{ft}^{2}+6241 \mathrm{ft}^{2}} \\
T_{e q}=\frac{103}{}^{\circ} \mathrm{F}
\end{gathered}
$$




\section{Scenario 2: Equivalent surface area calculations and assumptions}

$S A_{T}=S A_{A C I D}+S A_{M E T H}$

SA of Acid Tank Calculation

$V_{A C I D}=15000$ gal

Assuming a cylindrical tank,

$$
r_{A C I D}=\sqrt{\frac{V_{A C I D}}{\pi \times h_{A C I D}}}
$$

Where,

$h=15 \mathrm{ft}$

Conversion Factor: $7.48 \mathrm{gal} / \mathrm{cf}$

$$
\begin{gathered}
r_{A C I D}=\sqrt{\frac{15,000 \mathrm{gal}}{\pi \times 15 f t \times 7.48 \frac{g a l}{c f}}} \\
r_{A C I D}={ }^{6.5} \mathrm{ft}
\end{gathered}
$$$$
S A_{A C I D-W a l l}=2 \times \pi \times r_{A C I D} \times h_{A C I D}
$$$$
S A_{A C I D-W a l l}=615 \mathrm{sf}
$$$$
S A_{A C I D-R o o f}=\pi \times r_{A C I D}{ }^{2}
$$$$
S A_{A C I D-R o o f}=134 \mathrm{sf}
$$$$
S A_{A C I D-F l o o r}=S A_{A C I D-R o o f}
$$$$
S A_{A C I D-F l o o r}=134 \text { sf }
$$$$
S A_{A C I D}=882 \mathrm{sf}
$$$$
S A_{T-\text { Wall }}=3513 \text { sf }
$$$$
S A_{T-R o o f}=1805 \text { sf }
$$$$
S A_{T-\text { Floor }}=1805 \mathrm{sf}
$$

SA of Methane Tank Calculation

$V_{\text {METH }}=250000 \mathrm{gal}$

Assuming a cylindrical tank,

$$
r_{M E T H}=\sqrt{\frac{V_{M E T H}}{\pi \times h_{M E T H}}}
$$

Where,

$$
h=20{ }^{\mathrm{ft}}
$$

Conversion Factor: 7.48 gal/cf

$$
\begin{gathered}
r_{M E T H}=\sqrt{\frac{250,000 \mathrm{gal}}{\pi \times 20 f t \times 7.48 \frac{g a l}{c f}}} \\
r_{M E T H}=23.1 \mathrm{ft}
\end{gathered}
$$

$S A_{M E T H-W a l l}=2 \times \pi \times r_{A C I D} \times h_{A C I D}$

$S A_{\text {METH-Wall }}=2898$ sf

$S A_{M E T H-R o o f}=\pi \times r_{A C I D}{ }^{2}$

$S A_{\text {METH-Roof }}=1671$ sf

$S A_{M E T H-F l o o r}=S A_{M E T H-R o o f}$

$S A_{\text {METH-Floor }}=1671 \mathrm{sf}$

$S A_{\text {METH }}=6241$ 


\section{Scenario 2: Weighted operating temperature calculation}

$$
\begin{gathered}
T_{e q}=\frac{T_{A C I D} \times S A_{A C I D}+T_{M E T H} \times S A_{M E T H}}{S A_{T}} \\
T_{A C I D}=\frac{120}{T_{M E T H}}=\frac{98}{{ }^{\circ} \mathrm{F}}{ }^{\circ} \mathrm{F} \\
T_{e q}=\frac{120^{\circ} \mathrm{F} \times 882 f t^{2}+98^{\circ} \mathrm{F} \times 6241 \mathrm{ft}^{2}}{882 f t^{2}+6241 \mathrm{ft}^{2}} \\
T_{e q}=\frac{101}{{ }^{\circ} \mathrm{F}}
\end{gathered}
$$




\section{Scenario 3: Equivalent surface area calculations and assumptions:}

$$
S A_{T}=S A_{A C I D}+S A_{M E T H}
$$

SA of Acid Tank Calculation

$V_{A C I D}=30000 \mathrm{gal}$

Assuming a cylindrical tank,

$$
r_{A C I D}=\sqrt{\frac{V_{A C I D}}{\pi \times h_{A C I D}}}
$$

Where,

$$
\mathrm{h}=15 \mathrm{ft}
$$

Conversion Factor: 7.48 gal/cf

$$
\begin{aligned}
& r_{A C I D}=\sqrt{\frac{30,000 \mathrm{gal}}{\pi \times 15 f t \times 7.48 \frac{g a l}{c f}}} \\
& r_{A C I D}=9.2{ }^{\mathrm{ft}} \\
& S A_{A C I D-\text { Wall }}=2 \times \pi \times r_{A C I D} \times h_{A C I D} \\
& S A_{A C I D-\text { Wall }}=869 \mathrm{sf} \\
& S A_{A C I D-R o o f}=\pi \times r_{A C I D}{ }^{2} \\
& S A_{A C I D-R o o f}=267 \text { sf } \\
& S A_{A C I D-F l o o r}=S A_{A C I D-R o o f} \\
& S A_{A C I D-F l o o r}=267 \mathrm{sf} \\
& S A_{A C I D}=1404 \text { sf } \\
& S A_{T-\text { Wall }}=3768 \mathrm{sf} \\
& S A_{T-\text { Roof }}=1939 \mathrm{sf} \\
& S A_{T-\text { Floor }}=1939 \mathrm{sf}
\end{aligned}
$$

$$
\text { SA of Methane Tank Calculation }
$$

$V_{M E T H}=250000$ gal

Assuming a cylindrical tank,

$$
r_{M E T H}=\sqrt{\frac{V_{M E T H}}{\pi \times h_{M E T H}}}
$$

Where,

$$
\mathrm{h}=20 \mathrm{ft}
$$

Conversion Factor: $7.48 \mathrm{gal} / \mathrm{cf}$

$$
\begin{gathered}
r_{M E T H}=\sqrt{\frac{250,000 g a l}{\pi \times 20 f t \times 7.48 \frac{g a l}{c f}}} \\
r_{M E T H}=23.1 \\
\end{gathered}
$$

$$
S A_{\text {METH-Wall }}=2 \times \pi \times r_{A C I D} \times h_{A C I D}
$$$$
S A_{\text {METH-Wall }}=2898 \mathrm{sf}
$$$$
S A_{M E T H-R o o f}=\pi \times r_{A C I D}^{2}
$$$$
S A_{M E T H-R o o f}=1671 \mathrm{sf}
$$$$
S A_{M E T H-F l o o r}=S A_{M E T H-R o o f}
$$

$S A_{\text {METH-Floor }}=1671^{s f}$

$$
S A_{\text {METH }}=\quad 6241
$$


Scenario 3: Weighted digester operating temperature calculation

$$
\begin{gathered}
T_{e q}=\frac{T_{A C I D} \times S A_{A C I D}+T_{M E T H} \times S A_{M E T H}}{S A_{T}} \\
T_{A C I D}=\frac{120}{98}^{\circ} \mathrm{F} \\
T_{M E T H} \mathrm{~F} \\
T_{e q}=\frac{120^{\circ} \mathrm{F} \times 1404 f t^{2}+98^{\circ} \mathrm{F} \times 6241 \mathrm{ft}^{2}}{1404 \mathrm{ft}^{2}+6241 \mathrm{ft}^{2}} \\
T_{e q}=\frac{102}{{ }^{\circ} \mathrm{F}}
\end{gathered}
$$




\section{Scenario 4: Equivalent surface area calculations and assumptions}

$S A_{T}=S A_{A C I D}+S A_{M E T H}$

SA of Acid Tank Calculation

$V_{A C I D}=25000$ gal

Assuming a cylindrical tank,

$$
r_{A C I D}=\sqrt{\frac{V_{A C I D}}{\pi \times h_{A C I D}}}
$$

Where,

$$
\mathrm{h}=15 \mathrm{ft}
$$

Conversion Factor: 7.48 gal/cf

$$
\begin{aligned}
& r_{A C I D}=\sqrt{\frac{25,000 \mathrm{gal}}{\pi \times 15 f t \times 7.48 \frac{g a l}{c f}}} \\
& r_{A C I D}={ }^{8.4}{ }^{\mathrm{ft}} \\
& S A_{A C I D-W a l l}=2 \times \pi \times r_{A C I D} \times h_{A C I D} \\
& S A_{A C I D-W a l l}=794 \quad s f \\
& S A_{A C I D-R o o f}=\pi \times r_{A C I D}{ }^{2} \\
& S A_{A C I D-R o o f}=223 \mathrm{sf} \\
& S A_{A C I D-F l o o r}=S A_{A C I D-R o o f} \\
& S A_{A C I D-F l o o r}=223 \text { sf } \\
& S A_{A C I D}=1239 \text { sf } \\
& S A_{T-\text { Wall }}=3692 \mathrm{sf} \\
& S A_{T-\text { Roof }}=1894 \mathrm{sf} \\
& S A_{T-\text { Floor }}=1894 \mathrm{sf}
\end{aligned}
$$

\section{SA of Methane Tank Calculation}

$V_{\text {METH }}=250000 \mathrm{gal}$

Assuming a cylindrical tank,

$$
r_{M E T H}=\sqrt{\frac{V_{M E T H}}{\pi \times h_{M E T H}}}
$$

Where,

$$
\mathrm{h}=20 \mathrm{ft}
$$

Conversion Factor: 7.48 gal/cf

$$
\begin{gathered}
r_{M E T H}=\sqrt{\frac{250,000 g a l}{\pi \times 20 f t \times 7.48 \frac{g a l}{c f}}} \\
r_{M E T H}=23.1 \\
\end{gathered}
$$

$S A_{\text {METH-Wall }}=2 \times \pi \times r_{A C I D} \times h_{A C I D}$

$S A_{\text {METH-Wall }}=2898 \mathrm{sf}$

$S A_{M E T H-R o o f}=\pi \times r_{A C I D}{ }^{2}$

$S A_{M E T H-R O o f}=1671$ sf

$S A_{\text {METH-Floor }}=S A_{\text {METH-Roof }}$

$S A_{\text {METH-Floor }}=1671$ sf

$S A_{\text {METH }}=6241$ 
Scenario 4: Weighted digester operating temperature calculation

$$
\begin{gathered}
T_{e q}=\frac{T_{A C I D} \times S A_{A C I D}+T_{M E T H} \times S A_{M E T H}}{S A_{T}} \\
T_{A C I D}=\frac{120{ }^{\circ} \mathrm{F}}{T_{M E T H}}=\frac{98}{\circ} \mathrm{F}_{T_{e q}}=\frac{120^{\circ} \mathrm{F} \times 1239 \mathrm{ft}^{2}+98^{\circ} \mathrm{F} \times 6241 \mathrm{ft}^{2}}{1239 \mathrm{ft}^{2}+6241 \mathrm{ft}^{2}} \\
T_{e q}=\frac{102}{102}^{\circ} \mathrm{F}
\end{gathered}
$$

Scenario 5: Equivalent surface area calculations and assumptions

These calculations and assumptions are the same as for Scenario 4 .

Scenario 5: Weighted digester operating temperature calculation

This calculation is the same as for Scenario 4 . 


\section{Scenario 6: Equivalent surface area calculations and assumptions}

$$
\begin{aligned}
& S A_{T}=S A_{A C I D}+S A_{M E T H} \\
& \text { SA of Acid Tank Calculation } \\
& \text { SA of Methane Tank Calculation } \\
& V_{A C I D}= \\
& \text { gal } \\
& V_{M E T H}=250000 \mathrm{gal} \\
& r_{A C I D}=\sqrt{\frac{V_{A C I D}}{\pi \times h_{A C I D}}} \\
& h=15 \mathrm{ft} \\
& \text { Conversion Factor: } 7.48 \mathrm{gal} / \mathrm{cf} \\
& r_{A C I D}=\sqrt{\frac{0 \text { gal }}{\pi \times 15 f t \times 7.48 \frac{g a l}{c f}}} \\
& r_{A C I D}=0.0 \mathrm{ft} \\
& S A_{A C I D-W a l l}=2 \times \pi \times r_{A C I D} \times h_{A C I D} \\
& S A_{A C I D-W a l l}={ }^{0} \mathrm{sf} \\
& S A_{A C I D-R o o f}=\pi \times r_{A C I D}{ }^{2} \\
& S A_{A C I D-R o o f}=0 \quad 0 \quad s f \\
& S A_{A C I D-F l o o r}=S A_{A C I D-R o o f} \\
& S A_{A C I D-F l o o r}=\quad 0 \quad s f \\
& S A_{A C I D}=0 \\
& S A_{T-W a l l}=2898 \mathrm{sf} \\
& S A_{T-\text { Roof }}=1671 \mathrm{sf} \\
& S A_{\text {T-Floor }}=1671 \text { sf } \\
& r_{M E T H}=\sqrt{\frac{V_{M E T H}}{\pi \times h_{M E T H}}} \\
& h=20 \mathrm{ft} \\
& r_{\text {METH }}=\sqrt{\frac{250,000 \mathrm{gal}}{\pi \times 20 \mathrm{ft} \times 7.48 \frac{g a l}{c f}}} \\
& r_{\text {METH }}=23.1 \mathrm{ft} \\
& S A_{M E T H}=6241
\end{aligned}
$$




\section{References}

All Star Technical Services, Inc. July 2012. Anaerobic Digester Membrane Cover Investigation and Report, Digester Membrane Cover Assessment, Fort Huachuca, AZ. Contract report to Fort Huachuca DPW. San Diego, CA: All Star Technical Services.

Arsova, L. May 2010. Anaerobic Digestion of Food Waste: Current Status, Problems, and an Alternative Product. Master's thesis for Department of Earth and Environmental Engineering. New York, NY: Columbia University.

ASIP. 2017. Authorized user to query the latest official ASIP data. Retrieved 16 Feb. 2017 from https://asip.hqda.pentagon.mil/default_asip/default.htm.

ASTM D5231, "Standard Test Method for Determination of the Composition of Unprocessed Municipal Solid Waste.” Conshohocken, PA: ASTM International.

Bond, T., C.J. Brouckaert, K.M. Foxon, and C.A. Buckley. 2012. "A Critical Review of Experimental and Predicted Methane Generation from Anaerobic Co-Digestion.” Water Science and Technology 65(1): 183-189.

Chapman, T. and C. Muller. 2010. "Impact of Series Digestion on Process Stability and Performance." In Proceedings of the Water Environment Federation, Residuals and Biosolids, 167-178(12).

Executive Order 13693. 19 March 2015. "Planning for Federal Sustainability in the Next Decade.” Washington, DC: Office of President Barack Obama.

Ghosh, Sambhunath, John R. Conrad, and Donald L. Klass. 1975. "Anaerobic Acidogenesis of Wastewater Sludge.” Journal of the Water Pollution Control Federation 47(1): 30-45.

Ma, Anthony Y.W., Billy K.W. Cheung, Katrina C.M. Kwok, Mingwei Cai, and Patrick K.H. Lee. 2016. "Recent Advances of Anaerobic Digestion for Energy Recovery." In Recycling of Solid Waste for Biofuels and Bio-chemicals, edited by O.P. Karthikeyan et al., 87-126. Singapore: Springer Science+Business Media.

Natural Systems Utilities. 2014 (rev. 2015). “Anaerobic Digestion and Biogas.” Revision 4 of Ebook, available at www.digester.com. Hillsborough Township, NJ: Natural Systems Utilities.

Turovskiy, I. S., and P.K. Mathai. 2006. “Anaerobic Digestion.” Chapter 5 in Wastewater Sludge Processing. New York: John Wiley \& Sons.

U.S. Army. 2009. "Army Stationing and Installation Plan (ASIP)." Army Regulation AR5-18. Washington, DC: Headquarters, Department of the Army.

. 2011. "Army Vision for Net Zero." White paper. Washington, DC: Office of the Assistant Secretary of the Army for Installations, Energy \& Environment (ASA(IE\&E)), Department of the Army. 
. 2014. "Net Zero Installations Policy.” Army Directive 2014-02. Washington, DC: Secretary of the Army.

. 29 September 2014. Sustainability Report 2014: Sustain the Mission, Secure the Future. Washington, DC: Office of the Assistant Secretary of the Army for Installations, Energy \& Environment (ASA(IE\&E)), Department of the Army.

U.S. EPA. 1999. "Standards for the Use or Disposal of Sewage Sludge." 58 Federal Register(FR) 9387, as amended at 64 FR 4268.

.2008. U.S. EPA Clean Watershed Needs Survey. Washington, DC: U.S. EPA.

September 2014. Food Waste to Energy: How Six Water Resource Recovery Facilities are Boosting Biogas Production and the Bottom Line. EPA 600/R14/240. Washington, DC: U.S. EPA Office of Research and Development.

. October 2015. Anaerobic Digestion and its Applications. EPA 600/R15/304. Washington, DC: U.S. EPA Office of Research and Development. 


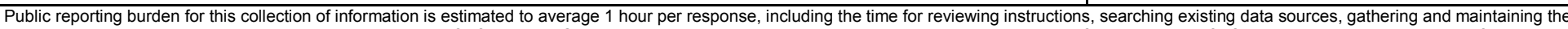

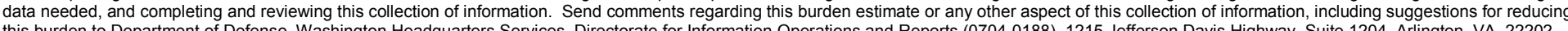

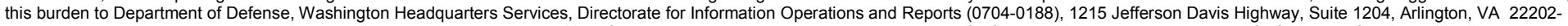

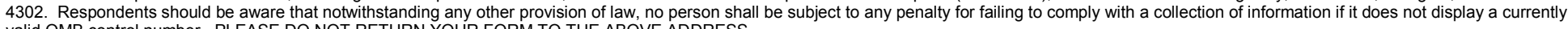
valid OMB control number. PLEASE DO NOT RETURN YOUR FORM TO THE ABOVE ADDRESS.
1. REPORT DATE (DD-MM-YYYY) March 2017

\section{REPORT TYPE}
3. DATES COVERED (From - To)

\section{TITLE AND SUBTITLE}

Feasibility Study of Food Waste Co-Digestion at U.S. Army Installations
Final

5a. CONTRACT NUMBER

5b. GRANT NUMBER

5c. PROGRAM ELEMENT NUMBER

5d. PROJECT NUMBER

455592

5e. TASK NUMBER

5f. WORK UNIT NUMBER

8. PERFORMING ORGANIZATION REPORT NUMBER

ERDC/CERL TR-17-7

\section{Construction Engineering Research Laboratory (CERL)}

U.S. Army Engineer Research and Development Center (ERDC)

PO Box 9005

Champaign, IL 61826-9005

\section{SPONSORING / MONITORING AGENCY NAME(S) AND ADDRESS(ES)}

Assistant Secretary of the Army for

Installations, Energy and Environment

110 Army Pentagon

Washington, DC 20314-1000

10. SPONSOR/MONITOR'S ACRONYM(S) ASA(IE\&E)

11. SPONSOR/MONITOR'S REPORT NUMBER(S)

12. DISTRIBUTION / AVAILABILITY STATEMENT

Approved for public release. Distribution is unlimited.

\section{SUPPLEMENTARY NOTES}

\section{ABSTRACT}

Army Net Zero is a comprehensive approach to preserve natural resources by focusing on energy, water, and waste at Army installations. Army Directive 2014-02, "Net Zero Installations Policy" set policy and assigned responsibility to strive toward Net Zero at all Army installations, wherever fiscally responsible. As part of its greater vision of strategic sustainability, Fort Huachuca, Arizona, seeks to meet Army Net Zero objectives.

The Wastewater Treatment Plant (WWTP) at Fort Huachuca is the focus of the net zero waste project discussed here. The U.S. Army Engineer Research and Development Center-Construction Engineering Research Laboratory (ERDC-CERL), with collaboration from the U.S. Environmental Protection Agency designed a study to evaluate the feasibility of food waste co-digestion at Fort Huachuca. The study was designed to (1) reduce the amount of organic material going to landfill, (2) reduce greenhouse gas emissions, and (3) produce renewable energy. From this work, team members concluded that co-digestion of food and biosolids would be a win-win scenario for Fort Huachuca because it would help eliminate the largest part of the waste stream (food), reduce biosolids disposal costs, and generate power for operating the installation's WWTP.

\section{SUBJECT TERMS}

Sustainable engineering, Military bases, Food waste, Sewage--Purification--Anaerobic treatment, Biogas

\section{SECURITY CLASSIFICATION OF:}

\section{a. REPORT} Unclassified

\section{b. ABSTRACT} Unclassified

17. LIMITATION
OF ABSTRACT
UU

\begin{tabular}{c|c} 
18. NUMBER \\
OF PAGES
\end{tabular}

19a. NAME OF RESPONSIBLE PERSON

19b. TELEPHONE NUMBER (include area code) 